UNIVERSIDADE DE SÃO PAULO

Escola de Engenharia de São Carlos

Departamento de Arquitetura e Urbanismo

\title{
Memória e patrimônio cultural em ambientes virtuais
}

RODRIGO PERONTI SANTIAGO

orientadora: Profa. Dra. Anja Pratschke 
RODRIGO PERONTI SANTIAGO

\title{
MEMÓRIA E PATRIMÔNIO CULTURAL EM AMBIENTES VIRTUAIS
}

\author{
Dissertação аргesentada ao ргоgrama de Pós- \\ Graduação em Arquitetura e Urbanismo, Escola de \\ Engenharia de São Carlos, Universidade de São \\ Paulo, рага a obtenção do Título de Mestre em \\ Arquitetura.
}

Área de concentração: Teoria e História da Arquitetura e Urbanismo

Orientadora: Рrofa. Dra. ANJA PRATSCHKE 
AUTORIZO A REPRODUÇÃO E DIVULGAÇÃO TOTAL OU PARCIAL DESTE TRABALHO, POR QUALQUER MEIO CONVENCIONAL OU ELETRÔNICO, PARA FINS DE ESTUDO E PESQUISA, DESDE QUE CITADA A FONTE.

Ficha catalográfica preparada pela Seção de Tratamento da Informação do Serviço de Biblioteca - EESC/USP

$\mathrm{s} 235 \mathrm{~m}$ Santiago, Rodrigo Peronti Memória e patrimônio cultural em ambientes virtuais / Rodrigo Peronti Santiago ; orientadora Anja Pratschke . - São Carlos, 2007.

Dissertação (Mestrado) - Programa de Pós-Graduação em Arquitetura e Urbanismo e Área de Concentração em Teoria e História da Arquitetura e do Urbanismo -- Escola de Engenharia de São Carlos da Universidade de São Paulo.

1. Tecnologia de informação e comunicação. 2 . Preservação. 3. Patrimônio cultural. 4. Memória coletiva. 5. Mídia digital. I. Título. 


\section{Memória}

Amar o регdido deixa confundido este согас̨ão.

Nada pode o olvido contra o sem sentido apelo do Não.

As coisas tangiveis †огnam-se insensíveis à palma da mão.

Mas as coisas findas, muito mais que lindas, essas ficarão. 
"...and, in the end, the love you take is equal to the love you make." John Lennon/Paul McCartney, 1969.

\section{Agradecimentos}

Às pessoas e instituições que contribuíram рага a realização desse trabalho, além daquelas que adicionaram, nesses anos de mestrado, a minha formação como pesquisador e pessoa. Muito obrigado!

Azael Rangel Camargo, Camila Souza Регеira, Chan Hua Xin, Daniel Mazziero, Evandro César Bueno, Fernanda Januário Borba, Fundação Pró-Memória de São Carlos, Fundação Educacional de São Carlos, Instituto do Patrimônio Histórico e Artístico Nacional, José Ricardo Rosolen, Lisandra Casagrande, Luzia Sigoli, Marcelo Tramontano, Maria Angela Bortolucci, Memória Votorantim, Nilton César Nardelli, Nomads.usp, Pablo de Caldas Paulse, Pedro Cornetta, Rodrigo Firmino, Varlete Benevente, Ulpiano Toledo Bezerra de Meneses, Vera Dodebei e Wilson Roberto Fеггеіга Santiago.

Agradeço especialmente a minha orientadora, professora Anja Pratschke, pela dedicação, e à FAPESP- Fundação de Amparo à Pesquisa do Estado de São Paulo, pelo apoio fundamental. 


\section{Resumo}

SANTIAGO, R.P. (2007). Memória e patrimônio cultural em ambientes virtuais. 2007. 150p. Dissertação (Mestrado). Escola de Engenharia de São Carlos, Universidade de São Paulo, São Carlos, 2007.

Discute, tendo como cenário o atual ambiente tecnológico baseado na mídia digital, as potencialidades do emprego das chamadas Tecnologias de Informação e Comunicação na preservação do patrimônio cultural e no desenvolvimento da memória coletiva contemporânea, além de contribuir para a construção de um referencial teórico sobre o tema. Inicialmente conceitua patrimônio, memória e mídia, fazendo uma ligação entre eles. Em um segundo momento, aprofunda na discussão sobre modos de tradução de bens culturais para ambientes virtuais, estabelecendo possíveis critérios de abordagens de projetos dessa natureza, que serão aplicados, ao final da dissertação, na análise de uma dessas experiências.

Palavras-chave: Tecnologia de informação e comunicação. Preservação. Patrimônio cultural. Memória coletiva. Mídia digital.

\section{Abstract}

SANTIAGO, R.P. (2007). Memory and cultural heritage in virtual environments. 2007. 150p. Dissertação (Mestrado). Escola de Engenharia de São Carlos, Universidade de São Paulo, São Carlos, 2007.

It is discussed, in the scenery of the actual technological environment based on the digital media, the potencials of the so called Information and Communications Technology in the cultural heritage preservation and in the contemporary collective memory developing, and also contributes to a theoretical referencing construction about the theme. First heritage, memory and media is contextualized, establishing relations between them. In a second moment, a discussion about translation forms of cultural goods to virtual environments is realized, establishing possible criterias for approaching projects of this nature that will be applied, at the end of this dissertation, in the analysis of one of these experiences.

Keywords: Information and Communications Technology. Preservation. Cultural heritage. Collective memory. Digital media. 
Introdução 07

\begin{abstract}
capítulo 113
Conceitos emergentes:

patrimônio cultural, memória social e meios

de comunicação.
\end{abstract}

151.10 patrimônio cultural

221.2 A memória social

271.3 A mídia e a comunicação

301.4 Os meios de comunicação na construção da memória social e na preservação do patrimônio cultural

32 1.4.1 Memória e patrimônio e a mnemosfera

33 1.4.2 Memória e patrimônio e a logosfera

38 1.4.3 Memória e patrimônio e a grafosfera

43 1.4.4 Memória e patrimônio e a videosfera

451.4 .5 A videosfera: formação e características

47 1.4.6 A emergência do espaço virtual

49 1.4.7 A emergência do espaço híbrido ou mesclado

511.5 Considerações

562.1 A comunicação

692.2 A virtualização

822.3 Os sistemas

902.4 Considerações

\section{capítulo 393}

Análise: curso de extensão PinhalDigital.

983.1 PinhalDigital - de workshop a curso de extensão: difusão

1073.2 A comunicação no curso PinhalDigital

1133.3 A virtualização no curso PinhalDigital

1173.4 Os sistemas no curso PinhalDigital

1193.5 Considerações 
Introdução 
Рага Chardin [1995], a vida consiste essencialmente em ver. Segundo o autor, podemos dizer que a história do mundo é a história da elaboração de olhos cada vez mais perfeitos através dos quais é possível discernir cada vez mais, conhecer cada vez mais. "Ver ou perecer. Tal é a situação imposta pelo dom misterioso da existência a tudo quanto é elemento do Universo. E tal é, рог conseqüência, num grau superior, a condição humana" [CHARDIN, 1995, p.5].

Essa dissertação de mestrado em Arquitetura e Urbanismo tem como objetivo ргосигаг vег е compreender, em uma perspectiva ampliada, o papel do arquiteto frente às potencialidades do emprego das chamadas Tecnologias de Informação e Comunicação, baseadas na mídia digital, especificamente em relação à preservação do patrimônio cultural e à construção da memória coletiva, assim como estabelecer critérios de análise de projetos relacionados a esse tema.

A pesquisa tem como pano de fundo as reflexões a respeito do atual ambiente tecnológico, resultante de um movimento de convergência entre mídia, computação e telecomunicações - os produtos diretos da chamada "Revolução Informacional" do século XX, que acelerou-se, sobretudo, na década de 1970, como observou o sociólogo Manuel Castells [1999].

Esse trabalho foi inicialmente motivado pelos estudos da pesquisadora Anja Ргatschke, nossa orientadora, рrofessora do Departamento de Arquitetura e Urbanismo da Universidade de São Paulo, campus de São Carlos, acerca das novas atribuições profissionais do arquiteto frente a esse novo ambiente tecnológico, caracterizado pelo uso crescente da mídia digital e pela emergência de novas espacialidades, como a virtual e, mais recentemente, a mesclada ou híbrida, essa última constituída pela combinação de espaços concretos e virtuais.

A pesquisadora, em suas reflexões na tese de doutorado "Entre mnemo e locus: arquitetura de espaços virtuais, construção de espaços mentais" [2002], fez uma aproximação entre os métodos de design na arquitetura e computação, defendendo que o arquiteto, tradicionalmente visto como o construtor do espaço concreto, por sua formação multidisciplinar seria também um dos profissionais mais aptos na reflexão e construção do espaço virtual, entendido como produto de um esforço também 
multidisciplinar. Dessa forma, "рог гаzões principalmente metodológicas, e não estéticas como se costuma afirmar" [PRATSCHKE, TRAMONTANO, MOREIRA, 2000, p.4], esse organizador do ambiente físico, seria chamado agora também à organização da espacialidade virtual.

Tendo em mente essas verificações como ponto de partida, nos propusemos então a dar um passo além, ргоcurando compreender de que modo poderia se dar a organização do virtual, tendo como objeto específico de estudo questões relacionadas à ргеservação do patrimônio cultural, um tema tradicionalmente pertencente, por séculos, ao campo de reflexões da Arquitetura.

A vontade de olhar especificamente para experiências ligadas a mídia digital e patrimônio cultural nasceu, em grande parte, a partir de nosso envolvimento com o curso de extensão universitária PinhalDigital: Processos multimídia nas Fazendas de Café: história, arquitetura e tecnologia. 0 objetivo do curso, em linhas gerais, foi a ргеservação de bens culturais da Fazenda Pinhal, um importante conjunto rural tombado pelo Instituto do Patrimônio Histórico e Artístico Nacional (IPHAN), através do emprego das tecnologias informacionais, objetivando-se a divulgação do acervo lá presente, o que contribuiria рага a construção da memória local referente à cidade de São Carlos e гegião.

Após o contato com o curso, toda nossa atividade acadêmica e de pesquisa voltou-se ao entendimento de uma possível relação entre patrimônio e mídia. Iniciamos, assim, coletas de bibliografias relacionadas ao tema, ao mesmo tempo em que participamos de palestras, encontros, simpósios e congressos, entrando em contato direto com profissionais selecionados larquitetos, artistas, cineastas, designers, cientistas da computação, entre outros) atuantes na área do tema da pesquisa. Dessa forma, fomos construindo o referencial teórico em que se baseia essa dissertação de mestrado, formado рог um conjunto multidisciplinar de autores de áreas como arquitetura, filosofia, história, sociologia, comunicação e ciência da computação.

Com o desenvolvimento do trabalho diversas perguntas surgiram. Antes mesmo de estabelecermos pontos de contato entre patrimônio e mídia, como se relacionaria patrimônio cultural e memória social? De que maneira os meios de comunicação 
anteriores à mídia digital também contribuíram para a construção da memória social? Como o chamado pensar digital, caracterizado, sobretudo, pela não-linearidade, virtualização e interação, орегando рог formas distintas das outras mídias poderia ampliar o entendimento do patrimônio cultural? E, por fim, quais os possíveis critérios de análise de experiências que propõem o emprego das tecnologias informacionais como meio de preservação de bens culturais?

Ргоcurando responder a tais questionamentos, essa dissertação é organizada em três capítulos, além da introdução e conclusão.

0 Capítulo 1, denominado Conceitos emergentes: patrimônio cultural, memória social e meios de comunicação, ргосura definir os conceitos relativos a patrimônio cultural, memória coletiva ou social e comunicação e mídia que norteiam todo o trabalho, estabelecendo, em um segundo momento, pontos de contato entre eles. Рага isso, apresentamos a história da constituição da noção do patrimônio cultural, nos baseando nas chamadas Cartas patrimoniais editadas ao longo do século XX e início do século XXI; conceituamos a memória social ou coletiva, e sua relação com o patrimônio cultural; e por final, realizamos uma discussão em torno da construção e evolução da memória social segundo os meios de comunicação empregados em cinco momentos da história humana: 1) nas sociedades sem escrita; 2) na Pré-História à Antigüidade, com a invenção do alfabeto fonético; 3) na Idade Média, quando há um equilíbrio entre da tradição oral e a escrita; 4) no século XV com a invenção da imprensa; e 5) com os desenvolvimentos das mídias eletrônicas.

0 Capítulo 2, denominado Patrimônio cultural, memória social e mídia digital, trata de aspectos mais diretamente ligados à tradução de bens culturais para a mídia digital e às espacialidades virtual e mescladas, que envolvem um processo que implica em ações visando a vinculação do patrimônio e memória coletiva às Tecnologias de Informação e Comunicação. Nesse contexto, аргesentamos três possíveis abordagens рага que essas ações se viabilizem, inicialmente indicadas pelo pesquisador Ulpiano $T$. Веzегга de Meneses: 1) o modo de como a questão da comunicação deve ser contemplada dentro desse processo no que refere-se à relação usuário-interface gráfica à relação usuário-tecnologias informacionais; 2) o entendimento do significado da 
virtualização dos bens culturais; e 3) a concepção de sistemas que visam a orientação a novas formas aquisição de conhecimento do patrimônio.

0 Capítulo 3, denominado Análise: curso de extensão PinhalDigital, apresenta em detalhes a experiência do curso de extensão universitária PinhalDigital: Processos multimídia nas Fazendas de Café: história, arquitetura e tecnologia, que tem como objetivo central o entendimento рог múltiplos olhares do patrimônio cultural гuгal de uma importante fazenda do ciclo cafeeiro do século XIX, no interior do estado de São Paulo - a Fazenda Pinhal -, através do emprego de tecnologias informacionais. Analisando sua metodologia, organização e produtos, realizamos então uma proposta de revisão, segundo métodos de análise baseados na comunicação, na virtualização e nos sistemas, extraídos dos capítulos anteriores.

E as Considerações finais apresentam os limites da pesquisa, um panorama geral dos assuntos abordados na dissertação e os resultados obtidos, indicando também caminhos para trabalhos futuros.

Аргesentando-se dessa maneira, essa dissertação, partindo de aspectos mais gerais, vai, no desenvolvimento de suas reflexões, circundando o objeto de estudo, até seu detalhamento, pretendendo, assim, contribuir efetivamente рага as discussões sobre memória e patrimônio cultural em ambientes virtuais. 


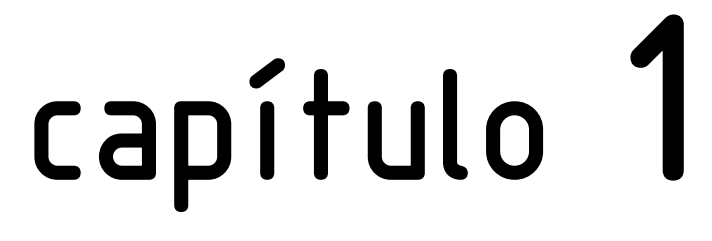

CONCEITOS EMERGENTES: o patrimônio cultural, a memória social e os meios de comunicação 
"There is no past that one is allowed to long for. There is only the eternally new, growing from enlarged elements of the past; and genuine longing always must be productive must create some thing NEW and BETTER."

Johann Wolfang Goethe

0 ргеsente capítulo tem como objetivo fundamentar teoricamente essa dissertação. Serão aqui apresentados e discutidos diversos conceitos, sempre apoiados na reflexão de um conjunto de importantes autores, alguns deles já clássicos, que abordaram em seus estudos temas relacionados a três universos: o patrimônio cultural, a memória social e os meios de comunicação.

Ao final da discussão desses três temas, ргоcuraremos estabelecer relações de contato entre tais universos, visando compreender de que maneira os meios de comunicação foram sendo empregados na construção da memória social e na ргеservação do patrimônio cultural ao longo dos séculos. Nossas investigações serão realizadas em quatro momentos da história da mídia: no período anterior à invenção do alfabeto fonético; no momento de convívio entre oralidade e escrita; па ега dos impressos e па ега das mídias eletrônicas. Realizados tais estudos, acreditamos que teremos preparado o caminho рага um aprofundamento de tal reflexão contemporaneamente, após o advento das Tecnologias de Comunicação e Informação, baseadas na mídia digital, que осоггегá no capítulo 2.

\subsection{0 patrimônio cultural}

Patrimônio. Esta bela e antiga palavra estava, na origem, ligada às estruturas familiares, econômicas e jurídicas de uma sociedade estável, enraizada no espaço e no tempo. Requalificada por diversos adjetivos (genético, natural, histórico, etc.) que fizeram dela um conceito nômade, ela segue hoje uma tгajetória diferente e retumbante [CHOAY, 2001, p.11]. 
As palavras da historiadora Françoise Choay resumem bem a evolução pela qual tem passado o termo patrimônio ao longo dos tempos. Expandindo-se semanticamente, essa palavra que, segundo a clássica definição de Littré [1872], significa um "bem de herança que é transmitido, segundo leis, dos pais e das mães aos filhos"1, foi tomando novos contornos à medida em que foi sendo empregada em diferentes contextos, em diferentes momentos. Nosso foco aqui é seu emprego atrelado ao adjetivo histórico, cuja união resultou em uma

expressão que designa um bem destinado ao usufruto de uma comunidade que se ampliou a dimensões planetárias, constituído pela acumulação contínua de uma diversidade de objetos que se congregam por seu passado comum: obras e obras-primas das belas artes e das artes aplicadas, trabalhos e produtos de todos os saberes e savoir-faire dos seres humanos [CHOAY, 2001, p.11].

Tal dimensão planetária alcançada em nossos dias pelo patrimônio histórico é produto de sua evolução para o conceito de "patrimônio cultural" nas últimas décadas do século passado [ORGANIZAÇÃO DAS NAÇÕES UNIDAS PARA A EDUCAÇ̃̃O, CIÊNCIA E CULTURA - UNESC0, 2007]. Hoje, nos primeiros anos do século XXI, após o surgimento das chamadas Tecnologias de Informação e Comunicação, o patrimônio parece mais uma vez expandir-se em direção a novas formas de entendimento e meios de sua ргеservação.

Рага 0 entendimento dessas novas possibilidades, acreditamos ser de fundamental importância sua compreensão contemporânea. Embora essa seja resultado de uma longa evolução ${ }^{2}$, o recorte temporal que fixamos é seu desenvolvimento durante - século XX aos dias atuais, quando, pela ргіmeira vez se estabeleceram геgгas aceites internacionalmente tendo em vista solucionar os problemas complexos de sua salvaguarda, e também рог se tratar do momento de formação do "atual ambiente

\footnotetext{
1 Dictionnarie de la langue française de É. Littré. Definição de patrimônio traduzida por Luciano Vieira Machado.

2 Choay [2001] estabelece como o início da formação da noção de patrimônio cultural a afeições de civilizações antigas por obras do passado, que, todavia, ainda não se prendiam a sua relação com uma história à qual conferissem autenticidade ou permitissem datar, nem à sua antiguidade. Tal afeição ocorreria porque estas obras davam a conhecer as realizações de uma civilização superior. Como marco inicial desse interesse, o estudioso J. Alsop [1982] posiciona procura fervorosa dos atálidas, uma civilização localizada próxima ao mar Egeu, por esculturas e objetos de arte decorativa produzidos na Grécia Antiga. Pouco tempo depois, os objetos que encantaram esse povo, começariam também a provocar interesse aos romanos, que os espoliaram durante as conquistas de antigos territórios gregos.
} 
tecnológico" [CASTELLS, 1999], que hoje рагесе oferecer novas maneiras рага sua leitura.

Conforme consta na coletânea de documentos relativos ao patrimônio cultural, editada pelo Instituto do Patrimônio Histórico e Artístico Nacional - IPHAN [2004], a ргіmeira conferência internacional рага a conservação de monumentos históricos, ocorreu em Atenas, em 1931, promovida pela Sociedade de Nações. 0 produto dessa conferência foi a primeira das Cartas Patrimoniais editadas no século $X X$, que configuram-se como "documentos, muitos dos quais firmados internacionalmente, que гергеsentam tentativas que vão além do estabelecimento de normas e procedimentos, criando e circunscrevendo conceitos às vezes globais, outras vezes locais", [IPHAN, 2004, p.7] nas quais se baseariam as políticas de preservação de monumentos históricos de vários países.

Isabelle Сuгу, огganizadora da coletânea do IPHAN, observa que "nas primeiras carłas, fica clara a ргеocupação em definir a própria noção de monumento e de seu entorno" [IPHAN, 2004, p.10]. A influência desses primeiros documentos foi muito importante sobre as pesquisas relacionadas ao tema nas primeiras décadas do século passado, podendo, рог exemplo, ser notada em documentos de trabalho relativos a tombamentos ${ }^{3}$ do arquiteto Lucio Costa, um dos estudiosos que mais contribuiu рага sua conceituação no Brasil. 0 arquiteto invocava o monumento histórico como um "passado válido", indispensável à construção de uma memória coletiva, um vínculo simbólico, capaz de manter de algum modo viva, no espírito dos cidadãos, a consciência da continuidade que os une a todos, de geração em geração [COSTA; PESSOA, 2004].

Seguindo essa mesma característica definidora, em 1933 redigiu-se uma segunda Carta de Atenas, no entanto produzida durante o IV Congresso Internacional de Arquitetura Moderna (CIAM). Tendo como tema central a cidade funcional [FRAMPTON, 1997], sua seção dedicada à proteção de bens históricos, dizia:

\footnotetext{
3 Documentos referentes ao período entre 1937 e 1972, em que Lucio Costa foi diretor da Divisão de Estudos e Tombamentos do Serviço do Patrimônio Histórico e Artístico Nacional (SPHAN), atual Instituto do Patrimônio Histórico e Artístico Nacional (IPHAN). Após sua aposentadoria, em 1972, o arquiteto continuou atuando como consultor do órgão até praticamente sua morte, em 1998.
} 
A vida de uma cidade é um acontecimento contínuo, que se manifesta ao longo dos séculos рог obras materiais, traçados ou construções que the conferem sua personalidade própria e dos quais emana pouco a pouco sua alma. São testemunhos preciosos do passado que serão respeitados, a princípio por seu valor histórico ou sentimental, depois porque alguns trazem uma virtude plástica na qual se incorporou o mais alto grau de intensidade do gênio humano [CIAM IV, 1933].

Sublinhamos nessa definição a referência às obras materiais. Verificamos que, a princípio, nos primeiros textos que tratavam do patrimônio histórico, esse ега entendido apenas como um bem material e basicamente como uma obra arquitetônica. Essa compreensão, segundo Le Goff [2006], рагеce vir da própria origem da palavra monumento e da expressão monumento histórico, que estão na gênese da idéia de patrimônio cultural. o termo monumento, do latim monumentum, derivou-se, na Antigüidade Clássica, de monere ("advertir", "lembrar"), isto é, aquilo que traz à lembrança alguma coisa. Choay [2001] observou que em Roma, no ano de 1420, com 0 desenvolvimento de um clima intelectual em torno de ruínas antigas que falavam da história e confirmavam o passado fabuloso da cidade que se ргеtendia гесuperar, esse ligou-se ao adjetivo histórico, sendo a partir de então entendido como obras агquitetônicas remanescentes de épocas passadas.

0 artigo primeiro do Decreto-Lei que criou no Brasil, em 1937, o Serviço do Patrimônio Histórico e Artístico Nacional (SPHAN), atual Instituto do Patrimônio Histórico e Artístico Nacional (IPHAN), também confirmaria essa visão, declarando que são essencialmente os bens materiais, sejam eles móveis ou imóveis", o patrimônio histórico do país. Segundo o Decreto-Lei:

Art. 10 Constitui o patrimônio histórico e artístico nacional o conjunto dos bens móveis e imóveis existentes no país e cuja conservação seja de interesse público, quer рог sua vinculação a fatos memoráveis da história do Вrasil, quer рог seu excepcional valor arqueológico ou etnográfico, bibliográfico ou artístico [Decreto-Lei no 25, de 30/11/1937].

Esse entendimento ainda restrito, no entanto, começaria a mudar no período entre o fim da II Guerra Mundial e os anos 1960. Choay [2001, p.12] comentou:

\footnotetext{
"São bens imóveis: núcleos urbanos, sítios arqueológicos e paisagísticos e bens individuais; são bens móveis: coleções arqueológicas, acervos museológicos, documentais, bibliográficos, arquivísticos, videográficos, fotográficos e cinematográficos [IPHAN, 2007].
} 
A partir da década de 1960, os monumentos históricos já não гергesentam senão parte de uma herança que não pára de crescer com a inclusão de novos tipos de bens e com o alargamento do quadro cronológico e das áreas geográficas no interior das quais esses bens se inscrevem.

o alargamento do universo de bens a serem protegidos e sua natureza referem-se, como observou Fonseca [1997], à introdução nos patrimônios da produção dos "esquecidos" pela história factual, mas que passaram a ser objeto principal de interesse da história das mentalidades: os operários, os camponeses, os imigrantes, as minorias étnicas, entre outros. Aos bens referentes a esses grupos se acrescentaram os produtos da ега industrial e os remanescentes do mundo ruгal. No Bгasil, o caso da literatura de cordel ilustra de modo interessante esse fato. Essa foi uma literatura surgida na segunda metade do século XIX no nordeste bгasileiro, ргoduzida рог poetas populares рага ser vendida em feiras e mercados pendurada em barbantes - sua denominação vem dessa forma de exposição à venda. Profundamente enraizada em tradições rurais, o cordel "envolve mais um significado coletivo em jogo: o valor de 'autenticidade' e 'genialidade' сriadora das comunidades e dos lideres e mestres locais que incorporam e atualizam um conjunto de memórias" [ALVES, 2007, p.08]. Dada sua importância, tal literatura atualmente passa рог um ргоcesso registro ${ }^{5}$ pelo IPHAN como bem cultural imaterial, que é uma nova classificação de patrimônio que discutiremos mais adiante.

A esse alargamento de universo dos bens a serem protegidos, somou-se uma maior abrangência geográfica, principalmente a partir da criação da Organização das Nações Unidas para a Educação, a Ciência e a Cultura (UNESCO) em 1945, que, рага Fonseca [1997], foi o grande marco na proteção e preservação de bens de valor histórico em âmbito internacional.

A respeito desses novos limites geográficos, observamos que na Conferência de Atenas, em 1931, promovida pela Sociedade de Nações, só participaram europeus. Em

\footnotetext{
5 Conforme o Decreto Federal $n^{\circ} 3551 / 00$, a um bem cultural imaterial é somente aplicável o processo de registro que the confere essa condição especial. No entanto, esta pode ser perdida caso suas características sejam alteradas ao longo do tempo. Como trata-se de um bem abstrato, muito mais suscetível a mudanças que um bem material, tais características são examinadas a cada dez anos. Dessa forma, nunca um bem imaterial pode ser tombado, o que implicaria, segundo o art. 17 da Lei $n^{\circ} 25 / 37$, em assegurar sua proteção e preservação perpétua, sendo proibida expressamente sua destruição, demolição ou mutilação, sem prévia autorização especial do IPHAN.
} 
1964, na Conferência de Veneza, houve a participação de três países não-europeus: México, Tunísia e Peru. Já na Convenção de Paris, promovida pela UNESCO em 1972, oitenta países dos cinco continentes estavam presentes. Esse fato refletiu-se nos documentos de proteção produzidos a partir de então. Um exemplo são as chamadas Normas de Quito, uma carta redigida em 1967, durante a reunião sobre conservação e utilização de monumentos e sítios de interesse histórico e artístico da Organização dos Estados Americanos (OEA). Em um de seus trechos, o documento declarou a grande importância dos bens culturais americanos:

É uma realidade evidente que a América, em especial a América Ibérica, constitui uma região extraordinariamente rica em recursos monumentais. Os grandiosos testemunhos das culturas pré-colombianas se agregam as expressões monumentais, arquitetônicas, artísticas e históricas do extenso período colonial, numa exuberante variedade de formas [OEA, 1967].

Como resultado da maturação dos vários conceitos e observações presentes nas Cartas Patrimoniais editadas ao longo de todo século XX, a UNESCO produziu, em Paris, em 1972, com a participação de várias nações, como dissemos, a Convenção para a proteção do patrimônio mundial, cultural e natural. Esse documento foi um tratado internacional que reuniu um conjunto de dispositivos que trataram da identificação, a ргoteção e a preservação do patrimônio material, ou tangível de todo o mundo, considerado especialmente valioso para toda humanidade. Рог meio da Convenção, considerou-se patrimônio cultural:

Os monumentos. - Obras arquitetônicas, de escultura ou de pintura monumentais, elementos de estruturas de caráter arqueológico, inscrições, grutas e grupos de elementos com valor universal excepcional do ponto de vista da história, da arte ou da ciência;

Os conjuntos - Grupos de construções isoladas ou reunidos que, em virtude da sua arquitetura, unidade ou integração na paisagem têm valor universal excepcional do ponto de vista da história, da arte ou da ciência;

Os locais de interesse - Obras do homem, ou obras conjugadas do homem e da natureza, e as zonas, incluindo os locais de interesse arqueológico, com um valor universal excepcional do ponto de vista histórico, estético, etnológico ou antropológico [UNESC0, 1972].

Nessa definição, podemos verificar que a Convenção de 1972 ainda tratou apenas dos chamados bens materiais, que se compõem, segundo IPHAN [2007], 
por um conjunto de bens culturais classificados segundo sua natureza nos quatro Livros do Tombo: arqueológico, paisagístico e etnográfico; histórico; belas artes; e das artes aplicadas. Eles estão divididos em bens imóveis como os núcleos urbanos, sítios arqueológicos e paisagísticos e bens individuais; e móveis como coleções arqueológicas, acervos museológicos, documentais, bibliográficos, arquivísticos, videográficos, fotográficos e cinematográficos

Já no início desse século, em 2003, produziu-se um novo documento que complementaria a Convenção de Paris, de modo a contemplar, finalmente, toda a herança cultural da humanidade. Ele foi denominado de Convenção para a salvaguarda do patrimônio cultural imaterial, composto por um conjunto de dispositivos que trataram da identificação, proteção e preservação dessa nova categoria de bens.

Conforme a convenção, os bens imateriais ou intangíveis consistem em:

práticas, гергesentações, expressões, conhecimentos e técnicas e também os instrumentos, objetos, artefatos e lugares que thes são associados e as comunidades, os grupos e, em alguns casos, os indivíduos que se reconhecem como parte integrante de seu patrimônio cultural. Ele é transmitido de geração em geração e constantemente recriado pelas comunidades e grupos em função de seu ambiente, de sua interação com a natureza e de sua história, gerando um sentimento de identidade e continuidade, contribuindo assim рага ргоmover o respeito à diversidade cultural e à criatividade humana [UNESCO, 2003, p.03].

E, a partir de tal nova abrangência, mais universal, hoje o patrimônio cultural pode ser entendido como

- legado que recebemos do passado, vivemos no presente e transmitimos às futuras gerações (...) fonte insubstituível de vida e inspiração, nossa pedra de toque, nosso ponto de referência, nossa identidade, sendo de fundamental importância para a memória, a criatividade dos povos e a riqueza das culturas [UNESC0, 2007].

Assim, concluímos nossa reflexão acerca da construção da noção contemporânea de patrimônio cultural, que entendemos ser o primeiro passo para a compreensão das possíveis alterações em seu entendimento no momento em que esse pode ligar-se, com o advento das Tecnologias de Comunicação e Informação, à mídia digital. Resumindo o que foi tratado, propomos o esquema a seguir, visando facilitar a visualização de definições, às quais nos reportaremos freqüentemente ao longo de toda a dissertação. 


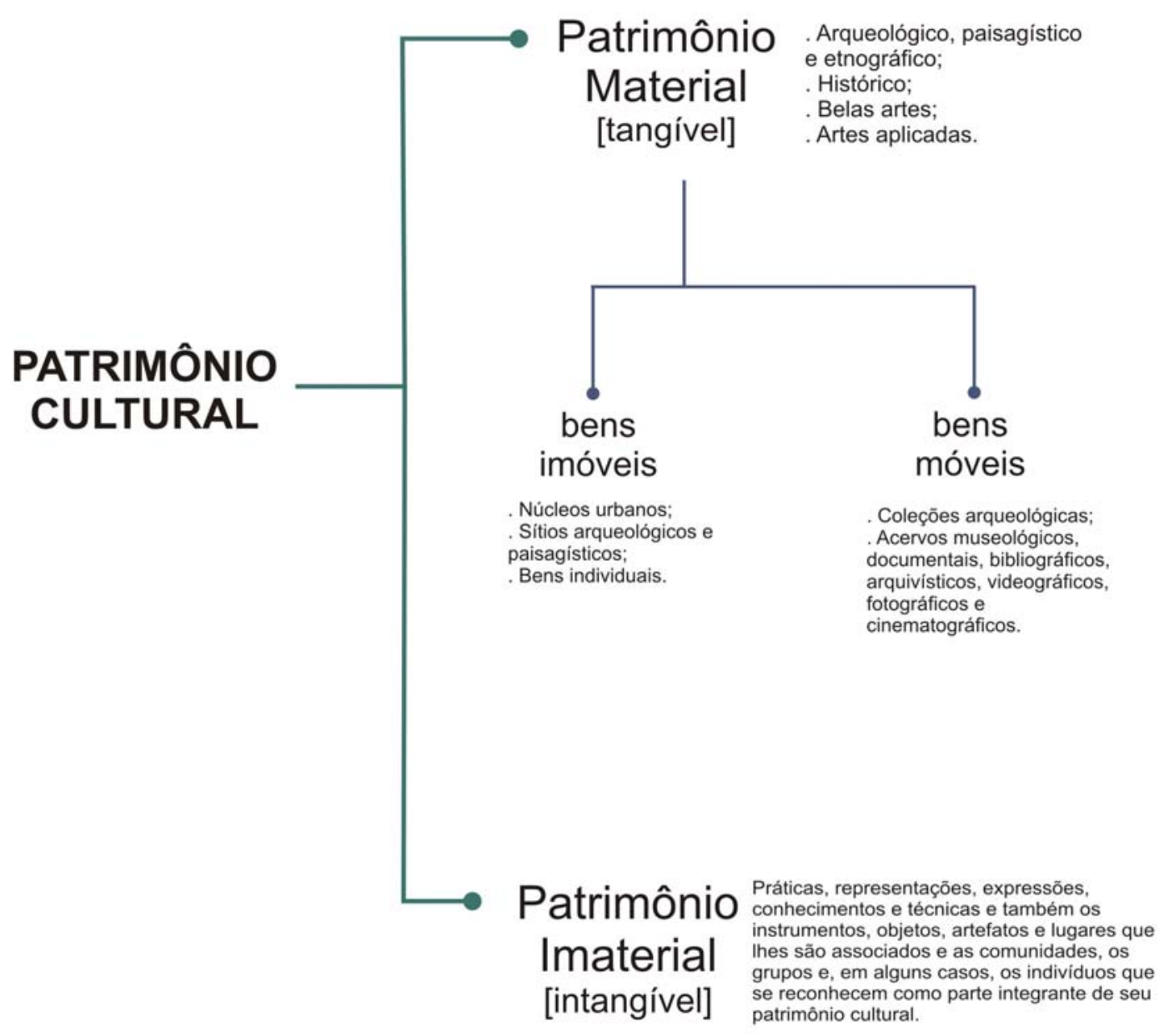

Fig. 1.1: Classificação contemporânea do patrimônio cultural.

\subsection{A memória social}

Algo freqüentemente observável quando se reflete sobre o patrimônio cultural, como foi visto no item anterior, é a aproximação que se faz de questões relativas à memória. A UNESCO [2007], em seus documentos produzidos sobre o tema, observa, рог exemplo, que os bens culturais são de "fundamental importância para a memória dos povos e a riqueza das culturas". Desse modo, entendemos que além de sua própria definição contemporânea, seja de suma importância a compreensão da relação desse e a memória, que nos ajudará em dois pontos: na compreensão da própria importância da ргеservação do patrimônio para a humanidade e como essa pode relacionar-se à mídia.

Começaremos essa investigação pela reflexão que Le Goff [2006, p.419] faz da memória humana. 0 autor comenta que ela, 
como propriedade de conservar certas informações, remete-se em primeiro lugar a um conjunto de funções psíquicas, graças às quais o homem pode atualizar impressões ou informações passadas, ou que ele representa como passadas (...) No entanto, além de um fenômeno individual e psicológico, a memória liga-se também à vida social.

Nesse trecho, Le Goff sublinha que a memória é também uma faculdade que extrapola um corpo ou um cérebro individual. A sociedade como um todo também seria possuidora de uma memória. Chamada nesse contexto de memória social ou coletiva, foco antigo de preocupações de pensadores como Nietzsche, Bergson e Freud, como observam Gondar e Dodebei [2005, p.8], essa modalidade de memória foi pela ргіmeira vez estudada de maneira mais rigorosa pelo sociólogo Maurice Halbwachs, no início do século XX. Em sua obra A memória coletiva, postumamente publicada em 1950, 0 sociólogo expôs que

as lembranças podem organizar-se de duas maneiras: tanto agrupando em torno de uma determinada pessoa, que as vê de seu ponto de vista, como se distribuindo dentro de uma sociedade grande ou pequena (...) Haveria motivos para distinguir duas memórias, que chamaríamos, por exemplo, uma interior ou interna, a outra exterior - ou então uma memória pessoal e a outra, memória social [HALBWACHS, 2006, p.73].

Сагаcterizando essa memória social ou coletiva, Gondar e Dodebei [2005] a apontam como um objeto de estudo transdisciplinar ${ }^{6}$, isto é, sua conceituação não seria possível de ser realizada a partir de um campo disciplinar específico. Seu conceito se encontraria em construção a partir de novos problemas resultantes do "entrecruzamento ou nos atravessamentos entre diferentes campos do saber" [GONDAR; DODEBEI, 2005, p.13]. Tais campos, para Le Goff [2006], seriam, por exemplo, a história, a antropologia, a psicologia, a sociologia, entre outros, mas a memória não se fixaria inteiramente em nenhum deles. "A memória não é a história, mas um de seus

\footnotetext{
6 A transdisciplinaridade visa articular uma nova compreensão da realidade entre e рага além das disciplinas especializadas. É uma abordagem que passa entre, além e através das disciplinas, numa busca de compreensão da complexidade. Рага o educador Jean Piaget, que no I seminário Internacional sobre pluri e interdisciplinaridade, realizado na Universidade de Nice, em 1970, divulgou pela primeira vez o termo, a transdisciplinaridade ргосuгa uma interação máxima entre as disciplinas porém respeitando suas individualidades, onde cada uma colabora para uma saber comum, o mais completo possível, sem transformá-las em uma única disciplina.
}

Segundo o artigo 3 da Carta da transdisciplinaridade, produzida pela UNESCO, em 1994:

"(...) a transdisciplinaridade não procura o domínio sobre várias outras disciplinas, mas a abertura de todas elas àquilo que as atravessa e as ultrapassa (...)" 
objetos e, simultaneamente, um nível elementar de elaboração histórica" [LE GOFF, 2006, p.49]. O historiador Рiегге Nora, no entanto, defende que a história teria uma natureza oposta à memória social.

Memória, história: longe de serem sinônimos, tomamos consciência de que tudo os opõe. A memória é vida e, por isso, está permanente evolução, aberta à dialética da lembrança e da amnésia, inconsciente de suas deformações sucessivas, vulnerável a todas as utilizações e manipulações, suscetível a longas latências e a súbitas revitalizações. A história é a reconstrução sempre problemática e incompleta do que não é mais. A memória é um fenômeno sempre atual, um fio vivido no presente eterno; a história, uma representação do passado (...) [NORA, 1993, p.9].

Contrapondo-a com a história, Nora vê a memória social como uma construção processual em constante evolução. Dessa maneira, não seria simplesmente a transmissão de legados entre gerações o meio pelo qual esta se constituiria. A memória social seria muito mais uma construção, baseada em contribuições de diversas gerações ao longo do tempo que seriam геinterpretadas e sofreria adições no presente. Sobre o fato, Gondar [2005, p.18] observa que a memória social

não nos conduz a reconstituir o passado, mas sim a reconstruí-lo com base nas questões que nos fazemos, que fazemos a ele, questões que dizem mais de nós mesmos, de nossa perspectiva presente, que do frescor dos acontecimentos passados.

Tais questões poderiam ser formuladas baseando-se em testemunhos, como comentou Halbwachs. Seu exemplo sobre o retorno de uma pessoa, após muitos anos, a uma cidade esclarece essa visão.

(...) quando voltamos a uma cidade em que já havíamos estado, o que percebemos nos ajuda a reconstituir um quadro de que muitas partes foram esquecidas. Se o que vemos hoje toma lugar no quadro de referências de nossas lembranças antigas, inversamente essas lembranças se adaptam ao conjunto de nossas percepções no presente. É como se estivéssemos diante de muitos testemunhos [HALBWACHS, 2006, p.29].

Halbwachs [2006] admitiu que o primeiro desses testemunhos seria sempre o nosso, aquele que carregamos conosco a partir de experiências pessoais, no entanto, poder-se-ia também basear-se em um conjunto de testemunhos alheios ou externos, formados рог lembranças coletivas ou, o que especialmente nos interessa aqui, a рагtir do contato e interpretação aos olhos atuais dos traços ou vestígios deixados pelo 
homem ao longo de sua existência (como certos aspectos da cidade nesse exemplo) e que estariam, ainda, presentes e ao nosso alcance. Esses vestígios seriam os chamados bens culturais materiais e imateriais que compõem o patrimônio cultural [UNESC0, 2007].

A relação entre memória social e patrimônio cultural se estabeleceria então desse modo. Os bens culturais teriam o poder de evocá-la e configurariam-se como espécies de externalizações dessa. Todavia, Le Goff [2006, p.525] alerta que tais bens, tomados como materiais remanescentes de outras épocas, não são o conjunto daquilo que existiu no passado, "mas o resultado de escolha efetuada quer pelas forças que operam no desenvolvimento temporal do mundo e da humanidade, quer pelos que se dedicam à ciência do passado e do tempo que passa, os historiadores". Assim o sendo, - autor alerta para o perigo da amnésia, que, segundo sua visão, não é só uma perturbação no indivíduo, que envolve alterações mais ou menos graves da presença da personalidade, mas também a falta ou a perda, muitas vezes voluntária, da memória coletiva de povos e nações, que pode determinar perturbações graves da identidade coletiva.

Os materiais remanescentes do passado, produto de um juízo de valores, que formariam o patrimônio cultural, são objetos potenciais de memória, onde essa pode se ancorar. "A memória se enraíza no concreto, no espaço, no gesto, na imagem, no objeto" [NORA, 1993, p.09], mas é importante ressaltar que "somente a atualização desses traços ou vestígios é que lhes poderá conferir o caráter de documento" [DODEBEI, 2005, p.43], que é o modo com que os materiais de memória se apresentam. Sobre tal fato, o neurofisiologista Jean-Paul Changeaux ${ }^{7}$ [1972, p.294, apud LE GOFF, 2006, p.420] comenta: "o processo da memória no homem faz intervir não só a ordenação dos vestígios, mas também a releitura desses vestígios" que é a sua atualização.

Dessa maneira, o patrimônio cultural e conseqüentemente a memória social não se tratam nunca da totalidade do passado, mas de frações escolhidas e reinterpretadas pelo presente. Além de tal característica, a memória social também

\footnotetext{
${ }^{7}$ CHANGEUX, J.-P (1972). Discussion a J.-P. Changeux e A. Danchin. Apprende par stabilisation sélective de synapses em cours de développement, in Morin e Piattelli Palmarini (orgs.), L'unité de l'homme. Invariants biologiques et universaux culturels. Paris: Senil. pp. 351-357.
} 
possuiria um caráter ficcional, que de cerła forma contribui para essa não totalidade. Halbwachs, citando Roustan ${ }^{8}$ [1930, apud HALBWACHS, 2006, p.43], escreveu "quando acreditamos evocar o passado há noventa e nove por cento de reconstrução e um por cento de evocação verdadeira". Então, podemos dizer que é impossível uma lembrança que reproduza exatamente um fato ocorrido. Nada garante que ela não é também constituída a partir de outras narrativas ou de uma criação imaginativa. 0 escritor argentino Jorge Luís Borges, cuja obra liga-se fortemente à temática da memória, vista por ele como uma articuladora da lembrança e do esquecimento, disse certa vez:

Nosso passado não é o que se pode registrar em uma biografia, ou o que podem ргорогсionar os jornais. Nosso passado é nossa memória. E essa memória pode ser uma memória latente, ou errônea, mas não importa: está aí. Pode mentir, mas essa mentira já é, então, parte da memória; é parte de nós [BORGES, 1990, p.34].

Do conjunto dessas reflexões, compreendemos por fim que patrimônio e memória relacionam-se à medida que os bens culturais, que constituem esse patrimônio, configuram-se como um suportes, externalizações, marcos ou pontos de apoio para ela. Visto que a memória social é uma reconstrução ou manifestação continuamente atualizada do passado, formada através de contribuições de diversas gerações ao longo do tempo, a interpretação do patrimônio cultural рог cada uma dessas gerações, converteria-se também em uma das maneiras de reconstrução ou atualização do passado.

Assim, entendemos que a importância da preservação do patrimônio cultural reside na ргópria ргеservação e evolução da memória social, "o legado de um povo, ligada diretamente à constituição da identidade nacional e cultural desse povo" [UNESCO, 2007]. Nesse ponto, estudiosos, como o historiador Peter Burke, dizem que os meios de comunicação ao longo dos tempos tiveram um papel fundamental nessa ргеservação e construção. O autor observa que a memória social, enraizada no patrimônio cultural e constituída em grande parte рог сriações imaginativas, foi sendo, ao longo de História da Humanidade, "influenciada pela organização social de †ransmissão e os diferentes meios de comunicação empregados" [BURKE, 2000, p.73]. Acreditamos que analisando essa influência, ao longo de toda história dos meios de

\footnotetext{
${ }^{8}$ ROUSTAN, D. (1930). La culture au tours de la vie. Pelman.
} 
comunicação, seja possível estabelecer as possíveis novas formas de construção da memória e preservação do patrimônio diante das tecnologias informacionais, baseadas na mídia digital, em nossos dias. No item a seguir ргосuгагеmos justamente refletir sobre essas questões.

\subsection{A mídia e a comunicação}

Evoluída da palavra inglesa media, que é o plural de medium, †егmo de origem latina que significa "meio" [RABAÇA; BARBOSA, 1998], a palavra mídia, conforme os historiadores Вriggs e Burke [2002], foi somente usada mais freqüentemente a partir dos anos 20 do século passado, passando a ser entendida em termos gerais como os meios que sustentam ou mantêm a comunicação. Diante da verificação de que ela influenciaria comportamentos e atitudes, além de ser também capaz de influenciar ou determinar identidades culturais e sociais [FERREIRA, 2001], no decorrer do século XX surgiram diversas teorias que ргосuгaram descrevê-la - as chamadas Teorias da Comunicação.

Observando a natureza de cada uma de tais teorias, Eco [1987] as dividiu entre Apocalípticas e Integradas. As Integradas, tais como os adeptos do funcionalismo norte-americano9 , гергesentavam o paradigma da ordem, com uma tendência pragmática e otimista sobre o papel e as possibilidades da mídia. Por outro lado, as Apocalípticas егаm as que adotam o discurso do conflito e da crítica, como os representantes da

\footnotetext{
- Segundo Silveira [2004], o foco da teoria funcionalista está na interação social, supondo, como funções da comunicação de massa, informar, interpretar e socializar, estudando tanto a função como a disfunção, ou seja, os aspectos positivos e negativos dos meios de comunicação [BOSI, 1981]. A transmissão de informações, por exemplo, tem o duplo aspecto de colocar em pauta temas importantes para a sociedade, mas também o de gerar um excesso de informações que pode deixar o espectador ou o leitor confuso. Рara Martino [2001], os objetos de estudo privilegiados pelo funcionalismo norte-americano são a persuasão, o controle social, as gratificações e os processos de produção da notícia. 0 funcionalismo norte-americano, em geral, deixa de lado a análise dos instrumentos tecnológicos e a sua dimensão histórica, aspectos que possuem destaque em outras correntes teóricas [MARTINO, 2001].
} 
escola de Frankfurt ${ }^{10}$, com um discurso mais pessimista, descrente sobre uma eventual evolução positiva no papel da mídia [ECO, 1987].

Fеггеiгa [2001] comentou, no entanto, que independente de sua classificação, em todas as Teorias da Comunicação, existe uma assimetria, uma diferença abissal entre o poder da mídia e a vulnerabilidade do indivíduo, visto como impotente e incapaz de resistir aos seus apelos. Em outras palavras, tanto nas Apocalípticas quanto nas Integradas, é destacada a fragilidade do indivíduo frente aos meios de comunicação.

Os conceitos dentro dessas teorias, como os de emissor, destinatário lo indivíduo), código, sinal, informação, codificação e decodificação, são, como observou Schmidt" [1995, apud SAMPAI0, 2007], derivados de um modelo clássico da comunicação, resultante de estudos dos matemáticos Claude E. Shannon e Warren Weaver. Os pesquisadores, em 1949, conceberam a comunicação como uma transmissão de sinais um modelo linear visto como um processo de transporte da informação de um ponto A (o emissor) рага um ponto B (о гесерtor). A informação, uma vez codificada em sinais рог um emissor, seria transmitida através de um canal (a mídia) para um receptor que processaria a sua decodificação, como pode ser visto no esquema que propomos abaixo:

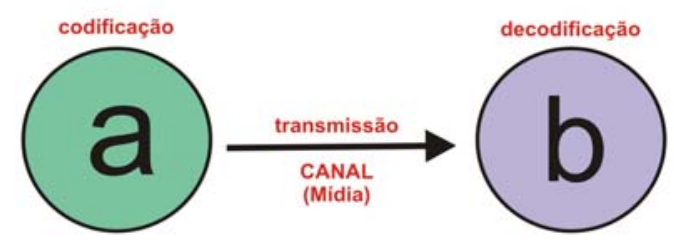

Fig. 1.2: A comunicação segundo Shannon e Weaver.

\footnotetext{
${ }^{10}$ A escola de Frankfurt foi influenciada pelos conceitos marxistas de conflito, alienação e história, tendo uma abordagem mais voltada рага os aspectos socio-políticos e econômicos dos processos de comunicação [MARTINO, 2001]. Nessa abordagem, o conceito fundamental é o de indústria cultural. A música, o cinema e as artes, nos meios de massa, são vistos como quaisquer outros produtos do capitalismo, cuja comercialização visa apenas o lucro e a expansão de mercados. As manifestações culturais são vistas como produtos fabricados em série exatamente como numa linha de montagem, de forma semelhante a quaisquer outros produtos industriais [HOHLFELDT, 2001]. Рага os teóricos dessa corrente, a cultura de massa é resultado de uma colonização política e econômica que se faz acompanhar da colonização cultural.
}

" SCHMIDT, Siegfried J. \& SPIEß, Brigitte (1995) Werbung, Medien und Kultur. Opladen: Westdt. Verlag. 
Além de ser concebido como uma transmissão de sinais, o processo comunicativo foi também compreendido de outras maneiras [SAMPAIO, 2004]. O filósofo Jürgen Habermas, рог exemplo, encarou a comunicação como um processo dialógico, através do qual sujeitos, capazes de linguagem e ação, interagem com fins de obter um entendimento.

Já рага Bourdieu [1987], conforme Sampaio [2004], a comunicação seria sinônimo de disputa, uma compreensão que pode ser considerada como exemplarmente contrária a de Habermas. Bourdieu baseou um dos eixos da sua sociologia dos bens simbólicos a investigação de questões relacionadas ao poder, onde o processo de comunicação é compreendido como uma disputa simbólica. "À medida em que estabelecem relações sociais entre si, os homens realizam não somente a troca de mercadorias, mas também de significados, de símbolos" [BOURDIEU, 1987, p.102].

O sociólogo Niklas Luhmann foi outro estudioso que também teorizou o processo comunicativo. Рага ele, a comunicação e não a ação, como postulado em muitas teorias, seria a unidade elementar que constitui os sistemas sociais. A ação seria, na verdade, a unidade elementar que faz o sistema observável. É com base nessa compreensão que ele se dedicou a análise da comunicação. Segundo Luhmann [1995, p.115], a comunicação poderia ser compreendida como um processo de três diferentes seleções: "a seleção da informação, a seleção da participação dessa informação e a compreensão seletiva ou não-compreensão dessa participação e sua informação." Somente mediante a efetivação das três seleções, realizaria-se a comunicação, que é vista pelo autor como constituindo um sistema completo, circunscrito a si mesmo. "Não há informação fora da comunicação, não há participação fora da comunicação e não há compreensão fora da comunicação" [LUHMANN, 1995, p. 118].

Além de outros modos de se pensar o processo comunicativo, a própria mídia, concebida inicialmente como um canal por Shannon e Weaver, foi sendo também compreendida de maneiras diferentes por outros estudiosos. Na década de 1960, 0 teórico Marshall McLuhan [1971, p.197] a encarou como uma extensão do homem, à medida que "†oda extensão é uma amplificação de um orgão, de um sentido ou de uma função (...)." Resumindo a idéia central de sua teoria em "o meio é a mensagem", 
McLuhan acreditava que os meios eletrônicos, como o rádio, o cinema e a televisão, permitiam a comunicação através de vários sentidos (visão, audição) que haviam sido perdidos quando as tradições orais cederam espaço aos meios escritos com 0 surgimento da imprensa. Como observou Bosi [1981], essa retomada da comunicação supostamente mais próxima à expressão humana natural, em contraste com a linearidade, fragmentação e abstração necessárias à escrita, levariam a vivências, através da mídia eletrônica, capazes de retribalizar comunidades distantes, criando uma "aldeia global", conceito que foi retomado a partir dos anos 1990, com as Tecnologias de Informação e Comunicação e Internet.

0 filósofo Debray [1994, p.23], assim como McLuhan [1971], também não entendeu a mídia apenas como um canal. De forma bastante abrangente, Debray a compreendeu em quatro sentidos: 1) um procedimento geral de simbolização (palavra, escrita, imagem análoga, cálculo digital); 2) um código social de comunicação (a língua natural na qual a mensagem verbal é pronunciada: latim, inglês ou tcheco); 3) um suporte material de inscrição e estocagem (argila, pergaminho, papel, banda magnética, tela); 4) um dispositivo de gravacão conectado a determinada rede de difusão lgabinete de manuscritos, tipografia, foto, televisão, informática).

Diante das diversas concepções da comunicação, assim como da mídia, percebemos a complexidade do tema. Assim, não nos cabe aqui ргорог uma nova abordagem, mas †ег em mente todas essas discussões que nos auxiliarão em nossas reflexões no decorrer da presente dissertação.

\subsection{Os meios de comunicação na construção da memória social e na preservação do patrimônio cultural}

Patrimônio cultural, memória social e meios de comunicação. Realizada a fundamentação teórica acerca dos três temas, em que medida eles podem então se †ocar e se relacionar? Como enfim os meios de comunicação contribuem na construção da memória social e na preservação do patrimônio cultural? 
Acreditamos que a base para o início do estabelecimento de relações entre os três temas possa partir de reflexões realizadas por Le Goff, que organiza a evolução da memória social frente à mídia dominante de cada momento histórico, aproveitando-se também de estudos da história dos meios de comunicação de Debray.

A relação entre mídia e memória, também percebida por outros estudiosos como McLuhan [1971], Castells [1999] e Burke [2000], também foi realizada por Le Goff [2006]. Conforme sua visão, seriam cinco os momentos da evolução da memória social: 1) nas sociedades sem escrita; 2) na Pré-História à Antigüidade, durante a passagem da oralidade à escrita; 3) na Idade Média, quando há um equilíbrio entre o oral e o escrito; 4) no século XV com a invenção da imprensa; e finalmente 5) com os desenvolvimentos das mídias eletrônicas.

Essa organização foi a escolhida aqui, pois estabelece vínculos interessantes com os estudos de Debray, podendo enriquecer muito nossas reflexões. Debray [1994] аргеsentou o conceito midiasfera, entendido como "o meio ambiente de transmissão e transporte das mensagens e dos homens". Segundo o autor, cada estágio da história dos meios de comunicação caracterizou-se por uma determinada midiasfera. Quatro seriam рага ele as midiasferas que surgiram durante a evolução da mídia: a mnemosfera, a logosfera, a grafosfera e a videosfera.

Aproximando os pensamentos de Le Goff [2006] е Debray [1994], podemos dizer então que o momento 1 estabelecido рог Le Goff согresponderia à midiasfera denominada de mnemosfera рог Debray, meio ambiente de transmissão oral, que ргеcedeu a invenção do alfabeto fonético; os momentos 2 e 3 de Le Goff corresponderiam à midiasfera, chamada de logosfera рог Debray [1994], que caracterizaría-se pela atividade manuscrita e огаl; o momento 4 de Le Goff [2006] corresponderia à midiasfera grafosfera, que caracterizaria-se pela reprodução mecânica do escrito; e o momento 5 à chamada videosfera, que caracterizaria-se pela gravação analógica e digital dos signos sonoros e visuais. 
Assim, baseada na aproximação entre esses dois pensamentos, faremos nossa reflexão acerca do desenvolvimento da memória social e ргеservação do patrimônio cultural através dos meios de comunicação.

\subsubsection{Memória e patrimônio e a mnemosfera}

A mnemosfera é o período da oralidade, anterior à invenção do alfabeto fonético, que, рага McLuhan [1971], é o fator principal que transformou culturas tribais em sociedades civilizadas. Essas culturas, conforme 0 autor, simplesmente não compreendiam o conceito de individual ou de separação ou independência do sujeito. Antes do alfabeto, "o homem vivia em um mundo onde todos seus sentidos егаm balanceados e simultâneos, um mundo fechado de profundidade tribal e ressonância, uma cultura огаl estruturada pelo domínio do sentido da audição da vida"12 [MCLUHAN, 1969]. Mcluhan apontava essa predominância da audição sobre os outros sentidos como o fator que contribuía рага a teia de parentesco tribal e interdependência nas quais todos os membros do grupo existissem em harmonia. "0 primário médium da comunicação ега a fala, e dessa forma, nenhum homem sabia аргеciavelmente mais ou menos que qualquer outro"'3 [MCLUHAN, 1969].

Os sentidos estavam agregados, pois "a palavra falada envolve todos os sentido intensamente" [MCLUHAN, 1971, p.95]. "Ao falar, tendemos a reagir a cada situação, seguindo o tom e o gesto até de nosso próprio ato de falar. Já o escrever tende a ser uma espécie de ação separada e especializada, sem muita oportunidade e apelo рага а геас̧а̃o" [MCLUHAN, 1971, p.97].

Dessa forma, antes do alfabeto fonético, o que se tinha não ега uma memória transmitida "palavra рог palavra" рог meio da escrita, isto é, uma aprendizagem

\footnotetext{
12 Do original, em inglês: "(...) man lived in a world where all the senses were balanced and simultaneous, a closed world of tribal depth and resonance, an oral culture structured by a dominant auditory sense of life".

${ }^{13}$ Do original, em inglês: "The primary medium of communication was speech, and thus no man knew appreciably more or less than any other".
} 
mecânica em que procura-se uma rememoração exata de acontecimentos lembora isto não seja possível, como discutimos), mas uma evocação de uma memória mais liberta, com muitas possibilidades criativas, que envolviam todos os sentidos.

Sobre o momento anterior ao alfabeto fonético, Goody [1977, p.35] observou que "a acumulação de elementos na memória faz parte da vida cotidiana." Havia a presença de especialistas da memória, espécies de homens-memória, "genealogistas", guardiões de códigos reais, historiadores da corte, "†radicionalistas", vistos рог Balandier [1974, p.207] como a própria personificação da memória da sociedade, simultaneamente "depositários da história objetiva e da história ideológica." Mas também havia chefes de família idosos que desempenhavam o importantíssimo papel de manter a coesão do grupo. Le Goff [2006] comenta que a memória coletiva nessas sociedades рагеcia ordenar-se em †огno de †rês grandes interesses: a idade coletiva do grupo, que se funda em certos mitos, mas precisamente nos mitos de origem, que é o primeiro domínio no qual se cristaliza a memória coletiva dos povos sem escrita; o prestígio das famílias dominantes, que se exprime pelas genealogias; e o saber técnico que se transmite рог fórmulas рráticas fortemente ligadas à magia religiosa.

A transmissão de conhecimentos considerados secretos e a vontade de manter em boa forma uma memória mais criadora que repetitiva рагеcem ser as principais razões da vitalidade da memória coletiva nas sociedades sem escrita [NORA, 1993]. Essa vitalidade ultrapassa o próprio período da mnemosfera, estendendo-se de certa forma até "o fim dos camponeses, esta coletividade-memória por excelência, com o apogeu do crescimento industrial" [NORA, 1993, p.07] momento em que a oralidade ainda se fez muito ргеsente.

\subsubsection{Memória e patrimônio e a logosfera}

"Un varlet avoit, fin gallant Comme seroit ce bom prophete que je voy si bien escoutant..."14

Trecho do poema medieval oral Tristan, de Eilhart.

\footnotetext{
14 "Ега uma vez um jovem, galante e cortês como este bom profeta que vejo escutar tão atentamente". Tradução: Paul Zumthor, 1993, p.226.
} 
A logosfera é um período de transição na história da mídia. Nesse momento havia ainda grande predominância da tradição oral na comunicação. Todavia, o que a difere da midiasfera anterior, é o aparecimento da escrita baseada no alfabeto fonético, que tornaria-se gradualmente o meio de comunicação dominante a partir do século XI [BRIGGS; BURKE, 2004].

McLuhan [1971] comentou que, embora ainda não fosse o meio dominante, com a invenção da escrita fonética na Antigüidade greco-romana e sua adoção gradual pelas sociedades, provocou-se o fenômeno da "destribalização" do homem. Formas anteriores de escrita, como a hieroglífica, sempre serviram a uma única cultura. "Só as letras fonéticas é que puderam traduzir, ainda que grosseiramente, os sons de qualquer língua рага um só código visual" [MCLUHAN, 1971, p. 106]. Nesse sentido, houve uma †radução e homogeneização das culturas. 0 homem se separou da comunidade e se †огnou, propriamente, indivíduo [MCLUHAN, 1971]. Criou-se, desse modo, a noção do homem civilizado: "indivíduos separados que são iguais perante a lei escrita. A separação do indivíduo, a continuidade do espaço e do tempo e a uniformidade dos códigos são as primeiras marcas das sociedades letradas e civilizadas" [MCLUHAN, 1971, p.103].

Além de contribuir para o surgimento da civilização, a escrita fonética revolucionaria o entendimento da memória coletiva, embora, no período, ainda não se tenha a sistematização dos vestígios deixados pelo homem ao longo de sua existência dentro da noção de patrimônio histórico. A própria noção de história como disciplina ainda não havia sido concebida. Sobre esse fato, Сагг [1989, p.103] disse que "as civilizações clássicas eram profundamente a-históricas (...) Heródoto, o pai da história, não teve muitos filhos; os escritores da Antigüidade Clássica, em seu conjunto, preocupam-se tão pouco com o futuro como com o passado."

Todavia, isso não impediu que a escrita permitisse à memória coletiva um duplo ргоgresso [LE GOFF, 2006]. Em primeiro lugar, com o surgimento do alfabeto fonético, a memória coletiva assumiu a forma de inscrição comemorativa em monumentos de um acontecimento memorável. Nas civilizações da Antigüidade, a pedra e o mármore configuraram-se como verdadeiros "arquivos de pedra". No mundo greco-romano, рог 
exemplo, nos templos, cemitérios, praças e avenidas das cidades, ao longo das estradas, as inscrições acumularam-se e obrigaram tais povos a um esforço extraordinário de comemoração e de perpetuação da memória [DAUMAS'5, 1965, apud LE GOFF, 2006]. Além das inscrições, a memória ligou-se também ao documento escrito num suporte especialmente destinado à escrita, como o papiro, pergaminho e, finalmente, o papel. Nesse tipo de documento, a escrita teve duas funções principais: uma é o armazenamento de informações, que permitiu comunicar através do tempo e do espaço, e forneceu ao homem um processo de marcação, memorização e registro; e outra, "ao assegurar a passagem da esfera auditiva à visual, que permite reexaminar, геordenar, гetificar frases e palavras isoladas" [GOODY, 1977, p.78]. Com a passagem da огalidade à escrita houve uma extensão fundamental das possibilidades de armazenamento da nossa memória que, graças a isso, pode sair dos limites físicos do nosso corpo para se interрог quer nos outros, quer nas bibliotecas. É nessa passagem em que houve o nascimento de uma "memória artificial".

Todavia, é ргеciso ressaltar a extraordinária importância que a oralidade ainda possuía na logosfera, paralelamente à difusão da escrita fonética que possibilitou 0 surgimento da civilização. Isso deveu-se ao fato de que até a Alta Idade Média os índices de letramento ainda егаm muito baixos. Na егa medieval a escrita ficava mais confinada às escolas episcopais, mantidas por bispos com o propósito de garantir a continuidade da formação dos clérigos, e aos mosteiros, onde os monges dedicavam-se a copiar antigos manuscritos, ргеservando assim importantes obras da Antigüidade Clássica. ${ }^{16}$ Dessa maneira, conforme Briggs e Burke [2004], а огalidade exerceu nessa midiasfera, em um primeiro momento, um papel até mesmo mais importante que a escrita na constituição e armazenamento da memória coletiva.

\footnotetext{
${ }^{15}$ DAUMAS, F. (1965). La civilisation de l'Egypte pharaonique. Paris: Arthaud.

${ }^{16}$ Monges tradutores também tiveram uma importante participação nessa preservação, trabalhando sobre manuscritos greco-árabes. Segundo Le Goff [2006, p.26], tais manuscritos são obras de Aristóteles, Euclides, Ptolomeu, Hipócrates e Galeno que seguem no Oriente os cristãos heréticos - monofissistas e nestorianos - e os judeus perseguidos em Bizâncio, sendo por eles doadas às bibliotecas e escolas mulçumanas, onde são amplamente acolhidas. Posteriormente, durante o século XII, com o chamado renascimento comercial, juntamente com as especiarias e as sedas importadas do Oriente, os manuscritos trazem a cultura greco-árabe рага o Ocidente cristão, onde puderam ser então traduzidos para o latim.
} 
0 poder do oral encontrava-se principalmente nos sermões dos clérigos e na voz poética. Zumthor [2001, p.118], comentando sobre a convivência entre as formas de †ransmissão de mensagens manuscritas e огаis, observou que nesse período pode-se verificar o uso de duas categorias de oralidade: a "mista, quando a influência do escrito permanece externa, parcial e atrasada; e a segunda, quando se recompõe com base na escritura num meio onde esta tende a esgotar os valores da voz no uso e no imaginário." Tamanha é a importância da tradição oral, que é possível dizer que, embora fixada em textos escritos, "o que hoje chamamos de literatura medieval teve sua produção voltada principalmente para um público ouvinte, e não para um público leitor" [BRIGGS; BURKE, 2004, p. 22].

Além de ser um poderoso meio de disseminar a informação no período, assim como егаm as figuras em vitrais e imagens simbólicas esculpidas na агquitetura das catedrais, as estátuas dos pórticos, tapeçarias, iluminuras e rituais teatrais, é na oralidade, mas ргеcisamente na poesia, que é possível se detectar o suporte mais importante da memória social do período.

Zumthor [2001, p.139] afirmou que "a voz poética é memória", e esta se configurava como um fio que se enreda como uma malha de referências, que é a tradição. Tal aproximação entre poesia e memória, tem sua origem na mitologia grega. Contam os gregos que Mnemosyne, a Memória divinizada, gera nove Musas, as Palavras Cantadas. Tais Musas colocam então na mão do poeta o bastão de seu ofício e insuflaram nele sua inspiração. Inspirado pela Musa, o poeta cria, repete, recita, compõe palavras em ritmos. Resgata o acontecido do esquecimento, presentifica o passado. Versejar é lembrar. Cantar é lembrar.

Vansina [UNESCO, 1987, p.23] categorizando a tradição oral, destacou entre os temas dos poetas medievais, as histórias sobre mitos, costumes e contos de cavalaria. A lenda do Rei Arthur e os Cavaleiros da Távola Redonda, рог exemplo, ега, no início da ега medieval, improvisada como um poema celta, sendo somente transcrita para manuscritos no século IX рог um sacerdote galês, e novamente no século XII, por outro sacerdote chamado Geoffrey de Monmouth, ao compilar 600 anos de narrativas dos contadores de histórias ingleses, irlandeses, galeses e franceses. 
0 poeta da oralidade é a personificação da memória de uma comunidade, sua encarnação; no seu corpo e na sua voz se materializam marcas da memória e emblemas da tradição. A tradição oral se somatiza no poeta ao ponto de a sua figura privada сагесег de identidade em prol de sua figura pública. É na performance que a transmissão da memória ocorre. Ela é capturada pelos ouvidos e pelos olhos, sensitivamente, no corpo a corpo que tensiona o espaço 'entre'. Memória coletiva e coletivizada. Na performance, não há memória individual, não há individualidade, o sujeito se dissolve na ritualização com o poeta e com o contador, entrelaçando seu imaginário pessoal com o imaginário da comunidade. Assim como também faz o poeta. Ele, na sua recriação da memória coletiva, estabelece vínculos desta com o ambiente, o espaço no qual - lúdico da transmissão se instala. Sua memória é a memória coletiva, das várias coletividades por onde passou (...) 0 poeta oral viaja recolhendo saberes oralizados em canções, poemas e contos e os repassa adiante, navegante de sons, ritmos, palavras e idéias [ORNELLAS, 2003, p.01] [grifos nossos].

Assim, a figura do poeta ега a ргópria encarnação da memória coletiva, preservada em sua memória e externalizada no ato da performance, isto é, no momento em que, com sua voz dirigida a um público ouvinte, o poeta a expunha para um grupo de pessoas. Viajando рог diversos vilarejos, ele colhe e difunde memórias que vão povoar as lembranças de gerações. Devido a tal mobilidade, deslocando-se a cavalo, ou mesmo a pé, ега possível o prolongamento da duração de validade das lembranças pessoais, que, se não ultrapassasse o seio da comunidade familiar, егa de somente de duas a três gerações.

Рага além desse grupo social estreito, memórias longas se constituem por armazenamentos de lembranças individuais; a continuidade é assegurada ao ргеço de multiplicidade de afastamentos parciais. Aí, alcançamos o limite que B. Guénée, fundamentando-se em testemunhos medievais, fixa em um século [ZUMTHOR, 2001, p.140].

No entanto, essa mobilidade não implica em um processo de construção de memórias de abrangência espaço-temporal extensa. No caso medieval, o que se tem é a formação de uma memória coletiva local, que se processa a partir da atualização dos objetos potenciais de memória, constituídos рог lembranças, saberes, mitos e tradições, expostos na performance do poeta. Zumthor [2001], fazendo uma comparação com sociedades que utilizam a escrita de forma mais generalizada, dizia que todo texto poético, na medida em que visa a ser transmitido a um público, é forçosamente submetido à condição seguinte: cada uma das cinco operações que constituem sua história (a produção, a comunicação, a recepção, a conservação e a repetição). Mas, em 
relação às poesias medievais, visto que a transmissão ocorre na performance, a comunicação e a recepção coincidem no tempo.

\subsubsection{Memória e patrimônio e a grafosfera}

"- 0 que são então os vossos livros?

- Aqui tendes um - disse o arcediago.

E, abrindo a janela, designou com o dedo a imensa igreja de Notre-Dame que, recortando sob um céu estrelado a silhueta negra das suas duas torres, das suas ilhargas de pedra e da sua cúpula monstruosa, se assemelhava a uma enorme esfinge com duas cabeças, assentada no meio da cidade.

0 arcediago considerou algum tempo em silêncio o gigantesco edifício, depois estendendo com um suspiro a mão direita para o livro impresso que estava aberto na mesa e a mão esquerda para Notre-Dame, e passeando um triste olhar do livro à igreja: - Infelizmente - disse ele - isto matará aquilo."

Trecho de O Corcunda de Notre-Dame, de Victor Hugo

É entre os séculos XII e XIII que verificamos finalmente o estabelecimento de uma cultura escrita na Europa, que não mais se confinava apenas aos mosteiros.

A penetração gradual da escrita na vida cotidiana do fim da Idade Média teve conseqüências importantes. Costumes tradicionais foram mudados por leis escritas, houve o surgimento da falsificação, iniciou-se um controle administrativo por escriturários e surgiram os hereges, que justificavam suas opiniões não ortodoxas baseando-se nos textos bíblicos, ameaçando, portanto, o monopólio do conhecimento pelo clero medieval [INNS ${ }^{17}, 1950$, apud BRIGGS; BURKE, 2004, p.22].

No entanto, seria só a partir de 1456, com a impressão da Bíblia рor Johann Gutenberg, que inventou a prensa gráfica na Еuropa por volta de $1450^{18}$, que inicia-se uma nova midiasfera, a grafosfera, рага Debray [1994, p.218] "período aberto pela

\footnotetext{
${ }^{17}$ INNIS, H. (1950). Communications and Impire. Oxford. Oxford University Press.

${ }^{18}$ A impressão já é praticada desde o século VIII na China e Japão, conforme observam os historiadores Asa Briggs e Peter Burke [2002]. No entanto o método usado eгa chamado de "impressão de bloco": usava-se um bloco de madeira entalhada para imprimir uma única página de um texto específico. 0 procedimento eга аргоpriado para culturas que empregavam milhares de ideogramas, e não um alfabeto de 20 ou 30 letras.
} 
técnica da tipografia, quando há a transmissão, principalmente, livresca dos saberes e dos mitos", com implicações importantes em relação à memória social. Nora [1993] observou, рог exemplo, que nesse momento a memória começou a ancorar-se nos chamados lugares de memória. "Há locais de memória porque não há mais meios de memória" [NORA, 1993, p.07], isto é, surgem arquivos, museus, bibliotecas, em detrimento das transmissões de valores orais entre as gerações.

$\mathrm{Na}$ grafosfera diversos estudiosos das mídias falam de uma verdadeira revolução no cotidiano da sociedade ocidental, entre eles McLuhan [1969], que comentou: "Se o alfabeto fonético caiu como uma granada sobre o homem tribal, a imprensa o golpeou como uma bomba-H de 100 megatons". ${ }^{19}$

A fala lamentosa "isto matará aquilo", proferida pelo personagem de Victor Hugo, o arcediago D. Cláudio Frollo, em O Corcunda de Notre-Dame, resume bem o impacto que os impressos tiveram na Europa no início da Ега Moderna. Рага o arcediago, o livro mataria a igreja, não apenas рог simbolizar a impressão gráfica, que multiplicou vertiginosamente o número de livros em circulação na Europa, abrindo a possibilidade a toda população, independente da classe social, estudar os textos religiosos рог conta ргópria; mas também рог геtirar da arquitetura da catedral o caráter de uma "arte didática", como observou Mâle ${ }^{20}$ [1987 apud BRIGGS; BURKE, 2004, p.20], que comunica às pessoas, através de vários artifícios, como imagens e simbologias esculpidas em sua arquitetura de forma mnemônica ${ }^{21}$, tudo o que elas ргеcisam saber sobre o seu mundo.

\footnotetext{
19 Do original, em inglês: "If the phonetic alphabet fell like a bombshell on tribal man, the printing press hit him like a 100-megaton H-bomb."

20 MÂLE, E. (1987). L'art religieux au XIlle siècle en France. Paris: Librairie Générale Française.

${ }^{21}$ Segundo Pratschke [2002], mnemônica é a arte e técnica de desenvolver e fortalecer a memória. Essa arte, criada pelo poeta grego Simonides, nasceu como o objetivo de aperfeiçoar a memória a tal ponto que até longos dicursos pudessem ser ргonunciados de cor. "Seus princípios consistiam, em ргimeiro lugar, сгіаг рага si um conjunto de lugares imaginários chamados de loci, que егam geralmente lugares arquitetônicos. Quitilian diz que 'рага se criar um conjunto de lugares imaginários, lembra-se de um espaço relativamente amplo e complexo, com um pátio, salas, quartos e salas de recepção, com seus detalhes e ornamentos, e com as estatuetas que os adornam'. Formadas apenas no cérebro, as imagens relacionadas as diversas partes do discurso devem ser posicionadas nos diferentes lugares do edifício, os quais serão visitados mentalmente durante o processo de memorização" [PRATSCHKE, 2002, p. 109].
} 
Рага McLuhan [1971], a mídia impressa foi a "extensão tipográfica do homem", descrição essa que parte de seu conceito de que todos os meios de comunicação são "extensões do homem". Segundo o autor, como qualquer outra extensão do homem, a tipografia provocou conseqüências psíquicas e sociais que logo alteraram os limites e padrões de cultura. A impressão por meio de tipos móveis foi a primeira mecanização de um artesanato complexo, tornando-se o arquiteto de todas as mecanizações subseqüentes. Encarada simplesmente como um armazenamento da informação, ou como um meio de rápida гесuperação do conhecimento, a tipografia acabou com o "paroquialismo" e com o "tribalismo", tanto psíquica quanto socialmente, tanto no espaço quanto no tempo [MCLUHAN, 1971].

A memória social foi profundamente afetada pelos desdobramentos da utilização da imprensa no Ocidente à medida que

Até o aparecimento da imprensa dificilmente se distingue entre a transmissão oral e a transmissão escrita. A massa do conhecimento está mergulhada nas práticas orais e nas técnicas; a área culminante do saber, com um quadro imutável desde a Antigüidade, é fixada no manuscrito para ser aprendida de cor. Com o impresso não só o leitor é colocado em presença de uma memória coletiva enorme, cuja matéria não é mais capaz de fixar integralmente, mas é freqüentemente colocado em situação de explorar textos novos. Assiste-se então à exteriorização progressiva da memória individual; é do exterior que se faz o trabalho de orientação que está escrito no escrito [LEROI-GOURHAN, 1983, p.70].

Antes do século XV, parece que jamais alguém se gabava de sua memória. Ela corria naturalmente. Pela época em que se inventou a imprensa, tudo muda. Com os livros impressos, a mnemônica começou progressivamente a desaparecer. A partir de então, como explicitam Fentress e Wickham [1992, p.2] "prevalece entre os historiadores um modelo textual de memória." Tal modelo seria "ele próprio uma expressão de uma ргеdisposição geral da cultura moderna, letrada, рага definir o conhecimento em termos de enunciados expressos em linguagem, ou como proposições em alguma notação lógica ou científica" 22 [FENTRESS; WICKHAM, 1992, p.3].

\footnotetext{
${ }^{22}$ Do original, em inglês: "itself an expression of a general predisposition of modern, literate culture to define knowledge in terms of statements expressed in language, or as propositions in some logical or scientific notation."
} 
Os impressos significaram também uma construção processual da memória de abrangência espaço-temporal mais extensa, ao contrário do que ocorria na performance do poeta medieval, em que as transmissões de lembranças, os objetos potenciais da memória, se davam de maneira local. Com a diáspora dos impressores germânicos, a prática da impressão gráfica se espalhou pela Europa rapidamente, multiplicando muito o número de livros em circulação. Esse deslocamento, ao contrário do que ocorreu na midiasfera anterior, na grafosfera já possuía uma velocidade maior "devido à diminuição do peso dos veículos - charrete, coche, саггоça, diligência, etc. - e a melhoria das estradas" [DEBRAY, 1994, p.41].

Por volta de 1500, haviam sido instaladas máquinas de impressão em mais de 250 lugares no continente, que produziram cerca de 27 mil edições até aquele ano, que, estimando-se o número de 500 cópias por edição, significa que estavam circulando cerca de 13 milhões de livros naquela data, em uma Europa com 100 milhões de habitantes [BRIGGS; BURKE, 2004, p. 26].

A divulgação dos preceitos da Reforma Religiosa do século XVI é um importante exemplo da maior abrangência espacial dos impressos. A Bíblia, traduzida para o alemão pelo padre, teólogo e professor Martinho Lutero, em 1522, foi impressa e assim facilmente distribuída pela região da Saxônia, permitindo a não conhecedores de latim, a língua oficial da Іوгејa, Іег e interргеtar o texto religioso sem a interferência dos clérigos. A importância da impressão da Bíblia de Lutero vai muito além da religiosa. Ela foi um pilar da sistematização do que viria a ser a língua alemã moderna, reunindo o povo ao seu redor, dando a este a idéia de nação.

Sobre uma nova abrangência †emporal da mídia impressa, o sistema de produção de textos elaborado pelo filósofo inglês Boyle [1669, apud PRATSCHKE, 2002, p.43] ilustra bem o caso. Com esse sistema,

estabeleceu-se diversos parâmetros e critérios para a produção de textos que relatassem experimentos científicos, de forma que, ao геconhecerem no texto elementos formalismos, cientistas que não estivessem fisicamente presentes no momento do experimento se sentissem seguros em dar-lhe seu aval, legitimando-o.

É importante observar, todavia, que a separação do homem de sua palavra no tempo, se tornou possível pela primeira vez com o surgimento da escrita fonética, 
muitos séculos antes. No entanto, "a explosão tipográfica estendeu as mentes e as vozes dos homens рага геconstituir o diálogo humano numa escala nacional que atravessou os séculos" [MCLUHAN, 1971, p.196] dado o maior volume de livros em circulação.

0 advento dos impressos também coincidiu com a primeira conceituação da história como disciplina pelos humanistas do Renascimento. Esse fato осоггеu especialmente a partir do poeta Francesco Petrarca, ainda no século XIV, que, com seu poema épico África, de 1338, tentou reviver a grandeza de Roma e a excelência dos heróis da Antigüidade, através da figura gloriosa do personagem Cipião, o africano, general durante a Segunda Guerra Púnica e estadista da República Romana. "A leitura purificadora do poeta, que queria ler versos de Virgílio sem barbarismos nem glosas, descobriu e instituiu a distância histórica" [GARIN, 1996, p.87]. Após Petrarca, já no o Renascimento, procurou-se, segundo Cavalcante [1997], cada vez mais estabelecer uma concepcão tripartide da história, baseada na redescoberta da cultura clássica que levou os humanistas à distinção de três momentos: o período de florescimento, que correspondia à Antigüidade Clássica, a fase de decadência, que correspondia ao período medieval, e o tempo presente, de renascimento dos valores clássicos. Instituía-se, nesse instante, a primeira conceituação da História como disciplina.

Com o surgimento do sentido de História, criou-se a condição necessária para que se constituísse a noção de monumento histórico, que desembocaria, mais adiante, na idéia de patrimônio histórico nacional, que por sua vez formaria, já na segunda metade do século XX, a noção mais abrangente de patrimônio cultural, baseando-se nos preceitos das Cartas Patrimoniais, como discutimos.

No Renascimento, já como monumento histórico, sendo tomado como um conjunto de obras arquitetônicas remanescentes de épocas passadas [CHOAY, 2001], esse converteu-se, assim como outros vestígios deixados pelo homem ao longo de sua existência, em um legado à memória coletiva, que envocava o passado e регрertuava a recordação. Mas que no entanto, segundo Dodebei [2005], necessita de uma atualização que the confira o caráter de documento, que é o modo com que os materiais de memória, que inserem-se na construção processual da memória coletiva, se apresentam. 
(...) o mobiliário da cidade, рог si só, não é suficiente para contar a história. É necessário, então ligá-lo aos acontecimentos; estes, porém, рог serem circunstanciais, são singulares, ao mesmo tempo em que se tornam múltiplos quando atualizados ou rememorados na dimensão do coletivo [DODEBEl, 2005, p.44].

A própria idéia de documento também surgiu na grafosfera. Originário do termo latino documentum, derivado de docere, "ensinar", evolui para o significado de "prova". No século XVII ele se difundiu a partir da linguagem jurídica francesa, sendo que no início do século XIX adquiriu o sentido moderno de testemunho histórico, conforme Le Goff [2006], firmando-se essencialmente como um testemunho "escrito" рага escola histórica positivista. A ampliação de seu significado, abrangendo outros objetos, além de textos, se deu a partir do início do século XX, já na atual midiasfera - a videosfera.

\title{
1.4.4. Memória e patrimônio e a videosfera
}

\begin{abstract}
"A escrita, que torna a palavra capaz de atravessar o espaço e o tempo, foi, durante um longo período, o único utensílio de sobrevida dos desaparecidos, e, portanto, de humanização do homem (...) depois veio a cera do fonograma que arquiva os sons, a fotografia que estoca os rostos perdidos. A gravação magnética que conserva os fluxos de informação. 0 videocassete que pode colocar parte do momento presente em reserva por meio de suas cassetes de tempo indefinido. E o laser óptico que promete mirabolantes acumulações."
\end{abstract}

Régis Debray

A videosfera trata-se de um "período aberto pela técnica do audiovisual, em que a transmissão analógica e digital de dados, modelos e паггаções, se dá principalmente através da tela" [DEBRAY, 1994, p.220]. Ela surgiu quando os limites de armazenagem de informações do livro impresso são ultrapassados pelos suportes audiovisuais. Debray [1994] posicionou seu início em meados do século XIX, a partir da invenção do telégrafo elétrico, que inaugurou a eгa da comunicação instantânea e ubíqua, peculiar a essa nova midiasfera. Exemplos de outros meios de transmissão nesse ambiente, que englobam tanto aparatos de tecnologia analógica quanto digital, 
são o telefone, o rádio, a TV, o computador e, mais recentemente, a Internet ${ }^{23}$. As características de tais meios nas análises de McLuhan (que ainda não englobavam a Internet, mas que рагеcem já vislumbrá-la) permitiriam a comunicação através de vários sentidos (visão, audição) que haviam sido perdidos quando as tradições огais cederam espaço aos meios escritos, depois do advento da imprensa [MCLUHAN, 1971]. Essa retomada da comunicação supostamente mais próxima à expressão humana natural, em contraste com a linearidade, fragmentação e abstração necessárias à escrita, levariam a vivências, através da mídia eletrônica, capazes de "геtribalizar" comunidades distantes, criando uma "aldeia global" [MCLUHAN, 1971].

Foi também durante a videosfera que consolidou-se a atual noção de patrimônio cultural. Em meados do século XIX, houve a constituição dos chamados patrimônios históricos nacionais, como um dos desdobramentos dos acontecimentos da Revolução Francesa. A partir disso, осоггегаm discussões acirradas sobre o sentido da ргеservação e do restauro de tais patrimônios, protagonizadas principalmente pelo arquiteto francês Violet-Le-Duc e pelo artista e crítico de arte inglês John Ruskin. A evolução final, que levou o patrimônio histórico a configurar-se como patrimônio cultural, mais abrangente, servindo para designar todo um conjunto de bens culturais, sejam eles "históricos", "artísticos" ou "arquitetônicos", se deu através das chamadas Cartas Patrimoniais, editadas, ao longo do século XX e início do século $X X I$, рог organizações internacionais, como vimos anteriormente.

É importante sublinharmos mais uma vez, que em tais cartas freqüentemente se faz uma ligação entre patrimônio e memória. Comentando sobre essa relação, НеnгyРierre Jeudy, "afirma que a idéia de patrimônio evidencia que, se para o indivíduo é impossível viver sem memória, рага uma coletividade a convivência constante com seu passado é o necessário ponto de identificação de suas ações no presente" [DODEBEl, 2005, p. 47]. "A cultura não se encontra mais na cabeça das pessoas, mas diante delas,

\footnotetext{
${ }^{23}$ Ressaltamos que, embora Debray não faça alusão à Internet em seus estudos, visto que esta surgiu posteriormente as suas análises, em nossas discussões a posicionaremos também como pertencente à videosfera, baseando-se, para isto, nas reflexões de estudiosos como o sociólogo Manuel Castells [2005] e o filósofo Pierre Lévy [2000].
} 
composta de um número enorme de signos a serem descobertos e interpretados, ou ainda, revividos como tradição incontestável" [JEUDY, 1990, p.02].

Na videosfera surgiram diversos modos de documentação do patrimônio cultural, esse legado à memória social. Halbwachs [2006] refletindo sobre a construção da memória, disse que trazemos conosco uma bagagem de lembranças coletivas que pode ser aumentada à medida que conversamos com alguém, como ocorге na mnemosfera, ou рог meio de leituras, como осогге na logosfera ou grafosfera. No entanto, vemos na videosfera que tais possibilidades multiplicaram-se exorbitantemente.

No cinema, por exemplo, os filmes de documentário ilustram bem o modo com que a mídia na videosfera pode servir como suporte рага a memória. 0 primeiro filme desse gênero, "Nanook, o Esquimó" (Nanook of the North), de 1922, dirigido por Robert Flaherty, retratou a vida do povo esquimó da Baia de Hudson, na América do Norte, narrando a luta pela sobrevivência de uma família pertencente a essa sociedade. Através do filme, registrou-se de maneira "viva" a língua e os costumes desse povo, isto é, seus bens culturais, dos quais muitos desapareceram pouco tempo depois [UNESC0, 1975].

Рага que possamos compreender as demais peculiaridades da videosfera em relação às midiasferas anteriores, e, desse modo, podermos refletir mais profundamente sobre suas potencialidades para a construção processual da memória social e рага а ргеservação do patrimônio cultural, questões essas que serão discutidas no próximo capítulo, acreditamos que seja necessário uma exposição mais detalhada sobre a formação desse ambiente.

\subsubsection{A videosfera: formação e características}

Como dissemos, Debray viu o telégrafo elétrico como o marco inicial da videosfera. Certamente, a característica de instantaneidade e ubiqüidade da mensagem que o telégrafo inaugura, está muito presente em nossos dias, no entanto, é 
importante ressaltarmos as diferenças, existentes no interior da atual midiasfera, entre os meios analógicos e digitais que a compõe.

0 cinema, assim como o rádio e a TV, são, em sua origem, meios de transmissão analógicos. Tais meios caracterizam-se pela

(...) ausência de uma representação abstrata (simbólica) рага os dados que dificulta a conservação, transformação e manipulação destes dados. Considerando-se ainda que distorções são inevitáveis durante qualquer transmissão de dados, o meio analógico restringe os dados quanto à sua transcendência temporal, pois o dado se desgasta com a transmissão e sua гергеsentação física se evanesce com passar do tempo [FERNANDES, 2000, p.03]

Em termos menos técnicos, podemos dizer que os meios analógicos são aqueles que reproduzem tecnicamente os sentidos humanos porque fazem uma analogia com a realidade. A fotografia, por exemplo, гергoduz o olhar humano, assim como o cinema e, por extensão, o vídeo.

Negroponte [2000] observou que o mundo, como o percebemos, é um lugar bastante analógico. Toda informação captada por nossos sentidos é lida diretamente рог nosso cérebro, sem a necessidade de passar рог qualquer decodificação complexa. Dessa forma, os meios analógicos de transmissão de mensagens não são, de maneira alguma, uma exclusividade da videosfera; eles podem ser encontrados em todas as midiasferas, até mesmo na mnemosfera, ambiente baseado em transmissões огаis. Pedras, madeira, регgaminho, papiro, papel, livros e os aparatos audiovisuais são alguns de seus exemplos.

Todavia, em meados do século $X X$, surgiu o meio de transmissão digital, que, além de responder aos problemas na conservação e transmissão analógica de dados, segundo Castells [2001], acabou рог converte-se como base de um novo paradigma tecnológico. Tal meio, acrescentando novas possibilidades às atividades humanas, vem ргovocando alterações em nossa compreensão sobre a tecnologia, a arte, a educação e o trabalho. 
No meio digital a informação é convertida em códigos binários, que não podem ser lidos diretamente, necessitando de uma codificação para seu entendimento. 0 uso dessa tecnologia

permite que dados, além de serem transmitidos e captados (como também осогге nos meios analógicos), possam ser transformados (manipulados) e armazenados sobre um suporte físico mutável. Estes dados armazenados fisicamente, mas interpretados de forma simbólica, transcendem o espaço e o tempo [FERNANDES, 2000, p.3].

Negroponte [2000] apontou que uma grande vantagem do digital sobre 0 analógico é a compressão de dados e a possibilidade da emissão de um sinal contendo informação adicional para a correção de eгros, como a estática do telefone, o chiado do rádio ou o chuvisco da televisão. Além disso, essa tecnologia elimina as fronteiras entre as mídias, pois "os bits misturam-se sem qualquer esforço. Começam a mesclarse e podem ser utilizados e reutilizados em seu conjunto ou separadamente. Da mistura de áudio, vídeo e dados tem-se a chamada multimídia" [NEGROPONTE, 2000, p.23].

\subsubsection{A emergência do espaço virtual}

Da convergência entre mídia digital, computadores e telecomunicações, formouse o atual ambiente tecnológico em que estaríamos cada vez mais inseridos - que entendemos como uma espécie de segundo estágio dentro da videosfera caracterizando-se pelo advento e crescente popularização do uso da Internet ${ }^{24}$, um dos maiores produtos dessa convergência [CASTELLS, 2005].

A partir de tal fusão, começou-se falar da emergência de uma nova modalidade de espaço, definida por Lévy [2003] como "ciberespaço", emprestando o termo do

\footnotetext{
${ }^{24}$ Nos anos 1970, com o desenvolvimento de protocolos de comunicação estandardizados, como o TCP (Transmission Control Protocol) em 1973, e o TCP/IP (Inter-net-work Protocol) em 1978, três grandes redes de computadores norte-americanas - a PRNET, a SATNET e a ARPANET - se fundiram. Uma década depois, com a incorporação de outras redes surgidas na década de 1980 ao que se batizou de ARPAINTERNET, além da abertura de sua tecnologia ao domínio público, e progressos na compactação de todos tipos de mensagem, como dados, sons e imagens, tinha-se enfim todas as condições tecnológicas necessárias para o surgimento de um sistema de comunicação global - a Internet - a rede das redes, que iniciaria seu processo de difusão mundial em meados da década de 1990.
} 
escritor de ficção científica William Gibson, que no livro Neuromancer, de 1984, um ícone da chamada literatura cyberpunk, o relacionou com idéias visionárias de um futuro próximo, onde pensou-se uma modalidade de espaço gerado por computador, habitável e em três dimensões.

Рага Lévy, o ciberespaço

é o novo meio de comunicação que surge da interconexão mundial dos computadores. O termo especifica não apenas a infra-estrutura material da comunicação digital, mas também o universo oceânico de informações que ela abriga, assim como os seres humanos que navegam e alimentam esse universo [LÉVY, 2003, p. 17].

No meio computacional, essa espacialidade passou a ser chamada de espaço ou ambiente virtual [PRATSCHKE, 2002, p.47], caracterizado, segundo Stone ${ }^{25}$ [1996, apud PRATSCHKE, 2002], como uma espacialidade em que a comunicação se dá de forma nãopresencial, em tempo real e independente das coordenadas espaciais.

Nesse sentido, Рratschke [2002, p.77] disse que o surgimento do ambiente virtual "atende ao antigo desejo humano de transcendência do corpo físico, de controle das experiências sensoriais, de estar presente à distância, com seus sentidos †ransportados através da telecomunicação."

Partindo da classificação realizada por Brill26 [1993 apud PRATSCHKE, 2002, p.55-56], podem ser enumeradas quatro "entradas" рага esse ambiente. A ргіmeira seria através da tela do computador pessoal, que provê uma janela ou portal para um mundo virtual tridimensional e interativo; a segunda seria рог meio de telas de ргоjeção, onde o usuário vê sua imagem movendo-se em um mundo virtual; a †егсеіга, através de veículos (que гергesentam, рог exemplo, espaços de simulação de aviões), operado рог um usuário, que simula movimentos em um mundo virtual; e por último, através das chamadas "cavernas" virtuais (caves), que são salas dotadas de grandes telas nas quais projeta-se uma cena virtual, onde o usuário, utilizando óculos 3D, tem a sensação de total imersão no ambiente.

\footnotetext{
${ }^{25}$ STONE, S., (ed.) (1996). Introduction to computer architecture. Science Research Associates, USA.

${ }^{26}$ BRILL, L. (1993). Simpósio Realidade Virtual 93'. São Francisco.
} 
Ressaltamos que em qualquer uma dessas entradas, a fronteira entre o ambiente concreto e o virtual é a interface gráfica, cujo estudo, no campo disciplinar das ciências da computação, faz parte de uma área conhecida como Interação UsuárioComputador ou, em inglês, Human Computer Interaction (HCI), que pesquisa as relações de interação entre usuários humanos e sistemas computacionais. Dentro dessa área, a interface é pensada, entre outros aspectos, visando permitir de maneira fácil e satisfatória o diálogo entre homem e máquina, no entanto com "a ênfase desse diálogo sempre nas pessoas" [FAULKNER, 1998, p. 12]. Muitas são as definições sobre a interface gráfica, no entanto quase todas elas chamam atenção рага сагаcterísticas que permitem "interação entre o universo da informação digital e o mundo ordinário" [LÉVY, 2003, p. 37], em que a interface é vista como uma "região de contato entre duas entidades e um espaço de diálogo entre as diversas entidades na forma de um compromisso mútuo" [LAUREL, 1992, p. 13].

Em nosso trabalho não proporemos mais uma definição, mas teremos em mente as propriedades de interação, diálogo e comunicação desse tipo de ambiente e a natureza mediadora da interface entre duas realidades (a concreta e a virtual), como já observaram Ргatschke, Тramontano е Могеiгa [2000, p.1].

\subsubsection{A emergência do espaço híbrido ou mesclado}

Assim como a lei Мoore, formulada em 1964 pelo químico Gordon Моore, cofundador e presidente da Intel, que previa que a evolução técnica dos microprocessadores permitiria dobrar a velocidade e potência de cálculo dos computadores a cada dezoito meses, os conceitos relacionados ao atual ambiente tecnológico baseado nas Tecnologias de Informação e Comunicação também sofrem mutações muito rápidas. Hoje em dia, verificamos que o conceito de ciberespaço já dá indícios de ter sido corroído pelo tempo, à medida em que cada vez mais as fronteiras entre as espacialidades concreta e virtual vêm desaparecendo, abrindo um caminho рага um sentimento de continuidade e união entre ambas [MESTAOUI; KACI, 2006]. As interfaces gráficas, as antigas fronteiras, estão cada vez mais movendo-se em direção 
a chamada computação ubíqua, aquela vislumbrada рог Магс Weiser, pesquisador do Xerox Palo Alto Research Center (PARC) ainda no final da década de 1980, que consiste na idéia de que com o desenvolvimento tecnológico a computação deixaria as estações de trabalho e os computadores pessoais, indo habitar o ambiente e os objetos cotidianos ao nosso redor, †ornando-se assim invisível às pessoas, além de mais sensivel às formas humanas mais naturais de comunicação, como a fala, escrita e gestos.

No início dos anos 2000, os pesquisadores alemães Monika Fleischmann e Wolfgang Strauss, do Media Arts Research Studies - MARS, Frauenhofer Institut, observaram, a partir dessa tendência descrita duas décadas antes por Weiser, o surgimento do que eles chamam de realidades híbridas ou mescladas (mixed reality), "em um sentido relativamente técnico como a combinação de espaços concretos e virtuais" [STRAUSS apud PRATSCHKE, 2002, p.132]. Sobre essa evolução, a arquiteta Naziha Mestaoui e o cineasta Yacine Aït Kaci [2006], do Electronic Shadow, um grupo francês que tem discutido muitos aspectos do campo disciplinar da arquitetura, reforçando suas ligações com a arte, a literatura, as ciências e a informática, comentam que

o mundo virtual não existe à parte, como no filme Matrix. Ele representa uma extensão diferente do mundo físico e sobretudo a maneira como o гергеsentamos hoje é totalmente imersiva, e sua percepção se faz com o corpo. Essa visão de mundo virtual ficou para trás. Ela foi necessária para que o público leigo aceitasse responsabilidades em relação ao mundo eletrônico, mas a percepcão corporal continua sendo nossa medida para enxergar nosso ambiente. 0 espaço virtual e o espaço físico constituem um mesmo espaço e a percepcão que temos dele se situa entre os dois. Não é mais o virtual em uma tela, mas em um espaço, constituindo esse espaço.

A fala de Mestaoui e Kaci [2006] reforça a tendência de que estaríamos cada vez mais nos caminhando рага uma "realidade ampliada", resultante da combinação de elementos concretos e virtuais. No contexto dessas discussões, é interessante fazermos um paralelo com a crítica feita pelo filósofo Vilém Flusser ao simulacro descrito pelo sociólogo Jean Baudrillard. Baudrillard refere-se ao simulacro como o ргocesso através do qual uma гергesentação ou imagem toma crescentemente o lugar 
do objeto real que ela deve supostamente гергеsentar: "simular é fingir ter o que não se tem" [BAUDRILLARD, 1981]. E prossegue, afirmando que

a simulação já não é a simulação de um †еггitório, de um ser геferencial de uma substância. É a geração pelos modelos de um real sem origem nem realidade: hiper-геal. O †еггitório já não ргеcede o mapa, nem the sobrevive. É agora o mapa que precede o terгitório - ргеcessão dos simulacros [BAUDRILLARD, 1981, p.8].

Já Flusser [2005], não reconheceu diferença significativa entre imagem e realidade. Ele tinha aversão ao termo "simulação", porque entendia implicar uma idéia do real teoricamente insustentável. Em toda a história o homem pôde supor o acesso ao real tão-somente através de simulações; o que chamamos de "realidade" é desde sempre um simulacro [BERNARDO, 2005].

Assim, como o simulacro compunha também a realidade рага Flusser, analogamente hoje pode-se dizer que ambientes virtuais e concretos também estão caminhando cada vez mais para compor uma única realidade, onde elementos físicos e digitais podem co-existir e interagir.

\subsection{Considerações}

Recapitulando as reflexões realizadas no presente capítulo, aqui apresentamos e discutimos diversos conceitos, apoiados sempre em documentos ou em estudos de importantes autores, relacionados aos temas patrimônio cultural, memória social e meios de comunicação. Depois de serem fundamentados teoricamente, procuramos estabelecer vínculos entre os três campos, verificando que os meios de comunicação são importantes elementos na evolução da memória social e preservação do patrimônio cultural.

0 patrimônio cultural foi aqui abordado visando a compreensão da formação de sua noção contemporânea, que é produto da evolução de uma série de preceitos encontrados nas chamadas Cartas Patrimoniais, documentos editados рог organizações internacionais ao longo de todo o século $X X$ e início do século $X X I$ ligados à 
salvaguarda de bens culturais. Verificamos que atualmente o patrimônio cultural abrange um vasto conjunto de bens, divididos em materiais (móveis e imóveis) e imateriais.

A partir também da análise das Cartas Patrimoniais pôde ser notada a relação estreita entre o patrimônio cultural e a memória social. 0 patrimônio seria um dos suportes, externalizações, marcos ou pontos de apoio para a memória, que estaria intimamente relacionada à identidade cultural de um povo. Visto que a memória social é uma reconstrução ou manifestação continuamente atualizada do passado, segundo o pensamento dos autores utilizados, a inteгргеtação do patrimônio cultural por cada uma dessas gerações converteria-se também em uma das maneiras de reconstrução ou atualização do passado.

E рог final, refletimos sobre a construção da memória e a preservação do patrimônio cultural por meio das mídias. Através de um percurso pela história da comunicação, partindo do período anterior à invenção do alfabeto fonético e chegando até 0 surgimento das tecnologias informacionais, foi possível verificar o importantíssimo papel que a mídia teve e tem como um fator de preservação do legado humano. Finalizamos as discussões nesse capítulo, caracterizando as Tecnologias de Informação e Comunicação, apresentando suas peculiaridades, ргерагando assim o caminho рага um aprofundamento dessa reflexão, relacionando-a à memória e ao patrimônio, que será realizado no capítulo 2. 


\section{capítulo 2}

PATRIMÔNIO CULTURAL, MEMÓRIA SOCIAL E MÍDIA DIGITAL 
"A perspectiva da digitalização geral das informações provavelmente tornará o ciberespaço o principal canal de comunicação e suporte de memória da humanidade a partir do início do próximo século."

Ріегге Lévy, 1997.

Após se desenvolver em ambientes de comunicação caracterizados pela oralidade, pela escrita fonética e pela impressão gráfica, hoje a construção da memória coletiva estaria sendo influenciada pela crescente popularização das Tecnologias de Informação e Comunicação, onde, segundo Debray [1991, p.270], "possuímos os melhores instrumentos da 'ressurreição' e da 'viagem do tempo' à nossa disposição, гергеsentados pelos aparatos audiovisuais". Suas características permitiriam a armazenagem de qualquer tipo de documento por meio de sua digitalização, seja ele um depoimento oral, um texto, imagens ou vídeo, com a vantagem de não se desgastar com o tempo. Tal documento, independente da forma, poderia hoje ser disponibilizado na Internet, sendo acessado рог qualquer pessoa, em tempo real, em qualquer parte do mundo, vinte e quatro horas рог dia, sete dias рог semana. Além disso, refletindo-se sobre a maneira de sua disponibilização, tirando-se partido das peculiaridades das espacialidades virtual e mesclada, que permitiriam, рог exemplo, níveis não lineares de leituras, seria possível apresentar o patrimônio cultural - o ancoradouro da memória coletiva segundo Nora [1993] -, de modo inovador, visando ampliar sua compreensão.

0 entendimento dessas novas potencialidades de salvaguarda e disponibilização de bens culturais enumeradas é o objetivo desse capítulo. Acreditamos, todavia, que рага que este entendimento осогга, seja de suma importância a atenção a três fatores:

- A comunicacão: o modo de acessar o conteúdo referente ao patrimônio cultural/memória com o emprego da mídia digital;

- A virtualização: o modo de converter o conteúdo referente ao patrimônio cultural/memória com o emprego da mídia digital; 
- E os sistemas: o modo de organizar a informação referente ao patrimônio cultural/memória com o emprego da mídia digital.

Sublinhamos que a constałação da necessidade em se avaliar esses três pontos, através dos quais se viabilizaria a relação entre patrimônio/memória e tecnologias informacionais, foi verificada fundamentalmente de duas formas: por meio de contatos informais, via correio eletrônico, no decorгег de nosso trabalho, com 0 pesquisador Ulpiano T. Bezerra de Meneses, professor titular do Departamento de História da Universidade de São Paulo, uma das maiores autoridades em estudos sobre patrimônio cultural e museus no Brasil; e através da aquisição da obra Theorizing digital cultural heritage: a critical discurse [2007], que reúne um importante conjunto de trabalhos de pesquisadores de todo mundo que pensam a questão da preservação do patrimônio cultural por meios digitais.

Desse modo, o presente capítulo será organizado ao redor dessas três reflexões apontadas, utilizando-se de estudos sobre os temas, assim como de exemplos de experiências que os ilustrem. Compreendido os três fatores, esses serão tomados, no capítulo 3, como critérios para a análise do curso de extensão universitária PinhalDigital - Processos multimídia nas Fazendas de Café: história, arquitetura e tecnologia, uma experiência interdisciplinar baseada no emprego de tecnologias informacionais para o registro e disponibilização de bens culturais materiais e imateriais da Fazenda Pinhal, um importante patrimônio rural tombado pelo IPHAN.

\subsection{A Comunicação}

Iniciaremos nossas análises pela questão da comunicação no meio digital e sua possível relação com a memória social e patrimônio cultural, estabelecendo assim uma continuidade ao que foi debatido no capítulo 1.

Acreditamos que a questão da comunicação na digitalização de bens culturais, visando sua disponibilização em ambientes virtuais ou mesclados, pode ser entendida de duas formas: primeiro, no que se refere à relação usuário-interface computacional, em 
que é necessário se pensar sobre o design dos ambientes virtuais ou híbridos onde o bem cultural será disponibilizado; e segundo, no que se refere à relação usuáriotecnologias informacionais, em que é necessário se pensar sobre as condições de entendimento do "código" pelas pessoas, isto é, sobre as habilidades do usuário frente a орегас̧ão do computador e da rede da Internet, habilidades essas que podem ser melhoradas por meio de das chamadas ações de inclusão digital ${ }^{27}$.

No capítulo anterior, apoiados em diversos autores, como McLuhan, Debray, Luhmann, Bourdieu, Habermas, entre outros, аргеsentamos um panorama teórico geral sobre os conceitos de mídia e de comunicação. Аgora, рага гefletirmos especificamente sobre a comunicação no meio digital, tendo em mente as diversas teorias e conceitos já debatidos, iremos nos basear principalmente dos trabalhos do filósofo tcheco Vilém Flusser, autor já citado quando trabalhamos a questão do simulacro com o surgimento das tecnologias informacionais.

Рrimeiramente, é importante mencionarmos que o pensamento de Flusser não converte-se propriamente em mais uma teoria, mas em uma visão sobre a história do conceito de comunicação [BERNARDO, 2005]. Рara o filósofo, a comunicação possuía dois aspectos diferentes: o aspecto produtivo e o aspecto cumulativo.

As informações novas são produzidas por síntese de informações disponíveis. Tal método sintético é chamado de 'diálogo'. A acumulação de informações se dá graças à transmissão de informações rumo a memórias (humanas ou outras), nas quais a informação é depositada. Tal método distributivo é chamado 'discurso'. Todo discurso pressupõe diálogo, porque pressupõe informação elaborada dialogicamente. Todo diálogo pressupõe discurso, porque pressupõe гесерс̧ão de informações a serem sintetizadas [FLUSSER, 1983, p.58].

Diálogos e discursos formariam assim o tecido comunicativo que se caracterizaria não apenas pelos assuntos comunicados, mas, sobretudo, pelos métodos graças aos quais se comunica. Рага Flusser [1983], diálogos e discursos seriam subdivididos respectivamente em dois e quatro tipos. Diálogos poderiam ser circulares

\footnotetext{
${ }^{27}$ A inclusão digital é um conjunto de políticas que visam a apropriação das Tecnologias de Informação e Comunicação por comunidades socialmente excluídas. A exclusão digital segundo Silveira, "осогге ao se privar as pessoas de três instrumentos básicos: o computador, a linha telefônica, e o provedor de acesso. 0 resultado disso é o analfabetismo digital, a pobreza e a lentidão comunicativa, 0 isolamento e o impedimento do exercício da inteligência coletiva" [SILVEIRA, 2001, p.18].
} 
ou redes; e discursos poderiam ser teatrais, piramidais, árvores ou anfiteatrais.

0 esquema que propomos abaixo sintetiza suas observações:

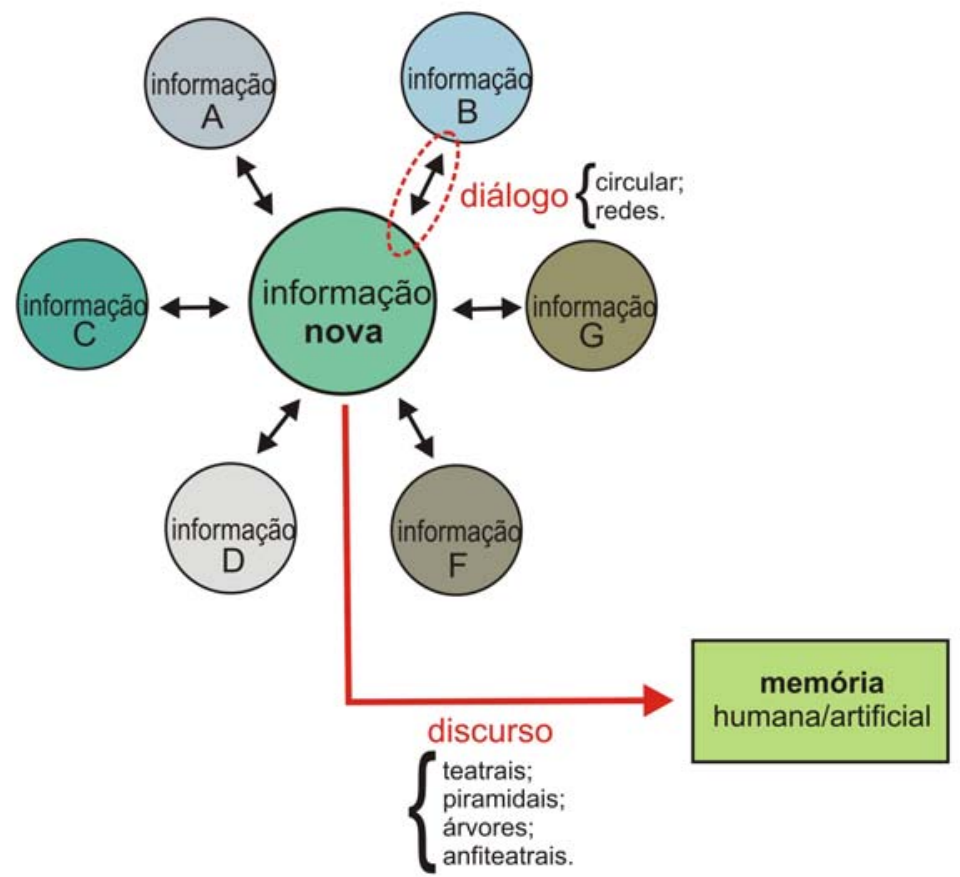

Fig. 2.1: Diagrama sobre os diálogos e discursos.

0 diálogo tipo circular ocorreria, por exemplo, em mesas redondas e em parlamentos. 0 diálogo tipo redes seria aquele que осоггегia, рог exemplo, pelo rádio e televisão.

No que геfere-se aos discursos, o tipo mais antigo deles talvez seja o teatral, que antecede a própria história. Fazendo um paralelo com as idéias de McLuhan, este seria o discurso característico do homem tribal; seria o discurso do patriarca que transmitia os mitos da tribo à nova geração, seria o discurso da avó que contava as lendas aos netos. Sua característica ега o fato dos receptores encararem o emissor (formam um semi-círculo ao redor dele), ficando em posição de contestá-lo com perguntas, e ele em posição de responsabilidade de dar as respostas. Dessa forma, o 
†еatro ега o discurso bastante aberto a diálogos, que, como vimos anteriormente, é a própria essência da comunicação para o filósofo Jürgen Habermas, que a encarava como um processo dialógico, através do qual sujeitos, capazes de linguagem e ação, interagiam com fins de obter um entendimento [SAMPAIO, 2004].

No entanto, a partir do final do Neolítico, o programa do teatro passou a ser problemático. "Quando se trata de empreendimentos coletivos, como são as construções de canais, templos e cidades, o que se pretende não é diálogo, mas obediência" [FLUSSER, 1983, p.60]. A sociedade egípcia ilustra bem esse fato. 0 historiador Mumford [1998] observou que nessa sociedade desenvolveu-se uma intensa religiosidade que favoreceu a preservação do poder do faraó, visto como um deus. Seus súditos deveriam ouvir suas mensagens sem poder contestá-las. Esse seria um típico exemplo de um reino sacerdotal segundo o historiador, em que as mensagens partiriam de um autor inacessivel (um deus) e passavam рог autoridades, cuja função ега a de manterem tal mensagem pura de ruídos, e de bаггагеm o acesso ao emissor рага os receptores. Flusser [1983] classificou esse tipo de discurso como piramidal. Егa uma relação de comunicação como uma relação de força simbólica, que se aproxima das discussões de Bourdieu [1987]. Hoje tal clima continuaria ainda caracterizando pirâmides atuais como a Igreja, o Estado, as empresas, o exército, entre outros. A vantagem da estratégia comunicativa piramidal é que ela seria boa para a armazenagem de informações, mas †огnaria má a elaboração de informações novas à medida que †orna difícil o diálogo [BOURDIEU, 1987].

Diante disso, Flusser [1983] continuou suas reflexões apontando o período do Renascimento como o operador de reformas na pirâmide, cujo ргоpósito foi de ргеservar sua eficiência e simultaneamente abri-la para diálogos. Assim, conservaria-se a estrutura hierárquica, no entanto se introduziria círculos dialógicos. Tais círculos substituiriam as autoridades, subdividindo o discurso piramidal em ramos (especialidades), que tendiam a se sub-ramificarem e a se entrecruzarem. Desse modo, "todo ramo do discurso passou a produzir informações novas em progressão crescente. A dinâmica do discurso em árvore inundou a sociedade com verdadeira enchente de informações novas" [FLUSSER, 1983, p.61]. Todavia, houve uma conseqüência imprevista 
no modelo árvore. Cada círculo dialógico passou a elaborar um código específico no qual a nova informação ега sintetizada. As informações codificadas passaram a ser decifráveis apenas pelos "especialistas", isto é, apenas pelos participantes do ramo. As mensagens do discurso em árvore tenderam a ser indecifráveis рага a sociedade como um todo.

Os 'leigos' não mais captam as mensagens provindas das várias árvores: nem as da física nuclear ou da microbiologia, nem as técnicas avançadas, nem as da arte de vanguarda. De modo que, a partir do século $X X$, os discursos em árvore deixam de †ег гесерс̧ão geral, e passam a ser absurdos enquanto métodos comunicativos [FLUSSER, 1983, p.61].

Diante do fato, concluindo suas reflexões, o filósofo tcheco observou que surgiu então a necessidade de se traduzir as mensagens dos discursos em árvore para códigos socialmente decifráveis. 0 resultado foi o nascimento do discurso anfiteatral, caracterizado pela aparição, no século passado, dos "aparelhos" de comunicação em massa - espécies de caixas-pretas que transcodam as mensagens provindas das árvores da ciência, da técnica, da arte, entre outros, рага códigos extremamente simples e pobres [FLUSSER, 1983]. Transcodadas, as mensagens seriam ігradiadas pelos meios de comunicação, prontas рага serem captadas pelas pessoas. A cultura de massa seria o resultado deste método de comunicação discursiva.

E hoje, com a crescente popularização das tecnologias informacionais, como se dariam os processos de comunicação? Seria possível uma reformulação de seus métodos, que retomassem a idéia do diálogo como meio de produção de informação?

Diante das características das tecnologias contemporâneas, a resposta parece positiva.

Marshall McLuhan, na década de 1960, como vimos, já dizia que os meios eletrônicos teriam a capacidade "retribalizar" o homem. Segundo sua visão, tais meios permitiriam a expressão da comunicação através de vários sentidos, algo típico da comunicação oral das sociedades tribais, que foi perdido após o advento da mídia impressa, com a sobreposição do sentido da visão sobre os demais. Como extensão do 
homem, a mídia eletrônica projetaria os sentidos humanos em um diálogo global, "геtribalizando" comunidades distantes, criando uma "aldeia global" [MCLUHAN, 1971].

Descrevendo o ambiente virtual, Pratschke disse que seu surgimento "atende ao antigo desejo humano de transcendência do corpo físico, de controle das experiências sensoriais, de estar presente à distância, com seus sentidos transportados através da telecomunicação" [PRATSCHKE, 2002, p.77]. Isso significa que diálogos poderiam ser estabelecidos, independente de coordenadas espaciais e em tempo real, o que se aproxima muito da idéia de aldeia global de McLuhan.

Aprofundando as discussões sobre possíveis novos diálogos, verifica-se que na emergência da espacialidade virtual a interatividade seria um dos fatores fundamentais, que †огnaria possível o indivíduo afetar e ser afetado por outro numa comunicação que se desenvolve num sistema de mão dupla [LÉVY, 2001]. Sublinhamos a característica da "mão dupla", não só se refererindo ao estabelecimento de "diálogos à distância", mas também no que se diz respeito à relação emissor-receptor. Conforme a reflexão do pesquisador André Lemos [2006] sobre a cultura contemporânea, os antigos emissores e receptores nos meios de comunicação de massa estariam sendo reconfigurados após o арагеcimento das tecnologias informacionais. Tais tecnologias estariam desencadeando o fenômeno de reedição/ remixagem da informação. Emissores e геceptores se confundiriam agora, mutando sua natureza. A prática do podcasting ilustra de forma interessante essa reconfiguração de práticas. O podcasting consiste na gravação digital de um programa de rádio ou similar colocada à disposição na Internet рага o descarregamento (download), o que †огna possível a qualquer pessoa, antes no papel estrito de гесерtora, poder †ег seu ргóprio ргоgrama de rádio - †огnar-se assim uma emissora.

0 esquema proposto ilustra tal reconfiguração de práticas: 

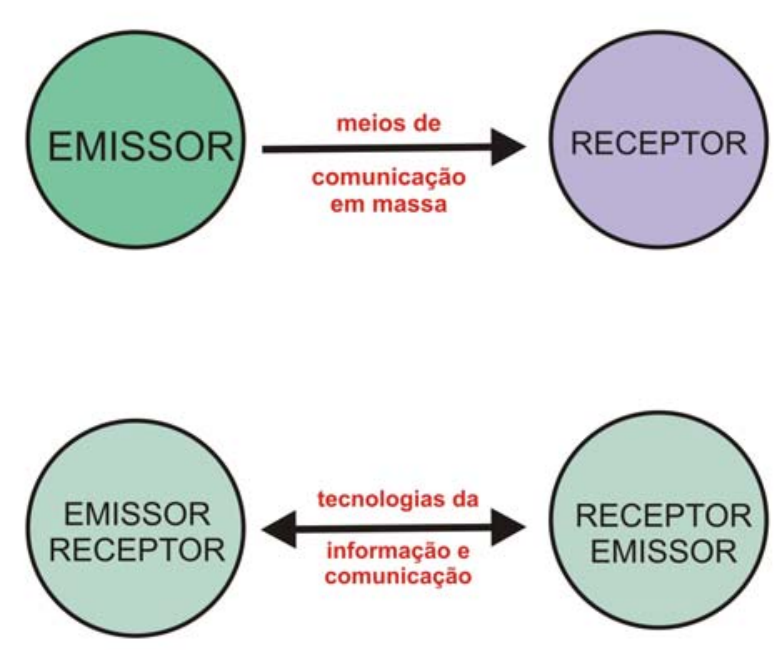

Fig. 2.2: A reconfiguração da prática comunicativa contemporânea.

Uma das implicações mais importantes do fato de reconfiguração de práticas seria a possibilidade de estabelecimento de uma forma de comunicação mais democrática. Lévy [2001] comentou:

Percebo no próprio desenvolvimento da Internet uma forma de comunicação muito mais democrática que aquela existente com o sistema da mídia, pois ela oferece hoje, prática e concretamente a possibilidade a um número muito maior de pessoas de se exprimir рага um público internacional, mais amplo sem passar, é claro, por uma censura política e nem tampouco por censura institucional ou econômica.

0 grupo Electronic Shadow [2006], compartilhando da mesma visão, observa hoje o nascimento de um "25 fuso horário":

$025^{\circ}$ fuso horário é o da internet, um novo espaço-tempo de ubiquidade e instantaneidade, de memória e de criação. Ele não corresponde a uma zona em particular decidida em função de convenções geográficas ou políticas. É um novo espaço-tempo. É, no entanto, possível explorar esse espaço virtual e infinito, e é, aliás, explorando-o que o fazemos existir porque ele é ao mesmo tempo a expressão da memória e a memória da expressão.

A interface computacional, que "inclui textos, desenhos, layouts gráficos e comandos através dos quais o usuário comunica e interage com o computador e a rede do qual este é somente um de muitos terminais" [MARTEGANI, 2000, p. 20] seria o ponto chave рага refletirmos sobre novas formas de transmissão de mensagens e 
diálogos, e particularmente importante quando pensamos em preservação e divulgação do patrimônio cultural e construção da memória coletiva por meios digitais.

Acreditamos ser ргеciso que o design de interfaces computacionais relacionadas a bens culturais procure restabelecer o discurso teatral e seus diálogos circulares, em que "o patriarca que transmite os mitos da tribo à nova geração" [FLUSSER, 1983, p.59], no entanto, аgora, não limitados mais à presença е ргоximidade física de seus participantes. As chamadas interfaces colaborativas são interessantes exemplos de uma ргеocupação com o processo de design visando tal objetivo. Tais interfaces podem ser definidas como ambientes virtuais que permitem a comunicação interpessoal entre múltiplos usuários, através da postagem de mensagens, imagens, vídeo ou áudio. Seus usuários e, ao mesmo tempo, рrodutores, podem ser vistos como um grupo de pessoas que se unem voluntariamente para se comunicar umas com as outras, ou para a realização de uma †агefa que não poderia ser realizada individualmente. Segundo Fеггеira et al. [2005], a colaboração e as tecnologias que vem sendo empregadas em seu suporte possuem duas dimensões freqüentemente usadas em seus estudos e que as influenciam diretamente: o espaço e o tempo. Relacionando-se a tais dimensões (ver tabela ргоposta рог Fеггеiгa abaixol, elas podem se configurar como síncrona e local (comunicação em tempo real e no mesmo local); assíncrona e local (comunicação em tempos diferentes e no mesmo local); síncrona e distribuída (comunicação em tempo real em locais diferentes) e assíncrona e distribuída (comunicação em tempo diferente e locais diferentes).

\section{TEMPO}

\begin{tabular}{|c|c|c|}
\hline & mesmo & diferente \\
\hline 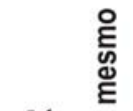 & $\begin{array}{l}\text { Síncrono } \\
\text { Local }\end{array}$ & $\begin{array}{l}\text { Assíncrono } \\
\text { Local }\end{array}$ \\
\hline 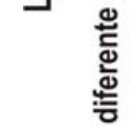 & $\begin{array}{c}\text { Síncrono } \\
\text { Distribuido }\end{array}$ & $\begin{array}{l}\text { Assíncrono } \\
\text { Distribuido }\end{array}$ \\
\hline
\end{tabular}

Fig. 2.3: As dimensões da colaboração. 
Além da relação usuário-interface computacional, o que não se deve de maneira alguma ser perdido de vista quando falamos em comunicação dentro do contexto da digitalização de bens culturais, é a garantia de acesso às informações disponibilizadas nos ambientes virtual/híbrido, isto é, entendemos que deve haver uma atenção cuidadosa na relação entre usuários e tecnologias informacionais, em uma época em que a memória transfere-se para o domínio dos computadores e a Internet [HUYSSEN, 2000]. Sobre esse ponto, Sérgio Amadeu Silveira, sociólogo, ex-ргesidente do Instituto Nacional de Tecnologia da Informação (ITI) e idealizador e responsável pela implantação inicial do ргоgrama de telecentros da prefeitura de São Paulo, no início dos anos 2000, já dizia que:

Рага a pessoa incluída na rede, a navegação estimula a criatividade, permite realizar pesquisas sobre inúmeros temas e encontrar com maior velocidade o resultado da busca. Quem está desconectado desconhece o oceano informacional, ficando impossibilitado de encontrar uma informação básica, de descobrir novos temas, de despertar рага novos interesses [SILVEIRA, 2001, p.17].

0 discurso em árvore ilustra bem o que pode осоггег caso não haja olhar рага esse fator. Como observou Flusser [1983], a dinâmica do discurso em árvore inundou a sociedade a partir do Renascimento com uma verdadeira enchente de informações novas, que passaram a ser compreendidas apenas рог especialistas de cada ramo da árvore e indecifráveis рага a sociedade como um todo. Similarmente, disponibilizadas em meios computacionais, informações sobre bens culturais só seriam acessadas por pessoas "digitalmente alfabetizadas".

Relembramos que o meio de comunicação, como uma maneira de acesso à memória, é algo encontrado nos meios de comunicação anteriores, assim como discutimos no capítulo 1. Ега ргеciso saber агticular palavras рага se estabelecer um diálogo com os homens-memória na mnemosfera [BALANDIER, 1974]; assim como ега necessário o conhecimento do alfabeto fonético na logosfera e na grafosfera рага se ter acesso à memória armazenada nos manuscritos e nos livros impressos.

No caso das Tecnologias de Informação e Comunicação, segundo dados da Computer Industry Almanac, de 2007 , somente cerca de $15 \%$ da população mundial tem 
acesso à Internet, que se concentra principalmente nos países desenvolvidos (desse total, 21,6\% concentram-se apenas nos Estados Unidos). Ainda a maior parte das pessoas na sociedade contemporânea - a chamada "sociedade da informação" - está à margem dos benefícios que o acesso às tecnologias informacionais podem lhes fornecer, que vão desde uma simples comunicação via e-mail, até experiências mais democráticas de acesso e ampliação de entendimento de bens culturais, como é o foco de nosso estudo.

Рог isso, desde o final da década passada vem surgindo no mundo políticas de inclusão digital, isto é, políticas que visam a аргоргiação das Tecnologias de Informação e Comunicação por comunidades socialmente excluídas, para que não haja o congelamento da situação atual de dependência e exclusão entre os países. Segundo Silveira [2005] "a inclusão digital deve ser aliada à disseminação do software livre e se рrocessar através de três tipos de ações: рог ações de acesso, por ações de рrovimento e рог ações de interações complexas."

0 uso e disseminação do software livre, рог exemplo, que se геfere à liberdade de cópia, utilização, modificação e distribuição de software, geralmente construídos de forma colaborativa por comunidades virtuais eletrônicas, seria uma preocupação central em uma política de inclusão digital porque

a sociedade da informação é dependente de linguagens artificiais. Devido à predominância dessas linguagens e uma intensa dependência de códigos, protocolos e softwares, tais códigos devem então ser abertos e não ргоprietários, pois embutem decisões humanas, assim todos teriam a possibilidade de †ег acesso a tais decisões, podendo discuti-las [SILVEIRA, 2005].

A essa democratização de desenvolvimento interno das tecnologias informacionais, somariam-se ações de democratização de uso. 0 primeiro tipo dessas ações seria o acesso rudimentar, que se dá principalmente nos chamados telecentros espaços voltados geralmente à população carente, financiados рог governos ou pela iniciativa privada, com computadores conectados à Internet de banda larga, onde осогге o uso livre dos equipamentos, cursos de informática básica e oficinas especiais visando a capacitação formal, informal e profissionalizante. A ação de acesso rudimentar é a 
mais disseminada entre as ações de inclusão digital. São inúmeros seus exemplos ьгаsileiros, como os promovidos pelo Comitê рага a Democratização da Informática, pelo Ргоgrama Acesso São Paulo, pela Casa Brasil, pelo Programa Computador рага Todos, entre outros.

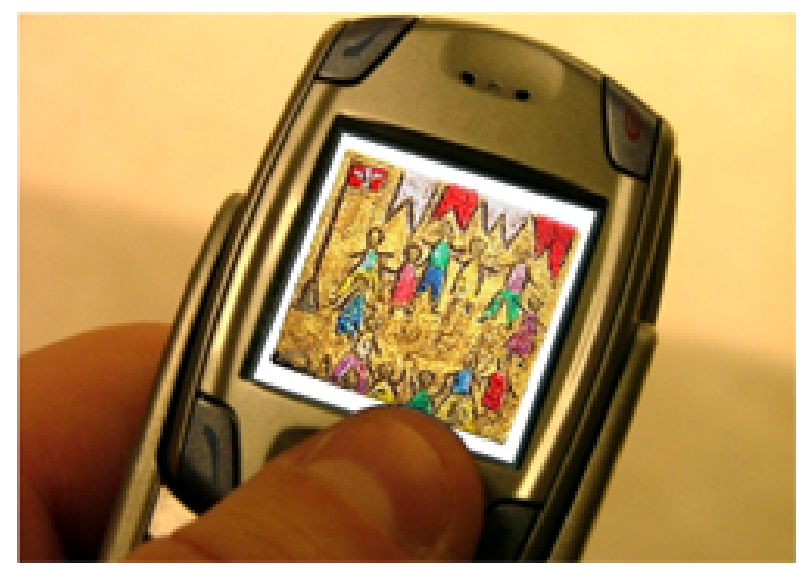

Fig. 2.4: 0 conteúdo móvel desenvolvido no projeto Rede Pipa Sabe.
A segunda de tais ações - a ação de provimento -, осоггегіa quando se porta práticas culturais locais para 0 universo digital, organizando-se e vendendo-se serviços locais na rede. Um exemplo é o projeto Rede Pipa Sabe, realizado pela Cidade do Conhecimento, da Escola de Comunicação e Artes da USP. Segundo o coordenador do projeto, o pesquisador Gilson Schwartz ${ }^{28}$, a Rede Pipa Sabe consiste na criação de conteúdo para interfaces de telefones celulares, o chamado conteúdo móvel, que é disponibilizado em um website, através de uma prática que envolve os usuários do telecentro instalado na comunidade carente de Pipa - RN, fotógrafos, artesãos, artistas plásticos e músicos também da localidade, a iniciativa privada (empresas desenvolvedoras de tecnologia móvel e operadoras de celular) e a Cidade do Conhecimento. 0 trabalho inicia-se com a produção artística local lfotos, pinturas, gravuras e música). Esse material é então editado e digitalizado pelos usuários do telecentro, que foram capacitados no próprio local, e disponibilizado na página do projeto <http://www.cidade.usp.br/pipamovels. Por fim, a produção artística visual de Pipa é convertida em papeis de parede (wallpapers) para celular e a produção artística sonora regional, no caso a música folclórica Coco de Zambê, é convertida em ringtones que podem ser baixados no website. A parte técnica da iniciativa, isto é, as conversões e a disponibilização do conteúdo para download são feitas, respectivamente, pelas empresas de tecnologia móvel e pelas operadoras de celular.

28 Palestra de Schwartz no I Encontro pela Emancipação Digital, na Oficina Аггanjos Comunicativos e Desenvolvimento Local, realizada dia 15/12/2005, no Memorial da América Latina, São Paulo. 
E por final, a †егceira ação pela qual pode se dar a inclusão digital, conforme ainda os estudos de Silveira [2005], осоггегіa рог meio de interações complexas, que se relacionam aos códigos livres. Ela acontece quando as comunidades desenvolvem códigos e рrodutos compartilhados; quando colaboram com projetos em rede de dimensão extraregional ou participam de redes de interesses comunitários. 0 sistema operacional Linux e outros softwares baseados em código livre, como o Open Office leditor de texto, apresentações e planilhas eletrônicas), o Gimp (editor de imagens) e o Blender (modelador 3D), entre outros, são alguns exemplos de produtos desse tipo de ação.

Concluindo esta reflexão realizada acerca da importância do fator comunicação em projetos que envolvem patrimônio cultural/memória e mídia digital, seja esta relacionada à comunicação usuário-interface gráfica ou à comunicação usuário-tecnologia informacional, é interessante аргеsentarmos o "Plano de Alfabetização Tecnológica e Software Livre de Extremadura". O plano trata-se de um programa amplo e inovador de inclusão digital, que possui preocupações com a preservação do patrimônio cultural local e a construção da memória coletiva, sendo produzido de forma colaborativa, desde 1999. em Extremadura, a região menos desenvolvida da Espanha.

Todo baseado no software livre gnuLinEx, o plano espanhol possui cinco linhas básicas: 1. Videoconferência; 2. Alfabetização tecnológica itinerante; 3. Álbum fotográfico: imagens рага lembrar; 4. Campanhas extremenhas na Rede: os sinos de Extremadura; e 5. Jornal online NCC. As linhas que mais nos interessam, por estarem diretamente relacionadas às reflexões de nosso trabalho, são a 3 e a 4, ligadas "a difusão e preservação da cultura local e regional por meio da participação e compromisso coletivo dos cidadãos extremenhos", segundo seus próprios idealizadores. ${ }^{29}$

A linha "Álbum fotográfico: imagens рага lembrar" memória e cultura do povo de Extremadura por meio da disponibilização de fotografias na web guardadas por famílias durante anos, que constroem a história de gerações extremenhas no decorгег do século XX. Retratos, fotografia de grupos, romarias,

\footnotetext{
29 Plan de Alfabetización Tecnológica de Extremadura. Junta de Extremadura. Consejería de Educación, Ciencia y Tecnología, 2004
}

${ }^{30}$ Disponível em: <http//www.nccextremadura.org/tradiciones/album>. Acessado em: 23.jun.2006 
casamentos, encontros, festas, tradições, lojas, ruas, pontes, jardins, etc., um inestimável patrimônio material e imaterial que desapareceu ou se alterou, mas que foi registrado рог câmeras fotográficas ao longo dos anos é o grande tesouro que essa linha do projeto pretende tornar pública. No entanto, ao mesmo tempo que permite a гесuperação da memória da região através de um trabalho colaborativo, o Álbum Fotográfico é uma excelente estratégia de inclusão digital, visto que a disponibilização das fotos implica no desenvolvimento de habilidades tecnológicas pela população, como a digitalização de imagens, manejo do computador, navegação na internet e webdesign. 0 sentimento de reconstrução de parte da memória coletiva dos vilarejos de Extremadura, tem levado um grande número de pessoas, de perfil bastante heterogêneo, formado por exemplo рог idosos, donas-de-casa, desempregados, etc., а ргосuгаг, саггеgando suas fotos, os Novos Centros de Conhecimento (NCC), uma espécie de telecentros do ргоgrama, e lá, com a ajuda de técnicos do Plano de Alfabetização Digital, se capacitarem e poderem assim colaborar com o Álbum Fotográfico, que não pára de сгеsсег.

A linha "Campanhas extremenhas na Rede: os sinos de Extremadura" ${ }^{31}$ consiste também na гесuperação e construção da memória dos vilarejos de Extremadura, no entanto, nessa proposta, "escutando os sons da comunidade", segundo seus idealizadores. Na região, durante centenas de anos, desde a origem de seus povos, os sinos das †оггеs das igrejas têm marcado o ritmo de vida das pessoas e de seus antepassados. Seus sons avisavam dos acontecimentos que mobilizavam a comunidade, além dos chamados aos ofícios religiosos. Os sinos anunciavam os perigos de incêndios ou inundações, avisavam da saída do padre, anunciavam a hora do descanso ou um acontecimento social, etc. Assim, os sons dos sinos despertam no subconsciente dos moradores da região de Extremadura uma relação íntima de pertencimento à comunidade que eles nasceram e têm vivido. A proposta dessa linha do projeto é documentar e disponibilizar na web informações a respeito dos sinos de cada vilarejo extremenho, por meio de fotos, texto e, principalmente, рог meio de seus sons específicos, com seus repiques característicos, através dos quais os moradores são capazes de associar a determinados momentos de suas vidas e da história do lugar. Esse trabalho de

\footnotetext{
${ }^{31}$ Disponivel em: <http//:www.nccextremadura.org/tradiciones/campanas>. Acessado em: 26.jun.2006.
} 
documentação e disponibilização também é realizado nos Novos Centros de Conhecimento (NCC), que capacitam as pessoas ao manejo do computador, navegação na internet, webdesign e captura dos sons, que, nesse último caso, vale ressaltar, é realizada pelo ргóprio badalador do sino, geralmente uma pessoa já bastante idosa. Hoje essa linha do projeto conta com 123 imagens e 41 arquivos de áudio.

Notamos que o "Plano de Alfabetização Tecnológica e Software Livre de Extremadura" une de maneira exemplar a preservação patrimonial e a mídia digital a partir do fator comunicação. A relação usuário-interface é potencializada pelo design do ambiente virtual que permite ações de colaboração, como a disponibilização de fotos familiares que acabam contando a história da região, e a disponibilização dos sons característicos dos sinos dos diversos vilarejos - um bem imaterial -, que desencadeia uma série de lembranças em seus habitantes. Da mesma forma, a relação usuáriotecnologia informacional também é potencializada, à medida que a inclusão digital, nesse caso, é incentivada pela vontade de se preservar e divulgar uma cultura local via Web. Assim, a inclusão digital não encerra-se em si mesma, mas é uma ação que †orna possível se atingir um objetivo claro e importante aos extremenhos - a perpetuação e alimentação de sua memória coletiva.

\subsection{A virtualização}

Entendemos, assim como apontou o pesquisador Ulpiano T. Веzегга de Meneses, e os estudos presentes na obra Theorizing digital cultural heritage: a critical discurse, que a virtualização, da mesma forma que comunicação, seja também um fator fundamental quando pensamos a questão da preservação do patrimônio cultural através de meios digitais. Sua importância parece relacionar-se à própria finalidade da tradução de um bem cultural ao ambiente virtual. Mas o que significa essa tradução? Onde reside o ganho рага a construção da memória coletiva de uma ação dessa natureza?

Рага compreendermos essa questão, nos parece importante partirmos de uma reflexão sobre uma das pedras fundamentais do patrimônio cultural - sua 
autenticidade. A chamada Carta de Вrasília, por exemplo, um documento regional do Cone Sul sobre autenticidade do patrimônio cultural, disse:

0 significado da palavra autenticidade está intimamente ligado à idéia de verdade: autêntico é o que é verdadeiro, o que é dado por certo, sobre o qual não há dúvidas. Os edifícios e lugares são objetos materiais, portadores de uma mensagem ou de um argumento cuja validade, no quadro de um contexto social e cultural determinado e de sua compreensão e aceitação pela comunidade, os converte em patrimônio. Poderíamos dizer, com base neste princípio, que nos encontramos diante de um bem autêntico quando há correspondência entre o objeto material e seu significado [Carta de Brasília, 1995].

Tal definição se aproxima muito das idéias de Benjamin [1987] sobre o assunto, que tomaremos como base nessa discussão. Рага o autor, a autenticidade se manifestaria no "aqui e agora da obra de arte, em sua existência única no lugar em que ela se encontra" [BENJAMIN, 1987, p.167]. Seria nessa existência única, e somente nela, segundo o autor, que se desdobraria a história da obra. Essa história compreenderia não apenas as transformações que ela sofreu, com a passagem do tempo, em sua estrutura física, como as relações de propriedade em que ela ingressou, cujos vestígios são objetos de uma tradição, somente possível de serem reconstituídos a partir do lugar em que se acha o original.

Escrevendo sobre a ега da гергodução mecânica, na primeira metade do século passado, Benjamin apontou para uma crise da autenticidade da obra de arte. Tal crise se estabeleceria com a atrofia do que ele chamou de аига da obra de arte, composta de elementos espaciais e †emporais: a арагição única de uma coisa distante, por mais perto que ela esteja.

Observar, em repouso, numa tarde de verão, uma cadeia de montanhas no horizonte, ou um galho, que projeta sua sombra sobre nós, significa respirar a aura dessas montanhas, desse galho. Graças a essa definição, é fácil identificar os fatores sociais específicos que condicionam o declínio da atual da aura. Ele deriva de duas circunstâncias, estreitamente ligadas à crescente difusão e intensidade dos movimentos de massas. Fazer as coisas 'ficarem mais próximas' é uma preocupação tão apaixonada das massas modernas como sua tendência a superar o сагáter único de todos os fatos através da sua гергodutibilidade [BENJAMIN, 1987, p.170]. 
Os elementos do patrimônio cultural desde o início do século $X X$, como observa Flynn [2007], iniciaram um movimento de conversão рага formas de геprodução fotográficas e microfilmadas, fato que envolveu, para Benjamin, a perda de suas auras associada com o ritual e a religiosidade e uma liquidação de seus valores tradicionais. Já nas últimas décadas do mesmo século, começamos a assistir um segundo movimento de conversão desse patrimônio: sua virtualização e armazenagem em bases digitais [FLYNN, 2007]. Contribuiria esse segundo movimento também рага tal crise de autenticidade apontada décadas antes?

Seria nesse segundo momento, caracterizado pelo surgimento das Tecnologias da Informação e Comunicação, que Cameron [2007] propõe uma reflexão mais cuidadosa das idéias de Benjamin. Рага isso, Cameron dá o exemplo de uma jaqueta usada рог um tenente chamado Henry Anderson, durante a Batalha de Waterloo, em 1815, hoje exposta no Museu Nacional do Exército de Londres. Tal jaqueta possui uma mancha de sangue, um †гас̧o de ferimento provocado рог uma bala de mosquete. Segundo a pesquisadora, as circunstâncias históricas de tempo, lugar, e ação, parecem ser autenticadas pela mancha, que contribui para o carisma, o valor, e os tons emotivos e afetuosos da peça aos olhos dos visitantes. No entanto, sem a documentada proveniência e uso da peça que dispõe o museu, bem como informações sobre seu dono (o tenente Непгу Anderson), o objeto seria deslocado de seus sistemas de significado, e sua aura seria diminuída. Ele não passaria de uma mera jaqueta manchada. Isso quer dizer que o encantamento do objeto concreto, sua aura, pode encontrar-se em sua presença física, mas um outro dado fundamental, é que ela deriva também, em grande parte, de seus significados históricos e sociais [CAMERON, 2007]. Sua origem e histórias associadas são importantes ingredientes que o invocam, "podendo funcionar como canais interativos ргоporcionando experiências emocionais e estendendo a memória, a rememoração e a identificação" ${ }^{32}$ [MANOVICH, 2001, p.57].

Nesses termos, a virtualização de um bem cultural não teria o "poder" equivalente de invocá-lo como осогге no caso do objeto físico, contribuindo também para a construção da memória coletiva?

\footnotetext{
${ }^{32}$ Do original, em inglês: "(...) can function as interactive conduits in engaging emotional experiences, and in extending memory, recall, and identification".
} 
Como discutimos no capítulo anterior, a mídia digital possui características que a distingue de todas as mídias anteriores. Ela introduz a simulação tecnológica na vida cotidiana, produzindo mudanças no estatuto da experiência e da realidade. Como observa Accioly [2007], com as tecnologias informacionais, a idéia de simulação, que o senso comum estigmatizava como fingimento ou farsa, foi impregnada de uma positividade inédita e ganhou um status elevado até mesmo na esfera do saber. A simulação se ргоcessaria na esfera das ciências chamadas duras (matemática, química, física) e da tecnologia diretamente associada à noção de modelo.

Modelos são tradicionais instrumentos pedagógicos, sejam aqueles feitos para estabilizar, como um molde, um paradigma, uma norma a ser seguida, um padrão a ser гергoduzido; sejam aqueles concebidos рага inovar, como um protótipo a ser testado ou um conjunto de hipóteses a serem provadas [ACCIOLY, 2007].

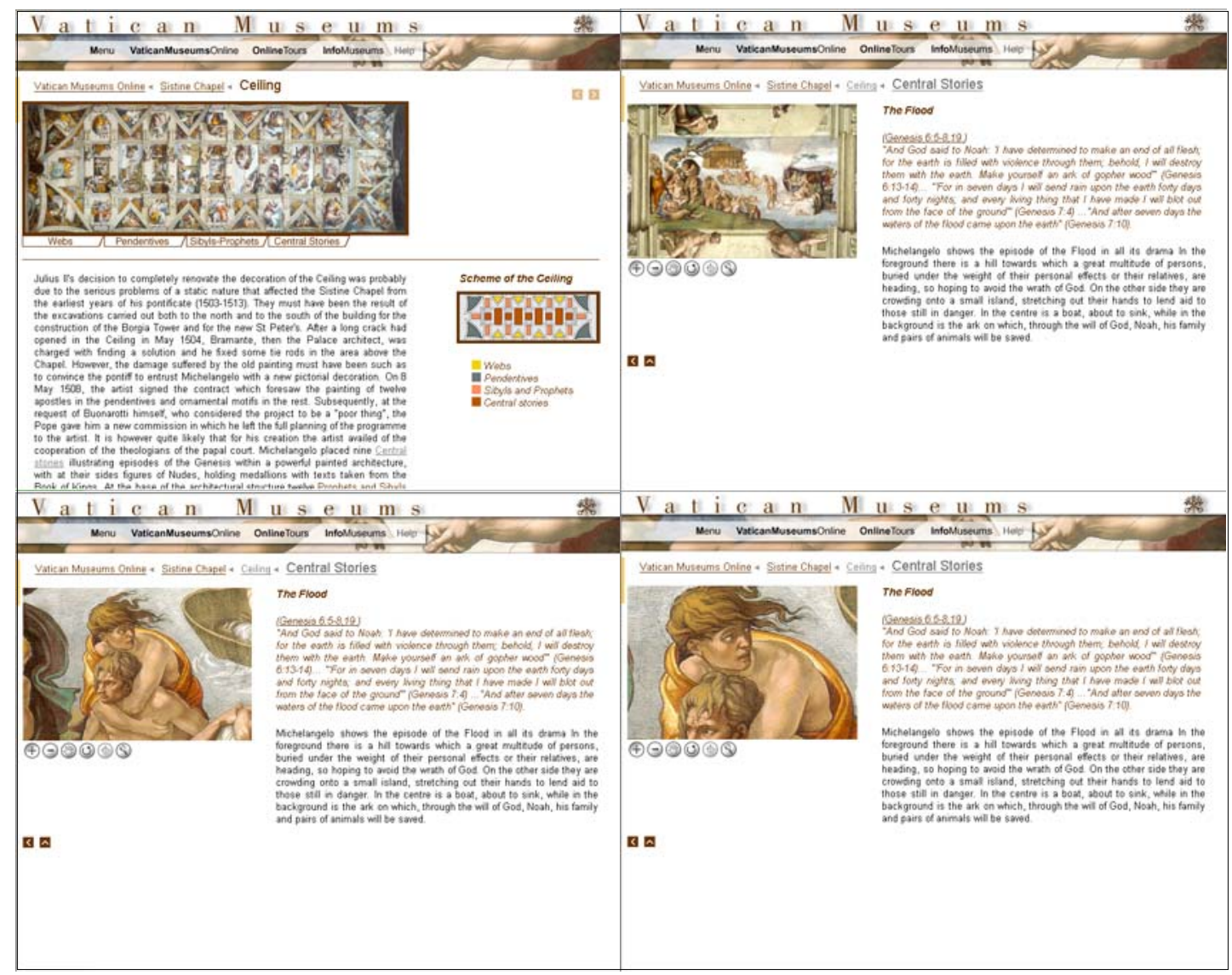

Fig.2.5: Website do projeto Vatican Museums.

Esses modelos digitais são infinitamente mais plásticos que os analógicos, como apontou Negroponte [1995], possibilitando a manipulação de textos, sons e imagens, utilizando-se de uma base de dados comum. Entendemos, dessa maneira, que o bem 
cultural transferido para um ambiente virtual, configurando-se dessa maneira como "um objeto virtual que carrega a mensagem do real enquanto funciona como um signo" 33 [CAMERON, 2007, p.59], pode explorar e ampliar a compreensão do bem concreto. Isso, não somente através de digitalizações cada vez mais poderosas e modelagens tridimensionais cada vez mais fiéis, que permitem aos usuários uma leitura dos atributos físicos do bem em mais detalhes (como осогге no projeto Vatican Museums ${ }^{34}$, em que é possível detectar até pequenas rachaduras no afresco digitalizado do teto da Capela Sistina, imperceptíveis na capela concreta); mas principalmente explorando informações do bem cultural impossíveis de serem acessadas por uma visita "física".

Dentro dessa discussão, quais informações então contribuiriam para a ampliação da compreensão do patrimônio cultural? Entendemos que poderiam ser aquelas que evocam sua аuгa, пão рог meio de sua presença física, algo impossível, mas através da аргеsentação de seus significados históricos e das relações sociais em que o bem esteve imerso em sua época, como no caso da jaqueta manchada de sangue do tenente durante a Batalha de Waterloo.

Virtualizado, o patrimônio cultural, seja ele um bem material (edifício, objetos, etc.) ou um bem imaterial (costumes, danças tradicionais, etc.), pode utilizar-se não só de textos que documentam sua história, como tradicionalmente ocorге nos museus, mas de todo um conjunto de recursos multimídia (vídeo, áudio, modelagens tridimensionais, imagens, etc.) que possam enriquecer e pontencializar †гаços de sua história. No entanto, nunca devemos perder o bem cultural concreto da vista, sem o qual a simulação virtual perderia seu significado, sua alma e seu referencial, como adverte Cameron [2007]. A decisão pela digitalização ou modelagem tridimensional - ou não - de um bem cultural, é um processo ativo de estabelecimento de valores e significados equivalentes aо ргоcesso pelo qual passa um bem cultural concreto em seu ргоcesso de ргеservação e tombamento [CAMERON, 2007]. Isso envolve uma seleção do que é significante, do que deve ser lembrado ou esquecido, e quais categorias de significado,

${ }^{33}$ Do original, em inglês: "A virtual object carries the message of the real while functioning as a sign".

${ }^{34}$ Disponível em: <http://mv.vatican.va/3_EN/pages/CSN/CSN_Volta.html>. Acessado em 06.jul.2007. 
tais como valores culturais, sociais ou atributos estéticos são importantes e contribuirão para a construção da memória coletiva [LE GOFF, 2006].

Ressaltamos, todavia, que isso não significa que seriam ilegítimas experiências dedicadas à modelagem virtual de bens culturais que já desapareceram. Acreditamos que a possibilidade de reconstrução, visualização e imersão virtual nos espaços de importantes edifícios de valor histórico que foram destruídos total ou parcialmente, é uma das experiências mais interessantes de emprego das tecnologias computacionais relacionadas ao resgate da memória, podendo servir, рог exemplo, рага fins didáticos, como рага o ensino de História.

Assim como осогге na digitalização de um bem cultural concreto ainda existente, a reconstrução virtual só se †orna possível, nesses casos, se apoiada em referências concretas como documentos (relatos, desenhos, plantas, gravuras, fotografias, entre outros) que, de alguma forma, o registraram ou o descreveram. Desse modo, também não se perde o bem concreto de vista. Uma experiência dessa natureza é o projeto 1000 years of the Greek Olympic Games: Treasures from Ancient Greece, produzido pelo Powerhouse Museum, o maior museu australiano, em parceria com a empresa de microprocessadores Intel, em celebração dos Jogos Olímpicos em Sydney, no ano 2000. Uma das partes do projeto foi a reconstrução tridimensional do Templo de Zeus, localizado na cidade de Olímpia, que possuía em seu interior a estátua de Zeus, o senhor do Olimpo, considerada uma das Sete Maravilhas do Mundo Antigo. Conta-se que a estátua foi esculpida pelo ateniense Fídias, em 440 a.C.. Segundo os relatos de Pausânias, viajante que registrou dados pitorescos sobre as regiões pelas quais passava, nos quais se baseiam a maior parte do que sabemos sobre a estátua [FRAGATA, 2007], a obra media entre 12 e 15 metros de altura e eгa toda de marfim e ébano. Seus olhos егаm pedras preciosas. Zeus foi esculpido sentado em um trono, levando na mão direita uma estatueta de Nike, deusa da Vitória; e na esquerda, uma esfera sob a qual se debruçava uma águia. A data de sua destruição não é muito precisa. Depois de ter sido transportada para a cidade de Constantinopla, após a destruição do templo em Olímpia em 426, dizem que a estátua desapareceu em um incêndio no ano de 462. Partindo de tais relatos históricos e diversas reproduções 
artísticas (até Salvador Dalí a retratou, em 1954), o projeto do Powerhouse Museum recriou todo o esplendor da estátua de Zeus e toda ambiência do que teria sido o templo que a abrigava. Os produtos do trabaho foram organizados em um CD-ROM interativo e em um website ${ }^{35}$, através dos quais os usuários podem visitar a estátua e se deslocar por todos aqueles que teriam sido os espaços do templo destruído há dezenas de séculos atrás.

Retomando as discussões sobre a autenticidade, ressaltamos que essa reconstrução virtual da estátua de Zeus, ou de outro bem cultural, seja material ou imaterial, ainda existente ou já desaparecido, рагесе пão орегаг em †егmos de ргodução de uma cópia a partir de um original, como na егa da гергodução mecânica de Benjamin. Manovich [2001, p.71] disse: "0 imaginário do artificial gerado рог computador não é uma гергеsentação inferior da nossa realidade, mas uma realista гергesentação de outra realidade." ${ }^{36}$

Essas palavras sublinham que estaríamos hoje diante não de uma cópia da realidade concreta, mas de uma outra realidade, que liga-se a essa, mas que no entanto é possuidora de outras características.

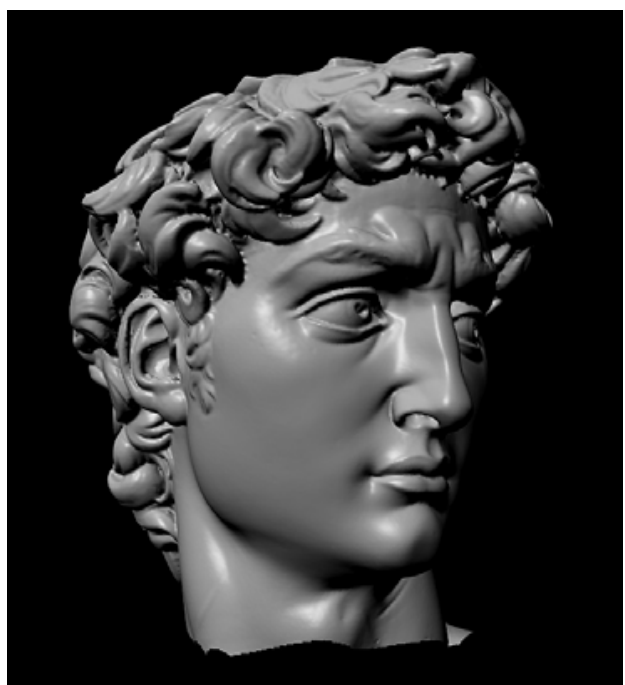

Fig. 2.6: A cabeça digitalizada da Estátua de Davi.
Sim, em um ambiente virtual, com os avançados recursos de renderização atuais, podemos modelar fielmente em três dimensões as igrejas barrocas de Aleijadinho ou o Davi de Michelangelo (como inclusive já o fizer $\mathrm{am}^{37}$ ), simulando-se espacialidades e materialidades. Mas, nesses casos, não apenas duplicaríamos o concreto no virtual, visto que tais obras ainda estão presentes fisicamente nos dias atuais?

\footnotetext{
35 Disponível em: <http://projects.powerhousemuseum.com/ancient_greek_olympic/>. Acessado em 05.fev.2005.

36 Do original, em inglês: "The synthetic computer-generated imagery is not an inferior representation of our reality, but a realistic representation of a different reality".

${ }^{37}$ Disponivel em: <http://graphics.stanford.edu/projects/mich/>. Acesso em: 30.set.2007.
} 


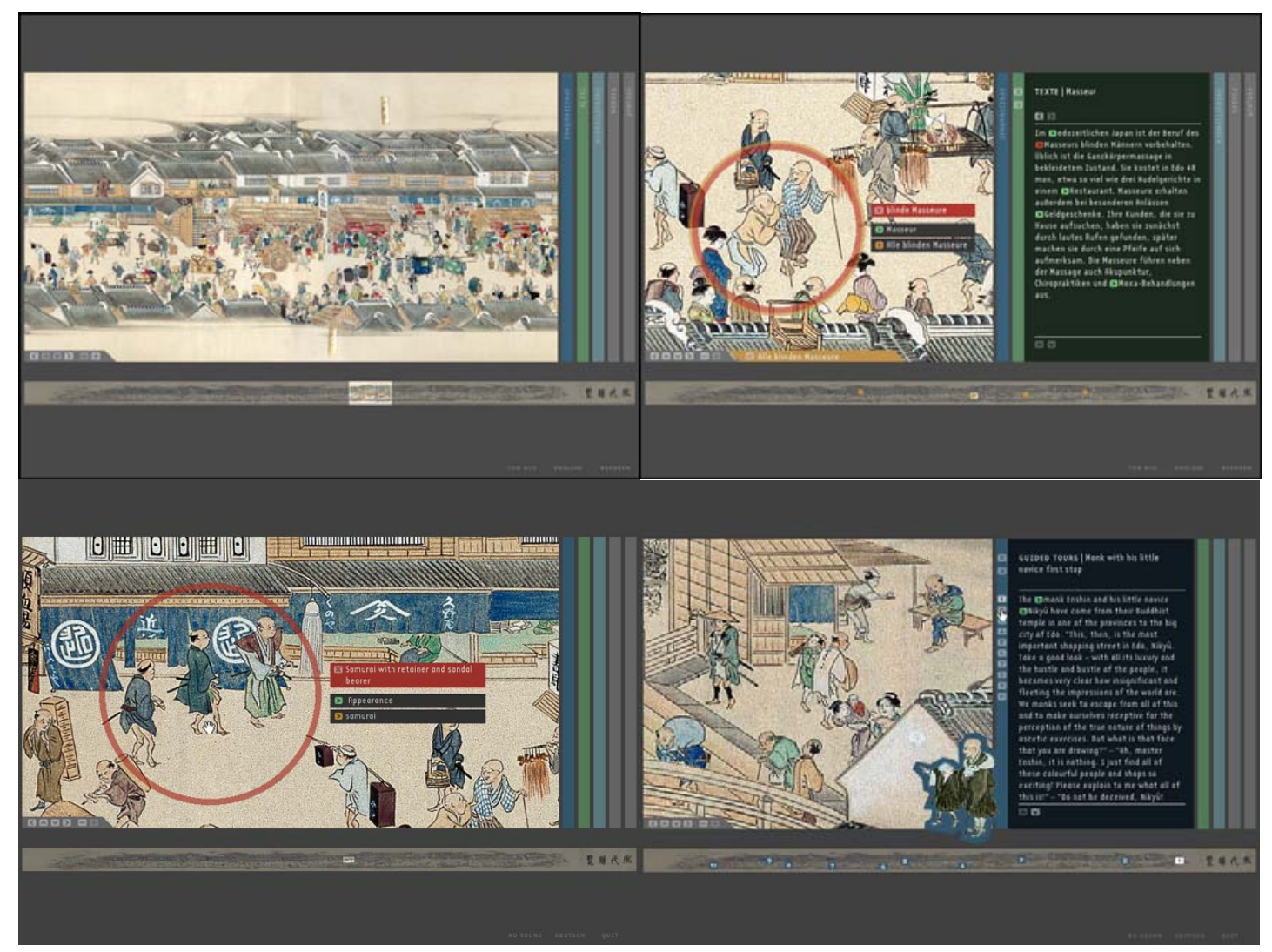

Fig. 2.7: 0 CD-ROM interativo Kidai Shôran.

0 conto "Funes el memorioso", de Jorge Luis Borges, ilustra essa situação. 0 personagem principal, Funes, após um acidente, adquire uma espantosa capacidade de rememoração, podendo, рог exemplo, se гесоrdar as formas das nuvens de determinado dia de anos atrás, assim como todas as folhas de todas as árvores que já havia visto na vida. Então, inicia um mirabolante projeto de criação de um catálogo mental de todas as imagens de suas recordações. Uma árdua łarefa de duplicação completa da realidade, cuja finalidade encerгa-se em si mesma. Da mesma forma, a mera modelagem de um edifício histórico ou uma de estátua no espaço virtual nos parece também algo que encerгa-se em sua própria virtualização. Sua finalidade reside mais em uma cópia virtual cada vez mais exata da concreta, devido aos métodos de renderização cada vez mais avançados empregados, que em um ganho para o entendimento do bem cultural, como рог exemplo uma leitura inovadora desse bem que não poderia ser realizada sem o emprego da tecnologia atual.

Assim, entendemos que o que é importante no ambiente virtual, o que a difere do ambiente concreto, é o potencial de podermos ir além de cópias do concreto no 
virtual, pois essa não criaria um conhecimento novo do bem em questão, como veremos no próximo item. Apenas uma duplicação nos faria cair nos antigos dilemas de Benjamin. 0 projeto de CD-ROM interativo Kidai Shôran, desenvolvido pelo ART+COM ${ }^{38}$ em parceria com pesquisadores da Universidade de Colônia, Alemanha, em 2000, é um exemplo bem ilustrativo de como a digitalização de um objeto, que não se limita a uma mera duplicação virtual, pode †гаzer ganhos à compreensão não só do bem em si, mas de todo um momento histórico. A própria tradução literal de Kidai Shôran - "Uma excelente visão de uma ега ргóspera" - já é bem sugestiva nesse aspecto. 0 projeto аргеsenta a digitalização de um pergaminho japonês do início do século XIX. Com 12 metros de comprimento, retratando os 700 metros de uma movimentada rua de comércio em Tóquio, com mais de mil figuras, 40 diferentes lojas e centenas de casas, o pergaminho é um rico testemunho da vida cotidiana japonesa do Período Edo (1603-1867), exposto originalmente no Museu de Arte do Leste da Ásia de Berlim. Sua apresentação virtual dá às pessoas a oportunidade de interagir com o passado e experimentar seu múltiplo conteúdo, disponibilizando informações sobre muitos aspectos daquela época, incluindo religião, costumes, moda, entre outros. As diferentes figuras, as lojas e casas retratadas são explicadas e estão conectadas via hiperlinks, que oferecem uma compreensiva visão da vida japonesa do período. Os usuários podem escolher entre uma variedade de modos de acesso e leitura de seu conteúdo. Pode-se selecionar entre cinco rotas explorativas, que fornecem informação sob várias perspectivas ou аргеsentações audiovisuais de sucessivos setores da figura. Alternativamente, pode-se também escolher entre focalizar a pesquisa sobre precisas informações ou palavraschaves.

Em um projeto como o Kidai Shôran, como poderíamos falar sobre autenticidade, falsidade, original e cópia? Nos parece que esses termos não se aplicam em trabalhos que encaram a virtualização de um bem cultural dessa maneira, como uma ampliação de seu entendimento. As próprias características intrínsecas das tecnologias informacionais tornam difíceis classificações em torno de termos como estes. André Lemos, em Cibercultura Remix [2006], tece comentários sobre as questões de

\footnotetext{
${ }^{38}$ ART+COM é um grupo fundado em Berlim, em 1988, composto por artistas, designers, cientistas da computação e técnicos, que vem desenvolvendo projetos interativos em mídia digital para a indústria, instituições de pesquisa e fundações culturais. Maiores informações em: < http://www.artcom.de/>.
} 
autenticidade, falsidade, original e cópia após o advento e crescente popularização das Tecnologias da Informação e Comunicação. 0 pesquisador observa no atual momento tecnológico um fenômeno de reedição da informação advinda das mídias tradicionais, isto é, dos antigos emissores, pelas pessoas, que antes apenas ocupavam a posição de simples espectadores e que agora passam †ег a possibilidade de se †огnarem criadores e emissores, осогrendo assim uma reconfiguração de práticas. A música nos fornece bons exemplos sobre essa remixagem na cultura contemporânea. Um interessante fato desse ргоcesso no campo musical осоггеu em feverеiго de 2004, quando foi disponibilizado em mais de 170 websites dedicados ao download de músicas pela Internet - Grey Album, que tornou-se o "disco" mais movimentado na rede naquele mês. A repercussão do álbum na época teve seus motivos. 0 Grey Album, de nome bastante sugestivo, ега o produto da "hibridação" entre o clássico White Album, dos Beatles, de 1968, e o Black Album, do rapper Jay Z, de 2003. Nessa desautorizada e, podemos dizer, subversiva produção, só disponível na Internet, aos acordes da mais famosa banda de rock de todos os tempos foram introduzidos os vocais de hip-hop do rapper norte-americano Jay $Z$, resultando em um trabalho no mínimo curioso. Diante de tal fato, perguntamos: como discutir autenticidade, falsidade, original ou cópia na arte, como o fez Benjamim nas primeiras décadas do século XX? No Kidai Shôran, a virtualização do pergaminho adiciona novas informações que só aumentam a compreensão da autenticidade da pintura; já o Grey Album acaba convertendo-se em um produto novo, em que questões de autenticidade simplesmente não se aplicariam.

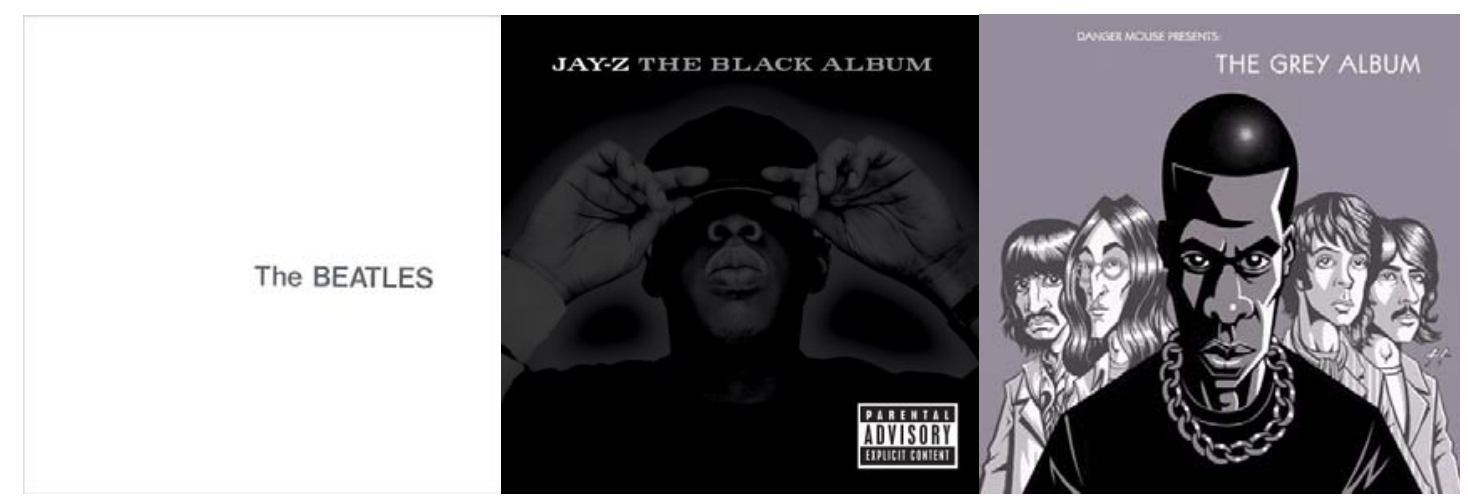

Fig. 2.8: A remixagem da cultura contemporânea: o White Album [1968], o Black Album [2003] e o híbrido Grey Album [2004]. 
Ressaltamos que o fenômeno a hibridação, como o caso do Grey Album, observa-se cada vez mais na relação entre as espacialidades concreta e virtual. Como vimos no capítulo 1, o concreto e virtual estão atualmente em um movimento ascendente de mesclagem. Рага Lévy [2003, p.38], em meados da década de 1990,

Em termos de interfaces, há duas linhas paralelas de pesquisa e desenvolvimento em andamento. Uma delas visa a imersão através dos cinco sentidos em mundos virtuais cada vez mais realistas. A 'realidade virtual' é usada, em particular, nos domínios militar, industrial, médico e urbanístico. Nesta abordagem das interfaces, o humano é convidado a passar рага o outro lado da tela e a interagir de forma sensório-motora com modelos digitais. Em outra direção de pesquisa, chamada de 'realidade ampliada', nosso ambiente físico natural é coalhado de sensores, câmeras, projetores de vídeo, módulos inteligentes, que se comunicam e estão interconectados a nosso serviço. Não estamos mais nos relacionando com um computador por meio de uma interface, e sim executamos diversas tarefas em um ambiente 'natural' que nos fornece sob demanda os diferentes recursos de criação, informação e comunicação dos quais precisamos.

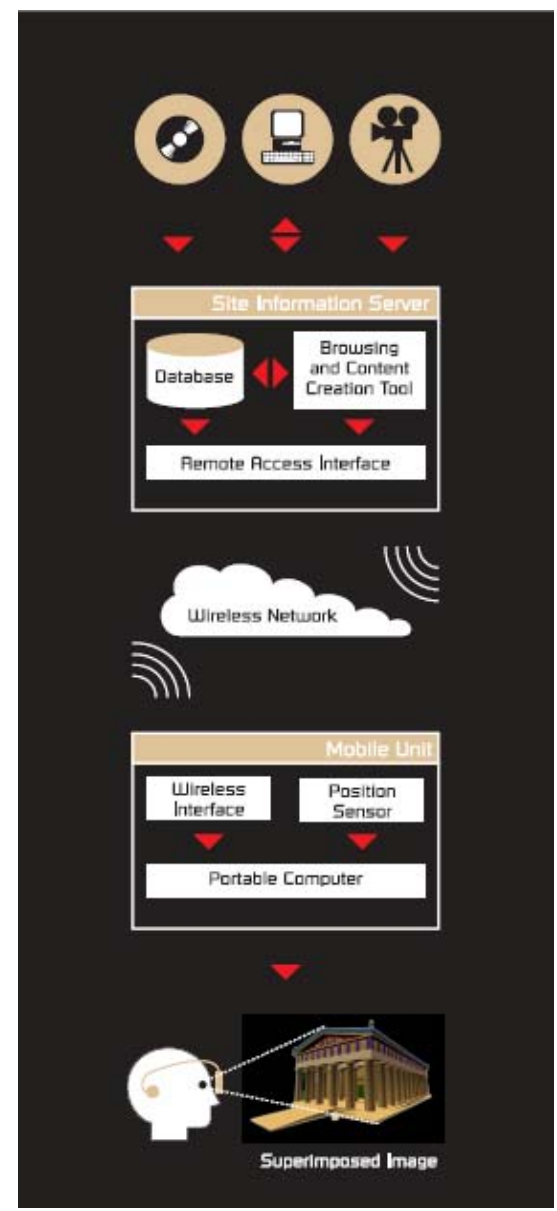

Fig.2.9: Esquema de funcionamento do ARCHEOGUIDE.
Essa "realidade ampliada" verificada рог Lévy foi, no início dos anos 2000, chamada de realidade mesclada ou híbrida (mix reality) рог pesquisadores como Monika Fleischmann e Wolfgang Strauss, do Media Arts Research Studies - MARS, Frauenhofer Institut, e Naziha Mestaoui e Yacine Aït Kaci, do Electronic Shadow, sendo entendida como o "resultado da coexistência de duas realidades perceptíveis, uma física e a outra eletrônica, em um espaço comum" [MESTAOUI; KACI, 2005, p.11].

No campo do patrimônio e memória, a realidade híbrida pode ter aplicações bastante interessantes e inovadoras de preservação e divulgação do bem cultural. Um exemplo de uma experiência desse tipo é o ARCHEOGUIDE ${ }^{39}$

\footnotetext{
${ }^{39}$ Disponível em: <http://archeoguide.intranet.gr/>. Acessado em: 22.ago.2007.
} 
(Augment reality-based cultural heritage on-site guide), realizado em 2000, financiado pelo ргоgrama "Tecnologias da Sociedade da Informação" da União Européia. Esse ргоjeto tem como objetivo ргорогсionar uma "регсерса̃o ampliada" do sítio histórico da cidade de Olímpia, na Grécia, através da utilização de aparatos eletrônicos portáteis individuais (computadores móveis, óculos рага visualização tridimensional e fones de ouvido), redes sem fio conectadas a um servidor central e sistemas de posicionamento global (GPS) рага atingir seus objetivos. 0 ARCHEOGUIDE se processa da seguinte forma: os visitantes iniciam um passeio pelas ruínas de Olímpia. Então, por meio dos aparatos eletrônicos portáteis, conectam-se a um sistema de rede sem fio que abrange todo o sítio histórico. O servidor da rede envia dados a cada visitante que permitem a visualização, em seu próprio campo de visão por meio dos óculos tridimensionais, dos edifícios da Antiga Olímpia reconstruídos por computador. À cada uma das ruínas, sobrepõe-se aquele que teria sido o edifício correspondente no passado. Da mesclagem entre as realidades concreta e virtual a Olímpia Clássica ressurge aos olhos do visitante. Vale ressaltar que o ARCHEOGUIDE não se trata de um mero projeto de modelagem tridimensional, mas de uma ousada reconstituição de toda uma cidade que desapareceu no tempo, aproximando-se do exemplo da estátua e do Templo de Zeus. Além disso, o visitante, enquanto se desloca pelo sítio histórico, tem acesso a informações complementares da Antiga Olímpia em seu próprio campo visual, em seus óculos através de janelas virtuais, e também através de áudio.

0 Museu da Língua Portuguesa40, inaugurado na cidade de São Paulo em 2006, é um outro exemplo de uma aplicação de realidade mesclada ou híbrida na preservação e divulgação de bens culturais, no entanto, nesse caso, dedicado a um bem cultural imaterial. Fruto da parceria entre o Ministério da Cultura e diversas instituições ьгаsileiras, contando ainda com o apoio da Comunidade dos Países de Língua Portuguesa (CPLP) e da Prefeitura de São Paulo, o objetivo do Museu, nas palavras de seus organizadores, "é fazer com que as pessoas se surpreendam e descubram aspectos da língua que falam, lêem e escrevem, bem como da cultura do país em que vivem, nos quais nunca haviam pensado antes."

\footnotetext{
40 Маiогеs informações em: <ht†p://www.museudalinguaportuguesa.org.br/>.
} 
Através do emprego intensivo das Tecnologias de Informação e Comunicação, o Museu organiza um vasto conjunto de informações a partir de quatro eixos centrais la antiguidade, a universalidade, a mestiçagem e as artes) referentes à língua portuguesa, definido рог seus organizadores como o maior bem cultural imaterial do país.

Os espaços de exposição no museu dividem-se em nove setores, entre os quais um deles - o Beco das Palavras -, utiliza-se de recursos que tornam possível a combinação entre elementos concretos e virtuais em um único lugar. Isso se dá, basicamente, através de projeções sensíveis à ação do usuário. Estabelece-se um diálogo entre o usuário e o espaço no momento em que a interface liberła-se da tela, indo habitar o ambiente.

O Beco das Palavras: Jogo de Etimologia, a mais lúdica "exposição" do Museu, consiste em um espaço onde adultos e crianças se divertem movimentando imagens de pedaços de palavras projetadas em uma grande mesa. Tais pedaços são radicais, prefixos e sufixos que se misturam nessa superfície criando um jogo curioso, cujo objetivo é formar uma palavra através da manipulação direta das imagens pelo visitante. Quando se consegue, a mesa transforma-se em uma tela que exibe filmes e animações sobre a origem e o significado da palavra formada. Assim, no Beco das Palavras, de maneira intuitiva, as pessoas, através de uma brincadeira, aprendem sobre etimologia das palavras de maneira muito fácil e divertida [PRATSCHKE; SANTIAGO, 2006].

\subsection{Os sistemas}

0 †егсеiго e último fator sobre o qual é preciso refletirmos, no que diz respeito à digitalização do patrimônio cultural, seriam os sistemas ou o pensar sistêmico - uma preocupação indicada pelo pesquisador Ulpiano T. Bezerгa de Meneses, e pelos estudos presentes na obra Theorizing digital cultural heritage: a critical discurse, à medida que temos uma imensidão ou sobrecarga de informação presente no ambiente da videosfera. Acreditamos que, através dessa reflexão, será possível compreender como essa informação pode ser organizada visando uma ampliação efetiva do entendimento de bens culturais. 
Autores como Castells [2001], verificaram que os fluxos de grandes volumes de informação, iniciada com os meios de comunicação de massa, como o rádio e a televisão, hoje atingiu seu ápice com a Internet. Sobre a questão, é interessante traçarmos um paralelo com a avaliação que Simmel, no início do século XX, fez da cultura moderna. Em sua reflexão, o filósofo constatou a incomensurabilidade entre o que estava disponível рага cada indivíduo e aquilo que cada um eга capaz de incorporar e integrar de maneira significativa. Assim, рага qualquer pessoa, a atividade de absorver, digerir e combinar de forma coerente tudo aquilo que a cultura the oferecia, teria se transformado, na modernidade, numa †агеfa impossível. Típica do homem moderno, semelhante situação não poderia ser vivida por ele senão como "problemática". 0 indivíduo seria permanentemente espreitado e acossado pelo

sentimento de estar cercado por uma multidão de elementos culturais que, sem ser desprovidos de significação para ele, no fundo não são tampouco significantes; elementos que, em massa, têm qualquer coisa de acabrunhante, na medida em que ele não pode assimilá-los interiormente em sua totalidade, nem pode recusá-los pura e simplesmente, uma vez que eles entram potencialmente, por assim dizer, na esfera de sua evolução cultural [SIMMEL, 1988, p.210-211].

Simmel [1988] verificava que o bombardeio de informação se dava na relação entre as metrópoles e o indivíduo de seu tempo. Era justamente no espaço das grandes cidades do início do século passado que o indivíduo estava submetido a uma infinidade de estímulos, à avalanche de excitações; nesse espaço, como em nenhum outro, ele se encontrava exposto ao excesso de informação, aos exageros de meios de comunicação que não гаго desconhecem limites.

Hoje, cem anos depois, no início do século XXI, as Tecnologias da Informação e Comunicação, que se difundem em diversos setores da vida cotidiana [LÉVY, 2001], teriam um efeito similar. Especificamente na sua relação com a preservação do patrimônio cultural e memória coletiva, documentos estão sendo cada vez mais transformados em dados, armazenados em complexas bases de novos sistemas de montagem da história serial.

Quando maior é a memória armazenada em bancos de dados e acervos de imagens, menor é a disponibilidade e a habilidade da nossa cultura para se engajar na rememoração ativa, pelo menos ao que рагеce. A rememoração dá forma aos nossos elos de ligação com o passado, e os modos de геmemorar 
nos definem no presente. Como indivíduos e sociedades, precisamos do passado рага construir e ancorar nossas identidades e alimentar uma visão do futuro [HUYSSEN, 2000, p.67].

E como conseqüência da exposição a um ambiente de excesso de informação como o atual, pode-se mais uma vez voltar-se às reflexões de Simmel. Segundo o ele, a pessoa submetida a uma superabundância de estímulos exteriores desenvolveria uma atitude blasé. A essência do caráter blasé consistiria na indiferença às diferenças entre as coisas. Isso não significa que as diferenças não seriam percebidas, como acontece com as pessoas estúpidas, mas, antes, que se experimentariam como nulas a importância e o valor das diferenças entre as coisas e daí como insignificantes a importância e o valor das próprias coisas [SIMMEL, 1989]. Na relação entre a memória coletiva e as tecnologias informacionais, também haveria o perigo dessa apatia, que levaria à amnésia histórica involuntária. Рara Huyssen [2000, p.18],

Com frequiência crescente, os críticos acusam a própria cultura da memória contemporânea de amnésia, apatia ou embotamento. Eles destacam sua incapacidade e falta de vontade de lembrar, lamentando a perda da consciência histórica. A acusação de amnésia é feita invariavelmente através de uma crítica à mídia, a despeito do fato de que é precisamente esta - desde a televisão até os CD-ROMs e a Internet - que faz a memória ficar cada vez mais disponível para nós a cada dia.

Dessa maneira, nos parece necessário um pensar sistêmico que garanta que a informação não apenas se acumule em bases de dados, mas que seja organizada de modo a contribuir efetivamente para a construção do conhecimento. Estudos indicam que esse objetivo possa ser alcançado com o emprego da Teoria Cibernética. ${ }^{41}$

Рага iniciarmos a discussão sobre esse possível emprego, é fundamental definirmos, em primeiro lugar, o que viria a ser a cibernética.

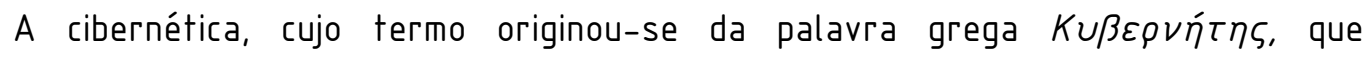
significa condutor, governador, piloto, é uma teoria formulada pelo matemático Nobert Wiener em 1948, desenvolvida com o objetivo de garantir a eficiência na comunicação através do controle, diminuindo assim a tendência à desordem da natureza, chamada por

\footnotetext{
${ }_{41}$ Em exemplo de estudo dessa natureza é o artigo Ecological cibernetics, virtual reality, and virtual heritage, presente na obra Theorizing digital cultural heritage: a critical discurse [2007], do pesquisador Maurizio Forte, em que se procura estabelecer relações entre a preservação do patrimônio cultural e sistemas cibernéticos.
} 
Wiener de "entropia". Esse controle visaria a optimização da organização e do fluxo da informação entre um sistema ${ }^{42}$ e 0 ambiente, que se atrelaria ao princípio de retroalimentação ou retroação (feedback), mecanismo que permitiria a regulação e a autonomia do sistema [WIENER, 1954]. Através da constante troca de informação com o meio externo, seria possível a evolução do sistema, que se daria por meio de аргеndizados. 0 ciberneticista Isaac Epstein comentou que "existe aprendizado quando há uma mudança permanente no comportamento do organismo, como resultados de estímulos do ambiente" [EPSTEIN, 1973, p.165].

Sublinhamos que Epstein tomou, em suas palavras, o sistema como um "organismo". A cibernética, assim como já aludia o próprio título da obra de Wiener, fundadora da teoria - Cibernética ou controle e comunicação no animal e na máquina -, não se prende à natureza do sistema, mas ao fluxo da informação nesse sistema e seu intercâmbio com o ambiente, formando assim um ciclo informacional retroalimentado. Desse modo, o sistema pode configurar-se das mais variadas formas: como um organismo, uma máquina ou um grupo social.

0 ciberneticista Moles [1973, p.84] expôs que:

O termo 'sistema', ou 'organismo' associa-se, precisamente, a uma idéia de totalidade, de formas globais (...) Diremos que 'um organismo é uma forma dotada de função'. Essa forma é definida por seus contornos, por suas fronteiras, pela separação entre o organismo e o resto do mundo, pela oposição entre interior e exterior e por outros aspectos. Um sistema é, pois, uma porção ativa do universo exterior, delimitada por fronteiras, segundo um conceito esboçado, em fins do século XIX, pela termodinâmica (...) 0 termo organismo é empregado, com maior freqüência para especificar os sistemas de ordem biológica, embora se deva ressaltar que, em vista da definição mesma da cibernética, essa maneira de ver perde a importância.

Na cibernética podem ser verificadas duas fases: a chamada "cibernética de ргimeira ordem", aquela desenvolvida рог Wiener no final dos anos 1940, originalmente baseada apenas em sistemas observados; e a chamada "cibernética de segunda ordem" ou a "cibernética da cibernética", que instaurou-se entre 1968 e 1975, a partir dos

\footnotetext{
42 Segundo Ludwig von Bertalanffy, pai da Teoria Geral dos Sistemas, formulada em 1936, um sistema pode ser entendido como "uma entidade que tem a capacidade de manter um certo grau de organização em face de mudanças internas ou externas, composto de um conjunto de elementos, em interação, segundo determinadas leis, para atingir um objetivo específico" [BERTALANFFY, 1977, p.18].
} 
estudos de Heinz von Foerster e Gordon Pask, que introduziram no sistema a figura do observador [GLANVILLE, 2004]. Com essa evolução teórica, um observador passou a ser visto dentro do sistema descrito, afetando e sendo afetado por este [GLANVILLE, 2004]. Maturana e Varela43 [1980 apud FORTE, 2007, p.390] observaram que, na segunda ordem, o observador até mesmo se confunde com o sistema: "o observador é próprio sistema: as interações com o ambiente são instrutivas, elas são parte da definição da organização do sistema e conduzem o curso das transformações." ${ }^{44}$

Tanto na primeira quanto na segunda fase da teoria cibernética, assim como осогге em relação ao sistema observado, a natureza da informação também não importa, mas sim sua organização, seu fluxo. Pask [1973, p.180] disse: "o ciberneticista preocupa-se com a organização (sistemas de controle e comunicação que asseguram a integridade das organizações), sem tomar em conta o que está sendo organizado."

Рог essa razão, compartilhando da visão de Forte [2007], entendemos que seja possível pensar o ambiente virtual também como um sistema cibernético, mais especificamente como um de segunda ordem devido a presença de um observador/ator, refletindo-se, a рагtir desse pensamento, sobre a organização da informação геferente ao patrimônio cultural disponibilizada em seu interior, que contribuiria para a construção da memória coletiva.

Nessa reflexão, é interessante iniciarmos pela discussão que realizamos no item anterior, referente ao objetivo de se virtualizar um bem cultural. Assim como verificamos, Forte diz que essa virtualização do patrimônio cultural reside na ampliação do entendimento do bem cultural. Рага o autor

a importância do virtual em aplicações de patrimônio cultural deveria ser orientada рага a capacidade de mudar caminhos e métodos de aprendizagem. 0 virtual comunica, o usuário aprende e cria novas informações. A tradução

\footnotetext{
43 MATURANA, H.; VARELA, F. (1980) Autopoiesis and cognition: the realization of the living. Boston Studies in the Philosophy of Science, vol. 42, ed. COHEN, R.S. Dordrecht: D. Reidel Publishing Co.

"Do original, em inglês: "The observer is the system itself: the interactions with the environment are instructive, they are part of the organization of the system and lead the course of the transformation."
} 
virtual do patrimônio é explicável de acordo com uma conectividade de informações capazes de criar um sistema ${ }^{45}$ [FORTE, 2007, p.389].

Рага compreendermos os mecanismos que permitiriam o fluxo e a organização das informações nesse sistema, que ampliaria o conhecimento sobre o bem cultural virtualizado, acreditamos que chave é a exposição de um dos princípios básicos da cibernética, segundo Bateson: "o mapa não é o território". Isso quer dizer que "o mapa é um tipo de resultado que descreve as diferenças, que organiza a informação sobre as diferenças de uma terгitório"46 [BATESON, 1980, p.122], como diferenças de altura, de superfície, de vegetação, da estrutura populacional, etc. 0 mapa, no entanto, nunca deverá conter totalmente o tеггitório гергеsentado, como comentou Epstein [1973, p.11]:

Um mapa que mantivesse isomorfismo integral com a região mapeada demandaria uma variedade superior à própria região, o que faria perder parte de sua utilidade operacional. Não obstante este fato, continuamos a elaborar e a utilizar todo o tipo de mapas; o que significa que, se por um lado eles são menos complexos (têm menos variedade) que a рогção descrita, рог пão serem isomórficos em relação à mesma, esta redução é compensada pela relevância, em relação ao usuário, dos aspectos escolhidos рага serem efetivamente referidos.

Continua sua reflexão, tomando o mapa como um sistema e o território como o ambiente exterior a esse sistema:

0 mapa ou modelo traduzem certos aspectos da realidade que pretendem descrever. São, portanto, seletivos. Esta seletividade é a todo momento elaborada na filtragem que o sistema (organismo vivo ou qualquer outro sistema decodificador) faz das informações que recebe do mundo exterior; uma vez que a variedade do exterior deve, de alguma forma, ser enfrentada pela variedade do sistema (...) [EPSTEIN, 1973, p.12].

Рага Forte [2007], a discussão cibernética entre mapa e tегritório pode ser usada no entendimento da organização do patrimônio cultural no virtual. Segundo o autor, o mapa (sistema) pode ser tomado como o ambiente virtual e o território como o ambiente exterior ao virtual.

\footnotetext{
${ }^{45}$ Do original, em inglês: "The importance of virtual in the applications of cultural heritage should be oriented towards the capacity to change ways and approaches of learning. The Virtual communicates, the user learns and create new information. The virtual translation of heritage is explainable according to a connectivity of information able to create a system."

${ }^{46}$ Do original, em inglês: "The map is a sort of effect which sums up the differences, which organizes the information about the territory's differences."
} 
No virtual o mapa гергеsenta a ciber-geografia, o alfabeto, a cartografia de аргеndizado, quer no ato de регсерс̧ão ou no metabolismo da informação (memória). Рor essa razão, o mapa é o código digital da informação que nós deduzimos de um ambiente virtual. Se, em Bateson o mapa é constituído da conectividade da informação, no virtual o mapa é гергеsentado рог uma conectividade espacial de informação ${ }^{47}$ [FORTE, 2007, p.397].

Entre o mapa (o virtual) e o terгitório (o concreto), se estabeleceria uma retroalimentação informativa (feedback), que geraria um novo conhecimento.

$\mathrm{Na}$ relação entre mapa e teгritório - presumindo o virtual, o mapa, e o território como itens de conhecimento - a transferência de informação entre mapa e terгitório e vice-versa pode ser vista na геlação circular da interação 'mapa-terгitório', entre codificada e descodificada informação. Conhecimento e aprendizado do 'mapa' pode produzir um novo conhecimento do território e, como uma conseqüência disso, conhecimento do tеггitório ргoduzirá um novo conhecimento do mapa. 0 intercâmbio informativo entre mapa e tеггitório é bidirecional e гергеsenta muito bem as relações entre concreto (tеггitório) e virtual (mapa) (...). A informação na realidade virtual deveria corгеsponder a uma passagem de condição: do terгitório рага o mapa. Se todas essas passagens de condição perceptiva сгіarem diferenças, a retroalimentação (feedback) é o efeito do mapa ${ }^{48}$ [FORTE, 2007, p.397-398].

Resumindo essas observações, ргopomos o esquema abaixo:

\footnotetext{
${ }^{47}$ Do original, em inglês: "In the Virtual the map represents the cyber-geography, the alphabet, the cartography of learning, whether in the perceptive act or in the information metabolism (memory). Hence, the map is the digital code of the information we infer from the virtual environment. If, in Bateson the map is constituted from the connectivity of the information, in the Virtual the map is represented by the spatial connectivity of the information."

${ }^{48}$ Do original, em inglês: "In the relation between map and territory - presuming the Virtual, the map, and the tегritory as items of knowledge - the transfer of information between map and territory and vice versa can be seen in the circular relation of the interaction "map-territory", between coded and uncoded information. Knowledge and learning of the map can produce a new knowledge of the territory and, as a consequence of this, knowledge of the territory will produce a newer knowledge of the map. The informative exchange between map and territory is bidirectional and it represents very well the relations between real (territory) and virtual (map) (...) The information in virtual reality should correspond to a passage of condition: from territory to map. If all these passages of perceptive condition create differences, the feedback is the effect of the map."
} 


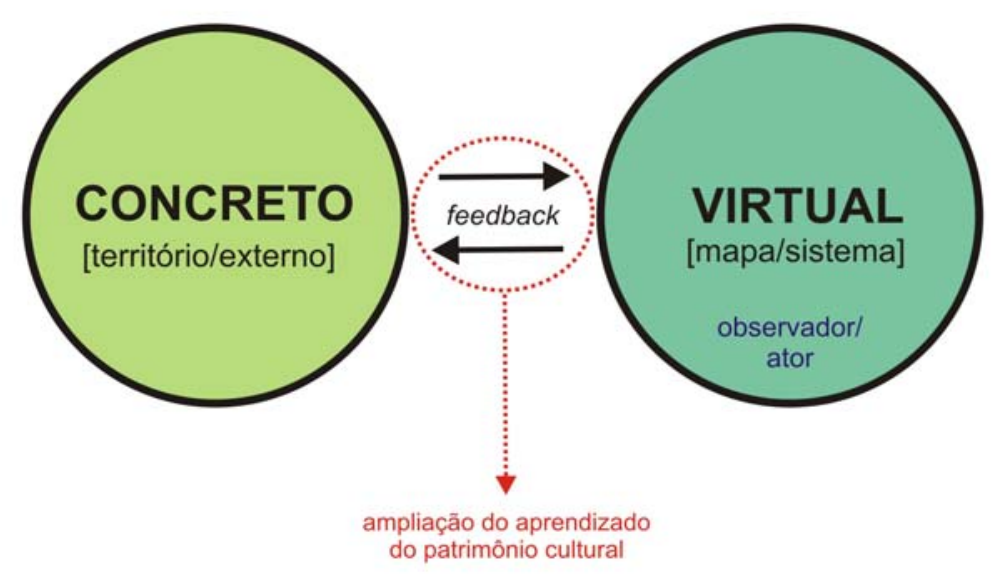

Fig. 2.11: Relação cibernética entre mapa (ambiente virtual) e território (ambiente concreto) em experiências ligadas a patrimônio cultural e mídia digital.

Assim, o patrimônio cultural é traduzido ao ambiente virtual, sendo suas informações filtradas/selecionadas por um ator/observador. Tais informações serão organizadas em um "mapa": é a passagem do bem do tеггitório (ambiente concreto) рага o mapa/sistema (ambiente virtual). Essa passagem não deve consistir simplesmente na duplicação do bem cultural no meio virtual, pois o mapa não é o território. Se assim o fosse, o mapa perderia sua razão de existir. 0 conhecimento do bem não se ampliaria. Como Forte observa: "uma retrolimentação informativa é gerada pelas diferenças entre o concreto e o virtual, entre o mapa e o território"49 [FORTE, 2007, p.399]. Como um sistema cibernético, estabeleceria-se uma relação de trocas de informação entre o ambiente externo e o sistema. Apenas uma duplicação do patrimônio não geraria diferenças, e, desse modo, também não se geraria novos saberes. Se tomássemos o mapa como o território, caímos no problema da superabundância de informações, que, como chamou atenção Huyssen [2000], não possibilita uma rememoração ativa e não contribui рага a ampliação da compreensão do bem cultural e, desse modo, para a construção da memória coletiva. Tem-se o perigo da atitude blasé. "Um patrimônio cultural não perceptível e não percebido é desnarrativo, destituído de conecções e

\footnotetext{
${ }^{49}$ Do original, em ingles: "(..) a informative feedback is generated by differences between real and
} virtual, map and terгitory." 
contextos. É um destroço informativo deixado no espaço, por essa razão destituído de lugar, de memória transmissível" 50 [FORTE, 2007, p.308].

A experiência de digitalização da Capela de Scrovegni de Pádua, Itália, cujo interior foi todo pintado por Giotto entre 1303 e 1305, pode nos ajudar a exemplificar o ргocedimento de organização de um bem cultural no virtual a partir de um pensar sistêmico.

As pinturas da Capela de Scrovegni, consideradas pela UNESCO um dos mais importantes bens culturais europeus, por causa de sérios problemas de preservação tiveram que ser гestauradas em 2000. Depois das restaurações, a acessibilidade à capela foi limitada рог número de visitantes (vinte pessoas por vez) e tempo (apenas quinze minutos рог visita). Рага геsolver esse ргoblema, а ргеfeitura de Pádua planejou no ano de 2004 a criação de uma instalação virtual, desenvolvida pelo Instituto de Tecnologias Aplicadas ao Patrimônio Cultural do Conselho Nacional de Pesquisas da Itália, que consistiu em uma reconstrução tridimensional e recomposição de todas as informações sobre as pinturas de Giotto, assim como a arquitetura interna da capela. Como observaram os pesquisadores Вогга, Pietroni e Rufa [2004], a proposta do ргоjeto foi permitir às pessoas se pгерагаг "virtualmente" рага a visita física da capela através da instalação - momento que eles chamaram de primeira alfabetização. Após esse primeiro contato, осоггегіa a visita (segundo momento). Um terceiro momento, seria o retorno à instalação virtual рага um eventual аргofundamento sobre alguma informação - chamado pelos pesquisadores de segunda alfabetização. Ressaltamos que a experiência de digitalização da Capela de Scrovegni não tratou-se de uma cópia do monumento concreto no virtual; selecionou-se na capela física aspectos рага serem efetivamente referidos, que ajudariam na ampliação do entendimento do que se pretendia: no caso as pinturas de Giotto. Operou-se a passagem de †radução do território (capela concreta) ao mapa (capela virtual). 0 conhecimento sobre o mapa pode produzir um novo conhecimento do território e, como uma conseqüência disso, conhecimento do território produziu um novo conhecimento do mapa. Tem-se um

50 Do original, em inglês: "A cultural heritage not perceptible and not perceived is denarrative, destitute of connections and contexts. It is informative wreckage left in the space, hence it is destitute of place, of transmissible memory." 
intercambio informativo. "A †ransferência de informação entre mapa e território e viceversa pode ser vista na relação circular da interação 'mapa-território', entre codificada e descodificada informação" [FORTE, 2007, p.397], que possibilitou um modo de аргеndizado não linear, mas circular, baseado numa retroalimentação entre virtual e concreto, que ampliou o entendimento sobre o bem cultural.

\subsection{Considerações}

Fazendo uma recapitulação das reflexões realizadas nesse capítulo, ргоcuramos discutir em que medida as Tecnologias da Informação e Comunicação, baseadas na mídia digital, podem ser empregadas na preservação do patrimônio cultural e contribuir рага a construção da memória coletiva.

Nosso ponto de partida para esse entendimento foi baseado nos comentários do pesquisador Ulpiano T. Bezerгa de Meneses e nos estudos presentes na obra Theorizing digital cultural heritage: a critical discurse, que chamam atenção para três fatores que seriam fundamentais рага o estabelecimento da relação entre patrimônio/memória e tecnologias informacionais. Seriam eles: a comunicação, a virtualização e os sistemas.

No refere-se à comunicação, isto é, ao modo de acessar o conteúdo referente ao patrimônio cultural/memória com o emprego da mídia digital, apoiando-se principalmente nos trabalhos de Flusser, аргеsentamos a história dos conceitos sobre a comunicação, e discutimos, baseando-se em idéias de McLuhan, se a emergência das tecnologias informacionais não †eriam o poder de restabelecer diálogos mais próximos, agora em escala global, que haviam se perdido com o advento da mídia impressa, segundo Flusser. Além disso, também procuramos discutir a questão do acesso às tecnologias informacionais, que refere-se à garantia acesso às informações disponibilizadas nos ambientes virtual/híbrido. Nesse ponto definimos a inclusão digital, e expomos alguns exemplos ligados à preservação de bens culturais que ilustram essa prática. 
Sobre a virtualização - o modo de converter o conteúdo referente ao patrimônio cultural/memória com o emprego da mídia digital -, ргоcuramos entender a ргópria finalidade e os ganhos da tradução de um bem cultural ao ambiente virtual. Refletindo sobre conceitos fundamentais relativos ao patrimônio cultural, como autenticidade, cópia, original, entre outros, e também baseando-se em discussões de autores como Fiona Саmeron e Lev Manovich, entendemos que o virtual não seria um simulacro, mas outra forma de realidade, o que possibilitaria, рог meios distintos das tradicionais formas de preservação, a potencialização da compreensão sobre o patrimônio.

E, рог final, a respeito dos sistemas, isto é, sobre o modo de organizar a informação referente ao patrimônio cultural/memória com o emprego da mídia digital, nos apoiamos na Teoria Cibernética, especificamente em um de seus princípios básicos, segundo Bateson, de que o mapa não é o território. Vimos que uma possível forma de afastar perigos da multiplicação de gigantescas bases de dados, que muitas vezes apenas duplicam o concreto no virtual e não contribuem рага um maior aprendizado do patrimônio cultural, seria organizar informações no ambiente virtual como em um mapa. Isso quer dizer que, para que haja um ganho efetivo na virtualização de bem cultural, esta deve ser orientada a partir de uma seleção no território (ambiente concreto) de informações sobre um específico bem cultural que irá ser codificada no mapa (sistema/ambiente virtual). Utilizando-se das potencialidades das Tecnologias da Informação e Comunicação cria-se, com a interação do usuário no ambiente virtual, novas informações do bem concreto, que ampliaram seu entendimento - осогге uma retroalimentação informativa onde gera-se conhecimento.

Dessa forma, realizadas a discussão e compreensão desses três fatores, apresentaremos no capítulo 3 dessa dissertação o curso de extensão universitária PinhalDigital - Processos multimídia nas Fazendas de Café: história, arquitetura e tecnologia, uma experiência trans e interdisciplinar que procura tecer tais relações. Os entendimentos que tivemos no presente capítulo serão aplicados como critérios de análise desse curso. 


\section{capítulo 3}

ANÁLISE: curso de extensão PinhalDigital 
"Ali tinha uma palmeira que veio da África, então foi plantada, quando a fazenda aqui fez cem anos, um centenário, então a palmeira deu flor, ficou dessa grossura assim, mas ela não cresce alto demais, mais ou menos metade da altura dessa aí, ela deu flor uma penca de flor, de fora a fora assim e veio gente de Portugal tudo aí."

'Seo' José, velho jardineiro da Fazenda Pinhal, 2005.

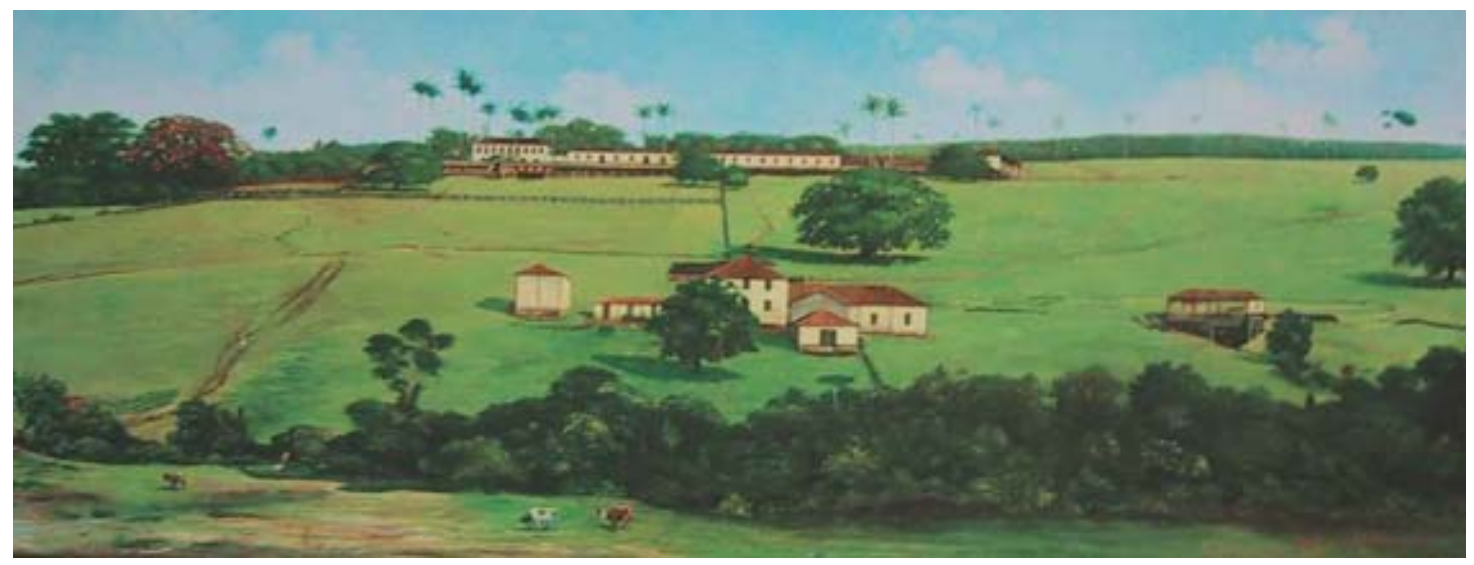

Fig.3.1: A Fazenda Pinhal, retratada por Benedito Calixto de Jesus, em 1900. 0 conjunto rural é o objeto de estudo do curso de extensão universitária Pinhal Digital.

No final do século XVIII, a região central do estado de São Paulo começou a ser povoada após a abertura de uma trilha que levava às minas de ouro de Cuiabá e Goiás [BENINCASA, 1998]. Saindo de Рiгacicaba, passando рог Rio Claro, subindo as escarpas das encostas do planalto, passando pelos campos, matas e cerгados de Агагаquara, levas de povoadores começaram a se estabelecer na região.

Em 1781, o sargento-mor de Itu, Cap. Carlos Bartholomeu de Агruda, comprou três léguas de terra na região, que haviam sido concedidas ao cirurgião-mor do Regimento de Voluntários Reais de São Paulo pela Coroa portuguesa. Tais †еггas só seriam demarcadas em 1831, dando origem à Sesmaria do Pinhal, que, juntamente com a demarcação das Sesmarias do Monjolinho e do Quilombo e a organização de propriedades rurais impulsionadas pela cultura do café, levariam à nucleação da atividade econômica na região, dando origem à cidade de São Carlos, na época fundada como São Carlos do Pinhal, em 1857. 
A mais importante das fazendas surgidas nessa região, indicada como a "célulamater" fundamental a partir da qual São Carlos cresceu e se desenvolveu [GORDINHO, 1985], foi a Fazenda Pinhal. Sua sede começou a ser construída em 1831 рог Сarlos José Botelho, filho do Cap. Carlos Bartholomeu de Агruda, com o objetivo de assegurar a definitiva posse daquelas tеггas. Nessa época, a cultura predominante na propriedade †ornou-se a cana-de-açúcar, cultivada por mão-de-obra escrava [FERRAZ, 1985]. Em 1853, a cana começou a ceder lugar à cultura cafeeira e a fazenda passou às mãos de

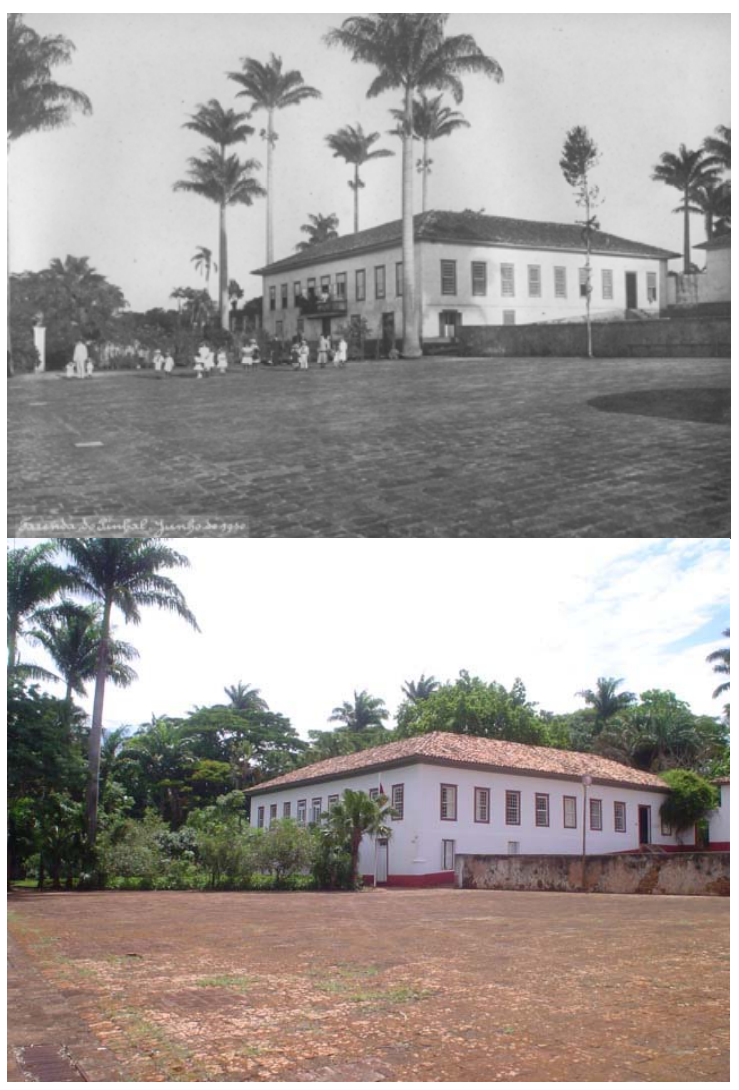

Fig.3.2: A Fazenda Pinhal em dois momentos: em junho de 1910 e em novembro de 2005, retratada durante as atividades da tегсеira edição do curso PinhalDigital.
Antônio Carlos de Аrruda Botelho o Conde do Pinhal -, filho de José Botelho. 0 Conde ampliou a sede da propriedade e reformulou seu agenciamento inicial, acrescentando ao conjunto гuгal tеггеiгоs, tulha e equipamentos indispensáveis a uma fazenda de café. À mão-de-obra escrava, alforriada pelo Conde em 1887, um ano antes da Abolição da Escravatura, gradualmente somaramse a mão-de-obra imigrante e colonos brasileiros. Assim, Antônio Carlos transformou a Fazenda Pinhal em uma das mais importantes produtoras de café do estado de São Paulo, o que the rendeu, além de prosperidade econômica, um grande prestígio político, que foi essencial nas negociações que ргорiciaram a vinda da estrada de ferгo à região.

0 Conde do Pinhal casou-se duas vezes. Sua segunda esposa, Anna Carolina de Mello Oliveira, a Condessa do Pinhal, com quem uniu-se em matrimônio após ficar viúvo em 1862, †ornaria-se a figura fundamental na conservação da fazenda após sua morte, em 1901. Bastante apegada ao lugar que ajudou a construir com o marido [GORDINHO, 1985], a Condessa transformaria a Fazenda Pinhal em um local especial de reuniões da 


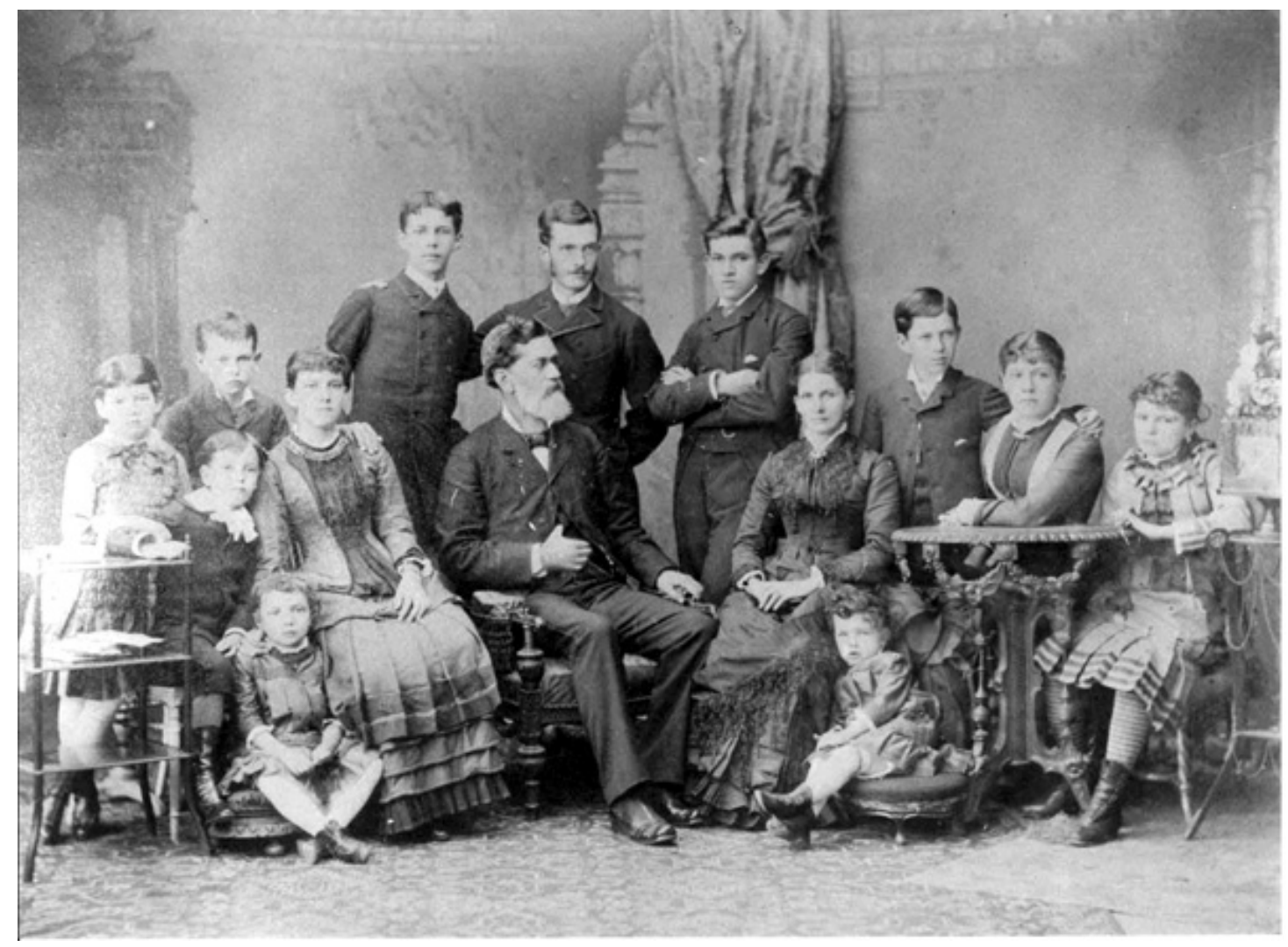

Fig.3.3: 0 Conde e a Condessa do Pinhal e filhos em foto da década de 1880

família Агruda Botelho, com seus jardins e bosques, onde recebeu рага †еmporadas seus filhos, netos e bisnetos, até o fim de sua vida, em 1945, aos 104 anos.

Mesmo após a morte da Condessa, a fazenda continuou a ter um significado especial рага a família Arruda Botelho. Em testamento, a matriarca recomendou que os herdeiros fizessem o possível para não vender as partes da propriedade a estranhos, mas sim a outros herdeiros. Рor isso, durante vinte e três anos, as terras регmaneceram indivisíveis. Após esse período, netos e bisnetos começaram a revezarse no zelo de manter a propriedade. 
Atualmente, a Fazenda Pinhal tem como principais proprietários Helena Vieitas Carvalhosa, uma das bisnetas da Condessa, e Modesto Carvalhosa. Рог se tratar de um dos poucos exemplares remanescentes da агquitetura colonial da região central do estado de São Paulo, o conjunto rural foi tombado em 1981 pelo CONDEPHAAT -

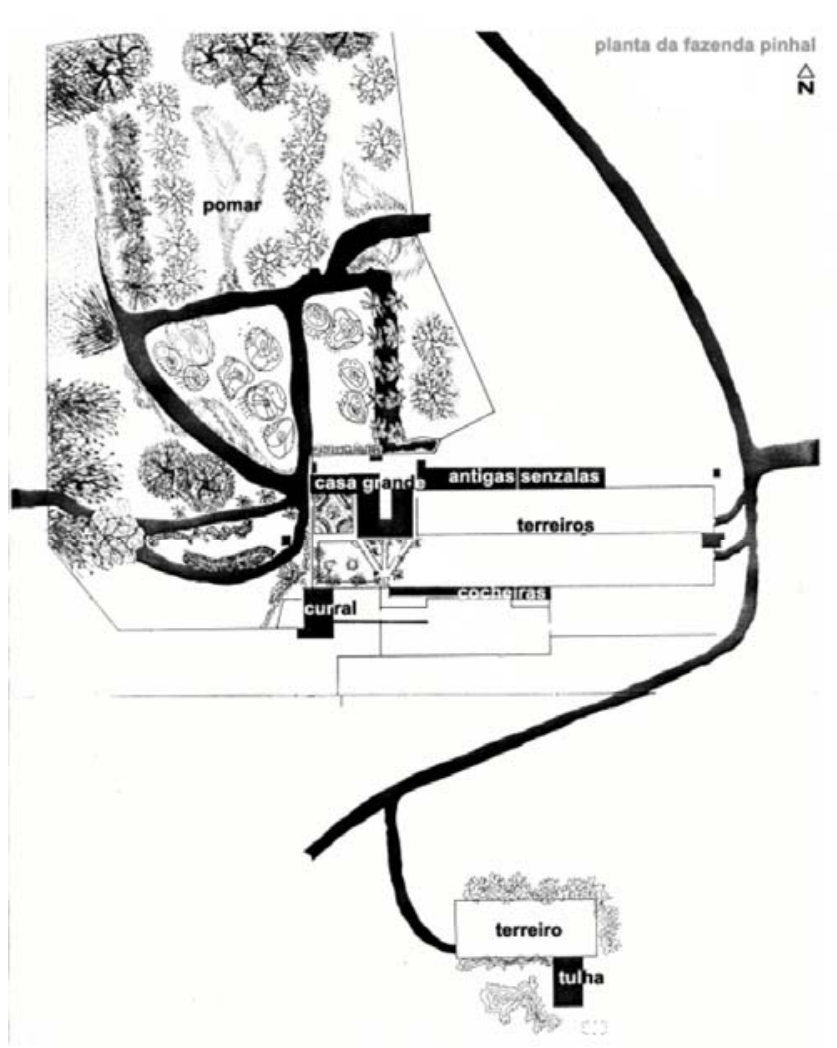

Fig.3.4: Planta de situação da Fazenda Pinhal.
Conselho de Defesa do

Patrimônio Histórico,

Arqueológico, Artístico e

Turístico, e em 1987 pelo IPHAN

- Instituto do Patrimônio

Histórico e Artístico Nacional.

Com o declínio da produção

cafeeira, outros meios de

captação de recursos para a

conservação do lugar tiveram

que ser pensados. Assim, no ano

de 1990, com a finalidade de dar

apoio à manutenção desse patrimônio cultural, foi criada a Associação Pró Casa do Pinhal, com o objetivo de incentivar e

desenvolver atividades de ensino, pesquisa e extensão no conjunto rural. Um dos exemplos da atuação da associação foi, por exemplo, a promoção do Seminário Garantindo a Presença da Memória, um importante encontro de centros de memória e universidades bгasileiras, do qual participamos em 2006. Além disso, a partir de 1991, a Fazenda Pinhal tornou-se um centro de turismo cultural, com a conversão de parte de seus prédios, como a antiga senzala, em um hotel rural, com restaurante e áreas de lazer, que tem recebido diversos hóspedes e visitantes desde então.

\subsection{PinhalDigital - de workshop a curso de extensão: difusão}

Realizou-se na Fazenda Pinhal, esse importante patrimônio ligado à memória da cidade de São Carlos, entre os anos de 2003 e 2006 um curso de extensão e difusão 
universitária denominado PinhalDigital - Processos multimídia nas Fazendas de Café: história, arquitetura e tecnologia. Esse tratou-se de uma experiência que teve como um dos objetivos "†ransformar a Fazenda Pinhal num centro vivo e dinâmico de memória, capaz de permitir a exploração de todo o potencial dos acervos lá existentes" [PRATSCHKE; BORTOLUCCI; SIGOLI, 2005, p.2].

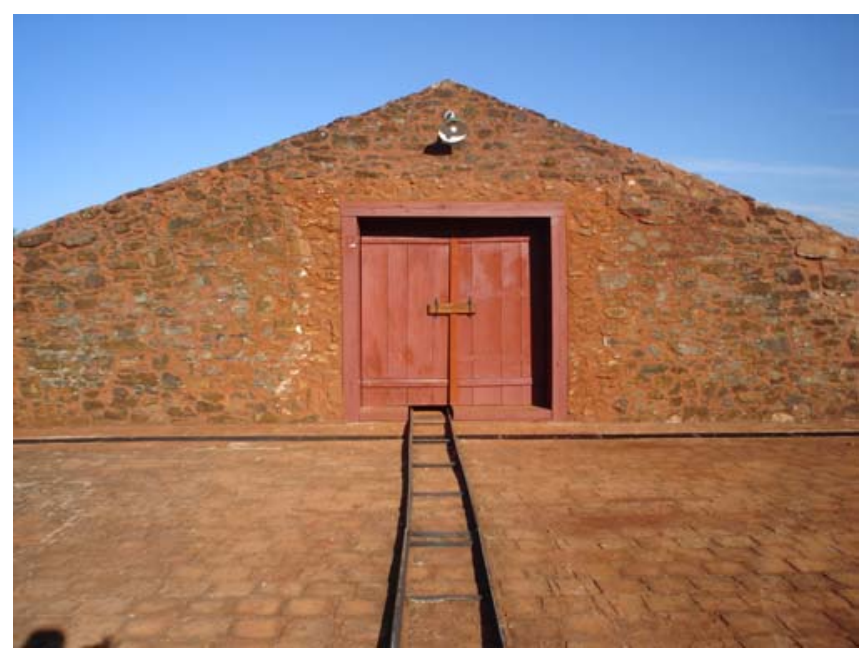

Fig.3.5: Vista frontal da Tulha, edifício do conjunto rural que serviu de motivação para a realização do curso PinhalDigital.
A motivação original рага a realização do curso nasceu de uma visita do renomado mídia artista australiano Jeffrey Shaw ${ }^{51}$ à Fazenda Pinhal, em junho de 2003, através de um convite feito pela Рrofa. Dга. Anja Pratschke, do Departamento de Arquitetura e Urbanismo da Escola de Engenharia de

São Carlos, Universidade de São Paulo (SAP-EESC-USP). Na ocasião, a ргоргietária Sгa. Helena Carvalhosa, em presença da Profa. Anja Pratschke, desde a época responsável pelo laboratório informatizado do SAP-EESC-USP, e do artista Jeffrey Shaw, ехргеssou, ao visitar a Tulha ${ }^{52}$ abandonada da fazenda, sua vontade de ter disponível um ambiente virtual tridimensional para mostrar o funcionamento das máquinas de beneficiamento de café da época de produção, que pudesse ser visualizada a partir de uma interface computacional [PRATSCHKE; BORTOLUCCI; SIGOLI, 2005]. Este foi o ponto de partida que desencadeou um movimento em direção a realização desse desafio, no entanto, de forma ampliada, baseando-se em um levantamento e leitura analítica do objeto de estudo - a Tulha -, em seus múltiplos aspectos: histórico, econômico, geográfico, arquitetônico e de modos de vida, рага citar alguns.

Рага a viabilização dessa experiência, contou-se então com o envolvimento de um conjunto de pesquisadores (рог volta de 120, entre 2003 e 2006), compostos por

\footnotetext{
${ }^{51}$ Trabalhos e textos do artista disponiveis em: <http://www.jeffrey-shaw.net/>.

${ }^{52}$ A Tulha consiste em uma espécie de armazém onde o café егa beneficiado e estocado.
} 
alunos de graduação, pós-graduação e professores, inicialmente pertencentes apenas à comunidade acadêmica da cidade de São Carlos, геpresentada por duas grandes universidades públicas - a Universidade de São Paulo (USP), campus de São Carlos, e a Universidade Federal de São Carlos (UFSCаг). Em 2006, pesquisadores da UNESP, campus de Агагаquara, também integraram-se aos trabahos. Além disso, foi também fundamental para a realização desse curso o apoio da Associação Pró Casa do Pinhal, que possibilitou uma ampla abertura da fazenda aos pesquisadores envolvidos, que, contando com toda infra-estrutura do local, como funcionários à disposição e refeições diárias, assim como o acesso a todos os espaços e acervos do conjunto rural, iniciaram a série de levantamentos in loco dos bens culturais ali presentes.

O registro do rico acervo do conjunto rural baseou-se em um processo de construção "inter" e "†ransdisciplinar" de conhecimento, que permitiria múltiplos olhares sobre um mesmo objeto, enriquecendo o entendimento sobre o patrimônio ali existente [PRATSCHKE, 2004]. Nesse ponto vale uma distinção entre os conceitos de multidisciplinaridade, interdisciplinaridade e transdisciplinaridade na construção desses saberes. Segundo Gondar [2005, p.14-15],

Nos procedimentos multidisciplinares, um somatório de disciplinas é requerido рага dar conta de um mesmo objeto teórico sem que haja necessidade de um entrecruzamento das diferentes abordagens, podendo cada disciplina manter-se em sua própria esfera. Afirma-se polissemia discursiva, mas a ordem disciplinar se mantém. Na interdisciplinaridade, tem-se igualmente um mesmo tema sendo trabalhado por disciplinas distintas, porém os discursos acerca desse tema são postos em diálogo. A idéia central é a de que o universo dos saberes deve ser democrático: busca-se o diálogo, admite-se a paridade dos participantes e procura-se dar ao debate o horizonte do consenso. Evidentemente, o leque se abre, mas a divisão disciplinar permanece, ainda que cada disciplina seja capaz de ouvir o que a outra tem a dizer (...) A proposta transdisciplinar é outra. Ela pretende por em xeque a distinção entre as disciplinas, valorizando pesquisas capazes de atravessar os domínios separados. A idéia não é reunir conteúdos, mas produzir efeitos de transversalidade entre os diversos saberes. Transversalidade que, evidentemente, não toma a síntese por horizonte: não se trata de promover o diálogo entre disciplinas em prol de um consenso, de um equilíbrio último em que a razão domine o caos. Ao contrário, supõe-se que é justamente do dissentimento que se faz a invenção e podem ser geradas as novas idéias. 0 objeto transdisciplinar não é comum a diferentes disciplinas; ele é criado como um novo objeto, de maneira transversal, quando problemas que até então eram рróprios de um campo de saber atravessam seus limites e fecundam outros. Esse objeto não existe antes que o atravessamento se dê. 
As atividades do PinhalDigital foram coordenadas pela Profa. Dга. Anja Pratschke, do SAP-EESC-USP, responsável pela organização dos sistemas computacionais e pela integração dos participantes de forma transdisciplinar; pela Рrofa. Dra. Maria Ângela Регеira de Castro e Silva Bortolucci, do SAP-EESC-USP, responsável pela organização dos levantamentos referentes à história da arquitetura do conjunto rural; e pela Profa. MSc. Luzia Sigoli Fernandes Costa, do curso de Ciência da Informação da UFSCar, responsável pela organização dos documentos históricos presentes na fazenda.

Os pesquisadores participantes agruparam-se em cinco áreas de interesse: na área da história, voltando-se рага a pesquisa bibliográfica e documental, levantamento огаl, рог meio de entrevista com pessoas que viveram na fazenda, inspeção cuidadosa dos edifícios, mobiliário e objetos рага fazer os devidos reconhecimentos, como o entendimento dos modos de vida, as técnicas construtivas e a preservação do patrimônio; na área de linguagem em arquitetura ocupando-se dos levantamentos métricos, dos desenhos de observação, dos desenhos técnicos; na área de artes e comunicação voltando-se para os levantamentos e registros fotográficos, filmagens e capłação de mensagem sonora; na área da ciência da informação utilizando-se dos геcursos da linguagem documental рага sistematizar, огganizar e dar acesso aos conhecimentos агmazenados; е рог final aqueles na área de computação, pautando-se em conceber sistemas multimídia, usando, como por exemplo, o desenho auxiliado por computador (CAD) e de modelação tridimensional, para efeito de animações, dentre outros recursos. 
Em todas suas edições, o curso foi dividido em duas fases: primeiramente na Fazenda Pinhal, com carga horária de 44 horas, momento em que se dariam os levantamentos e registros dos bens culturais do conjunto rural; e depois em laboratório na Escola de Engenharia de São Carlos - USP, com carga horária de mais 20 horas, momento de organização final das informações coletadas em in loco. Os levantamentos, a partir de 2004, contaram a utilização de um software específico, denominado i-class, desenvolvido pelo Instituto de Ciências Matemáticas e de Computação da USP (ICMC-USP), que permitiu o registro e o depósito de tudo que егa levantado durante a estadia na fazenda. Рara dar suporte ao trabalho, criou-se um

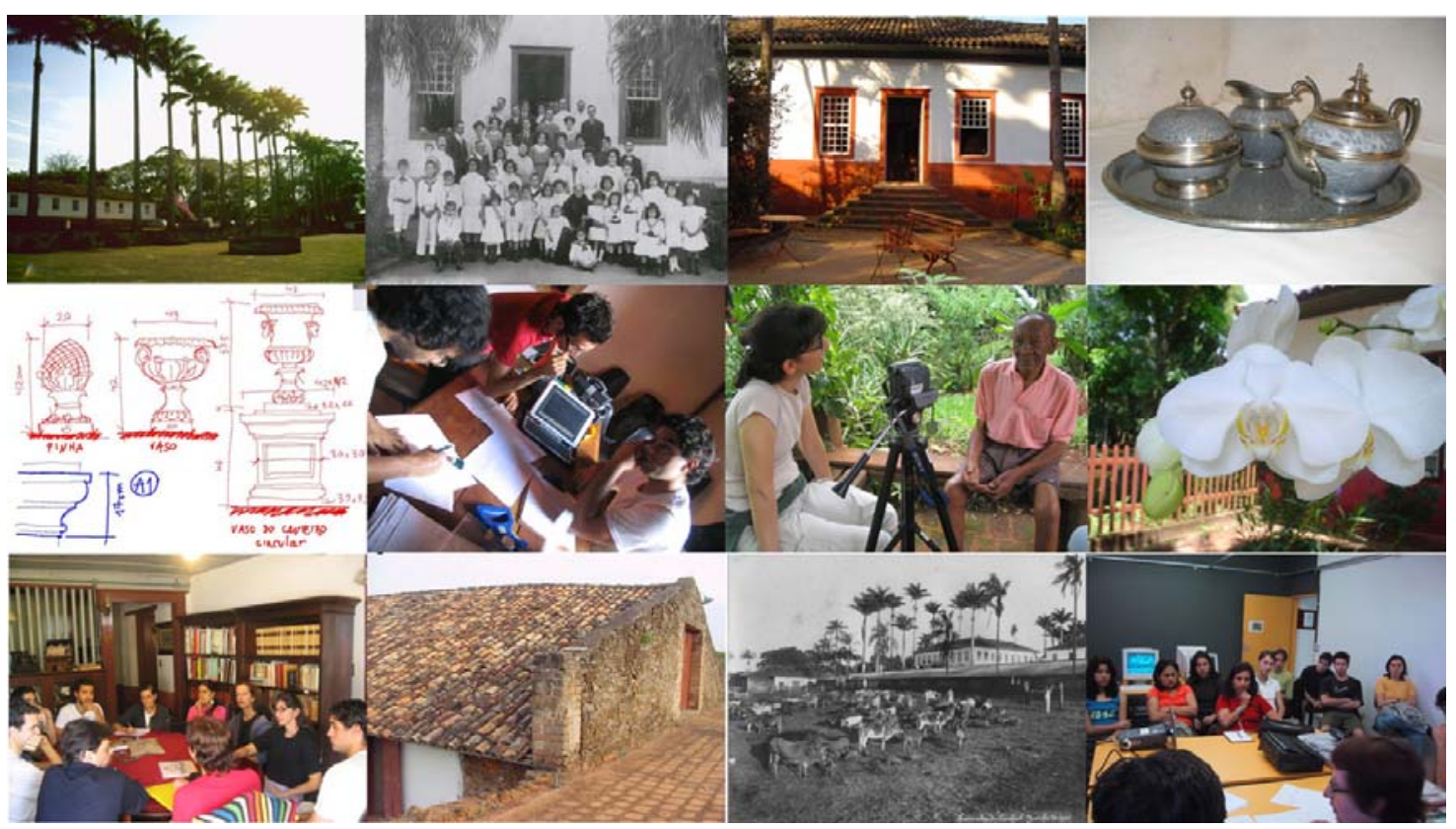

Fig.3.6: As atividades realizadas ao longo de todas as edições do curso PinhalDigital: registros fotográficos e em vídeos dos prédios, do patrimônio natural, de objetos e personagens da Fazenda Pinhal; recuperação de antigas fotos; registro das reuniões dos grupos trabalho e de seus levantamentos.

espaço computacional com um servidor e rede sem fio na biblioteca da Casa Grande, que permitiu conectar-se com Tablet-PCs lespécie de computador compacto e móvel que permite anotações em sua própria tela) na distância de 150m para classificar e organizar os conteúdos registrados em tempo real.

Os esforços na primeira edição do PinhalDigital concentraram-se no estudo da Tulha, expandindo-se para a pesquisa sobre o funcionamento das máquinas de separação de grãos, assim como para o próprio percurso do café antes de chegar no 
local, e daí até os limites da fazenda [PRATSCHKE, 2004]. Ressaltamos que essa ргіmeira edição, ocorrida em 2003, foi realizada ainda no formato de workshop. Participaram na ocasião 38 pesquisadores, sendo eles: 20 alunos da USP São Carlos, com 12 graduandos do Departamento de Arquitetura e Urbanismo, 7 pós-graduandos também do Departamento de Arquitetura e Urbanismo e um aluno de pós-graduação da Computação; 7 alunos da UFSCar, com dois graduandos do curso de Imagem e Som e três do curso de Ciência da Informação; 4 pesquisadores externos, sendo dois arquitetos formados pelo Departamento de Arquitetura e Urbanismo da USP e dois graduandos do curso de Ciências Sociais da UNESP de Агагаquara; 6 ргоfessores, 4 do Departamento de Arquitetura e Urbanismo da USP, um da Computação da USP e um do curso de Ciência da Informação da UFSCar; e um técnico do Departamento de Arquitetura e Urbanismo da USP, conforme a documentação que tivemos acesso ${ }^{53}$. Como nos relatou Pratschke [2007] em entrevista, essa foi a única edição do PinhalDigital em que não se trabalhou na fazenda diretamente com os TABLET-PCs e a rede sem fio. Todo o trabalho de digitalização das informações colhidas acabou ocorrendo posteriormente em laboratório.

Já em sua segunda edição, realizada em 2004, a experiência tomou a forma de um curso de extensão e difusão universitária. Desse modo, o PinhalDigital transformouse em uma atividade reconhecida pela Pró-Reitoria de Cultura e Extensão Universitária da USP, que possibilitou a oficialização da abertura à participação de qualquer pessoa, ligada à universidade ou não, com direito a certificado após o curso. Sublinhamos que esse formato institucionalizou o PinhalDigital como uma reunião de uma "constelação" de participantes, formada рог especialistas e estudantes de diversas áreas do conhecimento, algo importantíssimo devido à ргópria ргоposta de se ргорогcionar uma experiência caracterizada por "múltiplos olhares sobre um patrimônio cultural" [PRATSCHKE, BORTOLUCCI, SIGOLI, 2005, p.1].

0 foco dos trabalhos em 2004 foi outra edificação do conjunto rural - a Casa Grande, ou a Casa de Morada, e todos os bens culturais materiais e imateriais a ela associados. Os levantamentos partiram das áreas de serviço da casa, como a cozinha, o

\footnotetext{
${ }^{53}$ Disponível no Laboratório de Ensino de Informática do Departamento de Arquitetura e Urbanismo da USP São Carlos.
} 
quarto onde se guardavam as carnes e o quarto dos biscoitos, dentre outros compartimentos, sendo direcionados ao desvendamento do cotidiano das famílias e dos trabalhadores que lá viveram desde as primeiras décadas do século XIX. Foi nessa edição que empregou-se, pela primeira vez, as Tecnologias de Informação e Comunicação, utilizando-se TABLET-PCs e rede sem fio no registro in loco do acervo da fazenda. Além disso, ргоcurou-se organizar todo o conteúdo com a utilização do software iclass, um protótipo de um sistema de classificação de bens culturais que esta sendo atualmente utilizado em um projeto de políticas públicas que envolve a catalogação de todo patrimônio cultural da cidade de São Carlos e região, denominado Memória Virtual de São Carlos, no qual tivemos uma participação como pesquisador, sob orientação da Ргоfa. Dга. Anja Ргatschke, no subgrupo Paradigmas de Interface, em 2006.

Estiveram presentes, no PinhalDigital 2, 40 pesquisadores, sendo eles: 24 alunos da USP São Carlos, com 13 graduandos do Departamento de Arquitetura e Urbanismo, três pós-graduandos também do Departamento de Arquitetura e Urbanismo, 4 graduandos da Computação e 4 pós-graduandos também da Computação; 9 alunos da UFSCar, com 4 graduandos do curso de Imagem e Som e 5 graduandos do curso de Ciência da Informação; 5 professores, dois do Departamento de Arquitetura e Urbanismo da USP, um da Computação da USP, um do curso de Imagem e Som da UFSCar e um do curso de Ciência da Informação também da UFSCar; e dois técnicos do Departamento de Arquitetura e Urbanismo da USP.

Um ano depois, em 2005, осоггеu o PinhalDigital 3, em que participamos como inscrito pela primeira vez. Naquela edição, dado o grande volume de informações acumuladas durante as duas edições anteriores, decidiu-se não eleger um objeto central que nortearia os levantamentos. Optou-se, naquele momento, pela organização e complementação do material já produzido [PRATSCHKE; BORTOLUCCI; SIGOLI, 2005]. Рага atingir esse objetivo, formou-se durante o PinhalDigital 3 quatro grupos de trabalho divididos em ateliês. Conforme as coordenadoras do curso, o primeiro desses ateliês denominou-se Café: história e processo produtivo, onde realizou-se uma leitura de fotografias panorâmicas tridimensionais, produzindo-se a partir dessas imagens narrativas e legendas que possibilitaram dar sentido ao seqüenciamento das fotos, 
levantamento complementar, principalmente da Tulha. Além disso, organizou-se informações já levantadas, produziu-se novas e reviu-se textos informativos sobre o processo produtivo do café.

O segundo ateliê chamou-se PinhalMundo: interface com o Memória Virtual, do qual participamos na figura de sub-coordenador. Suas atividades foram voltadas рага a elaboração de uma proposta de interface da Fazenda Pinhal com o Projeto de Políticas Públicas Memória Virtual de São Carlos, sendo que muitos dos dados levantados por essa atividade se prestaram a servir de insumos para testar o protótipo da base de dados deste Projeto [PRATSCHKE; BORTOLUCCI; SIGOLI, 2005].

0 tегсеiro ateliê denominou-se Site do PinhalDigital: interface para visualização da informações disponíveis. Sua proposta foi a realização de um website do curso PinhalDigital, visando facilitar o trabalho interdisciplinar dos pesquisadores diretamente envolvidos. Este website funcionaria como um repositório de todo o acervo digital gerado pelas atividades, facilitando, também, o acesso à produção acadêmica.

E рог final, o quarto ateliê chamou-se Paisagens: preâmbulo para o PinhalDigital 2006. Nele foi realizado o primeiro reconhecimento do paisagismo existe no entorno da Casa Grande (jardins, pomar e bosque), dando início às atividades do PinhalDigital do ano seguinte. Observamos que esse ateliê contou com a participação de uma professora paisagista, uma característica do curso PinhalDigital, que a cada edição procurou ampliar a participação de pesquisadores de diversas áreas do conhecimento.

Nessa †егсеіга edição do PinhalDigital, estiveram presentes 39 pesquisadores, sendo eles: 26 alunos da USP São Carlos, com 14 graduandos do Departamento de Arquitetura e Urbanismo, 8 pós-graduandos também do Departamento de Arquitetura e Urbanismo, 3 graduandos da Computação e um pós-graduando também da Computação; três alunos de graduação do curso de Ciência da Informação da UFSCar; 7 professores, 4 do Departamento de Arquitetura e Urbanismo da USP, um da Computação da USP, Um do curso de Imagem e Som da UFSCar e um do curso de Ciência da Informação também da UFSCar; dois técnicos do Departamento de Arquitetura e Urbanismo da USP; e uma artista plástica. 
A última edição do curso PinhalDigital ocorreu em 2006, tendo como tema os jardins, os pomares e as matas nas proximidades da sede da fazenda. Além de ampliar a participação de pesquisadores de outras áreas do conhecimento, como paisagistas e alunos da Engenharia Ambiental da USP São Carlos, nessa edição ampliou-se também a participação institucional no curso, com a presença de alunos e professores do curso de Letras da UNESP de Агагаquara. Esta foi a edição com o maior número de participantes entre todas.

No PinhalDigital 4 mais uma vez repetiu-se а organização interna dos trabalhos em quatro grupos temáticos, no entanto as equipes mudaram e metodologias foram revistas. 0 foco central passou a ser o processo em si de geração de conhecimentos a partir dos levantamentos dos bens culturais do conjunto rural. Estivemos mais uma vez presente, fazendo parte das atividades do primeiro desses grupos, denominado Produtos, sistema Internet e Edição, responsável pelo desenvolvimento de uma interface computacional onde se organizaria todo o conteúdo produzido nessa edição.

Já o segundo grupo em 2006 foi chamado de Documentários, sendo responsável pelo registro em sons e imagens dos personagens da fazenda e das atividades realizadas pelos participantes. Alguns dos produtos desse grupo foram o Making of das atividades, uma entrevista com o velho jardineiro da Fazenda, o Seo José, e um vídeo que ргоcura desvendar os caminhos, рог exemplo, das frutas do pomar da fazenda até chegarem à cozinha, рага serem transformadas em geléias e então serem vendidas aos visitantes.

0 terceiro grupo foi responsável pelo levantamento e identificação da paisagem. Foi o maior dos grupos, cujas atividades se subdividiram entre a identificação da bacia em que está localizada a fazenda e o caminho das águas em seu interior, assim como a classificação e identificação da vegetação e das frutas presentes no jardim e pomar.

0 último dos grupos do PinhalDigital 4 foi o denominado Memória, Textos, Desenhos, responsável pela produção de textos-narrativas para a Casa Grande, a Tulha e a Paisagem, além da transcrição de entrevistas dos personagens da Fazenda Pinhal. 
Рarticiparam dessas atividades da quarła edição do curso 56 pesquisadores, sendo eles: 28 alunos da USP São Carlos, com 18 graduandos do Departamento de Arquitetura e Urbanismo, 5 pós-graduandos também do Departamento de Аrquitetura e Urbanismo, um graduando da Computação, um pós-graduando também da Computação e três alunos da Engenharia Ambiental; 16 alunos da UFSCar, com 5 graduandos do curso de Imagem e Som, 9 graduandos do curso de Ciência da Informação, um graduando do curso de Ciências Sociais e um graduando do curso de Psicologia; três alunos do curso de Letras da UNESP de Агагаquara; 7 ргofessores, 4 do Departamento de Arquitetura e Urbanismo da USP, um da Computação da USP, um do curso de Ciência da Informação da UFSCar e um do curso de Letras da UNESP; e dois técnicos do Departamento de Arquitetura e Urbanismo da USP.

\subsection{A comunicação no curso PinhalDigital}

Como vimos no capítulo anterior, a questão da comunicação na digitalização de bens culturais liga-se ao design dos ambientes virtuais ou híbridos onde as informações referentes ao patrimônio cultural serão disponibilizadas (relação usuário-interface computacional), e também à "cultura digital" ou "alfabetização digital" da população usuária desses ambientes (relação usuário-tecnologias informacionais).

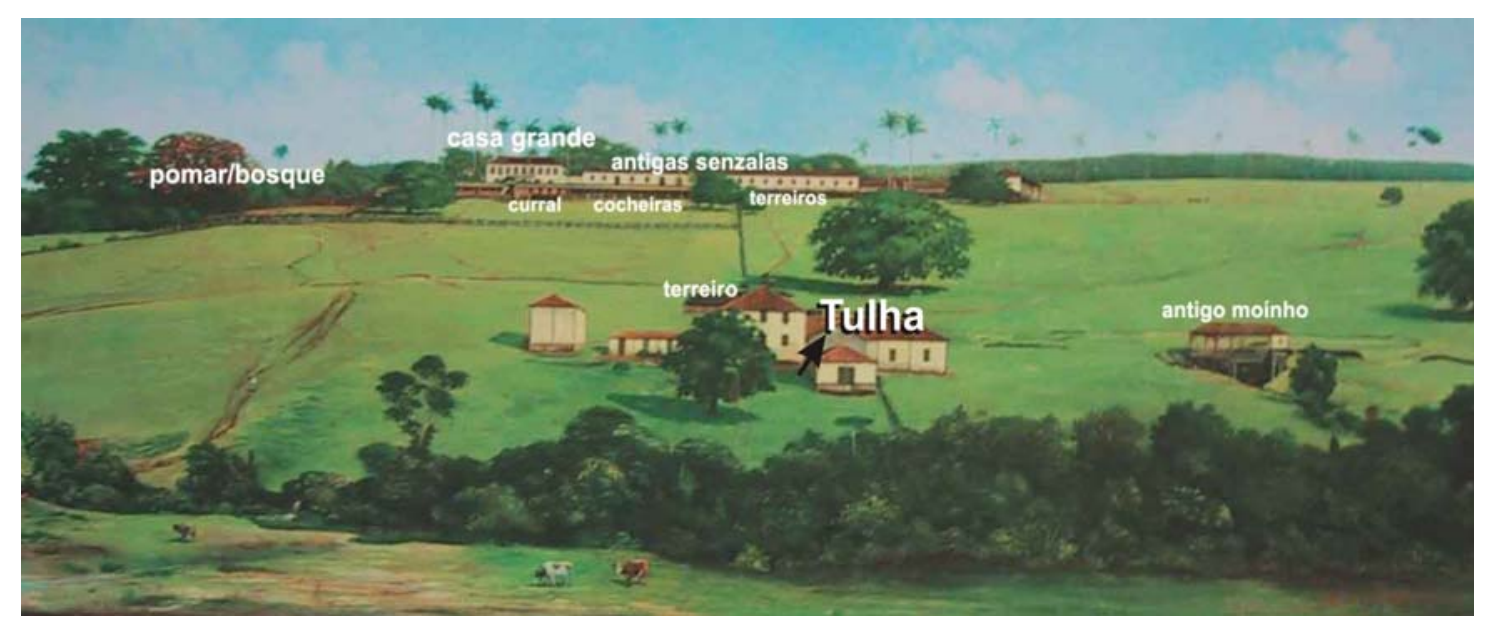

Fig.3.7: Proposta da interface computacional do PinhalDigital: acesso aos conteúdos a partir dos edifícios e demais espaços do conjunto rural retratados na pintura de Calixto. 
No curso PinhalDigital, o fator da comunicação relacionado à concepção da interface computacional, podendo ser entendida como o "арагаto material que permite a interação entre o universo da informação digital e o mundo ordinário" [LÉVY, 2003, p.37], que permitiria, no caso desse projeto, o acesso ao acervo digitalizado do conjunto rural, é baseado na Mnemônica ou Arte da Memória, muito difundida durante a tradição oral medieval, mas que entrou em declínio após o advento da imprensa e o modelo textual de memória [FENTRESS; WICKHAM, 1992]. Acreditando que as tecnologias informacionais possibilitariam a гесuperação de nossa capacidade de associar espaços a informações [PRATSCHKE, 2002], escolheu-se como "portal de entrada" ao universo virtual dos bens culturais da Fazenda Pinhal uma pintura digitalizada que retrata toda a ргоpriedade гural, pintada em 1900 pelo renomado artista Benedito Calixto de Jesus, que encontra-se originalmente exposta na Casa Grande ${ }^{54}$. As matas, os jardins, os cafezais, a senzala, a tulha, a Casa Grande, tudo está presente na obra. A interface funcionaria da seguinte forma: "cada prédio da pintura seria relacionado a diversos conteúdos, estruturados em volta de narrativas diversas, que por sua vez, reforçariam a ligação com as atividades que aconteceram junto a este prédio" [PRATSCHKE; BORTOLUCCI; SIGOLI, 2005, p.4].
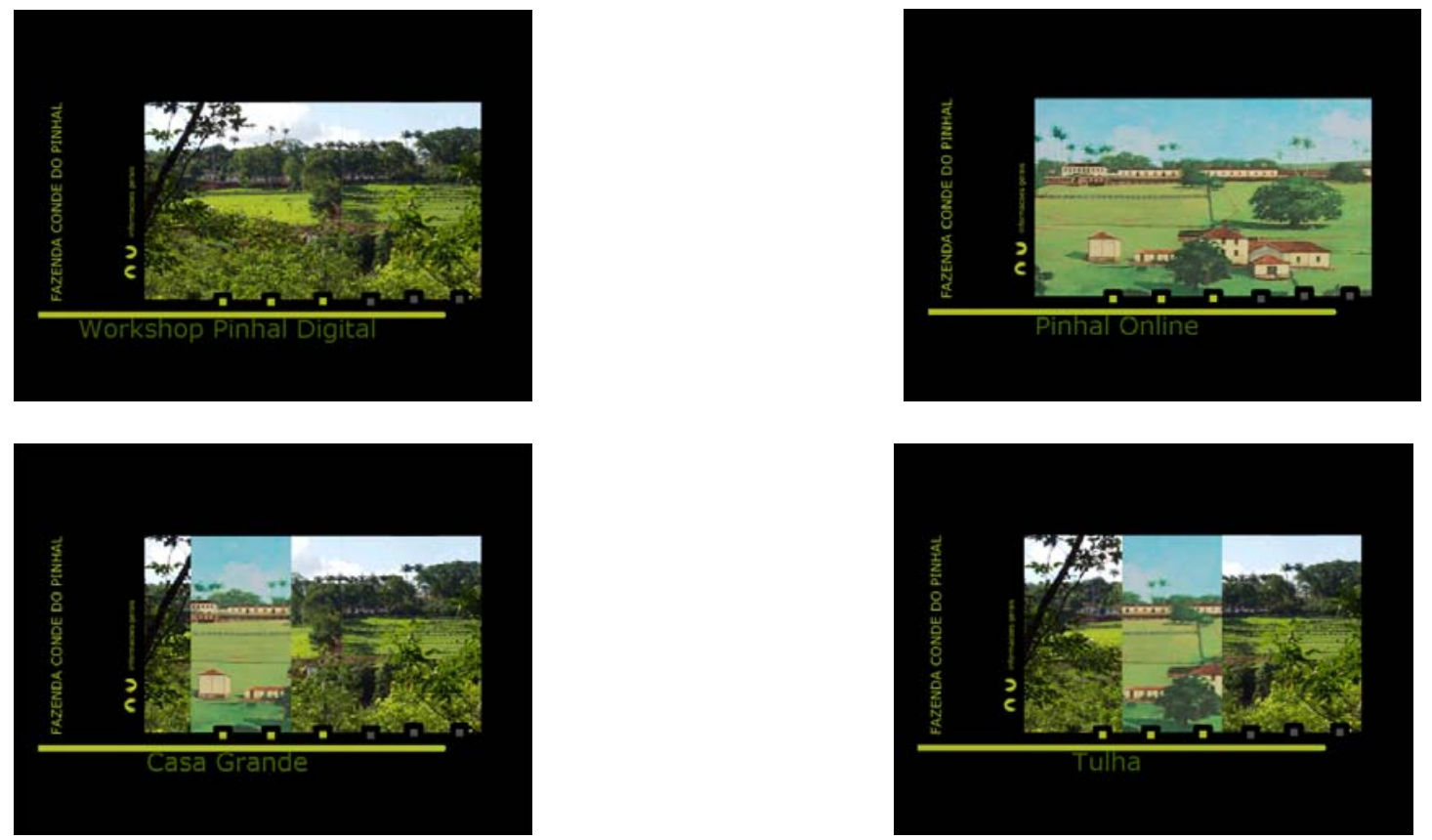

Fig. 3.8-3.11: Interface desenvolvida pelo grupo que sub-coordenamos durante o PinhalDigital 3. Tratou-se de uma reinterpretação da proposta original. Nela, a partir da sobreposição entre uma foto tirada por nossa equipe em 2005 e a pintura de Calixto, seria possível acessar conteúdos levantados em todas as edições do curso.

\footnotetext{
${ }^{54}$ Página inicial do PinhalDigital disponível em: <http://www.saplei.eesc.usp.br/pinhaldigital/>.
} 
0 processo de design dessa interface baseou-se em formas de trabalho colaborativo apoiado nas tecnologias informacionais. Segundo as coordenadoras do projeto, havia também o desejo de que o produto final desse processo, isto é, a interface computacional parcial desenvolvida ao final do curso, também permitisse que seus usuários se †ornassem produtores de seu conteúdo, algo que poderia ser alcançado se pensássemos em uma interface colaborativa. Sobre o fato, afirmou-se que o PinhalDigital

é uma experiência que envolve os dois lados do processo de design, o designer que esta criando os conteúdos e desenhando essa experiência digital e o usuário que esta interagindo e construindo conhecimento de forma individualizada. Esses dois lados, de preferência, podem e devem se cruzar e trocar de papel [PRATSCHKE; BORTOLUCCI; SIGOLI, 2005, p.01].

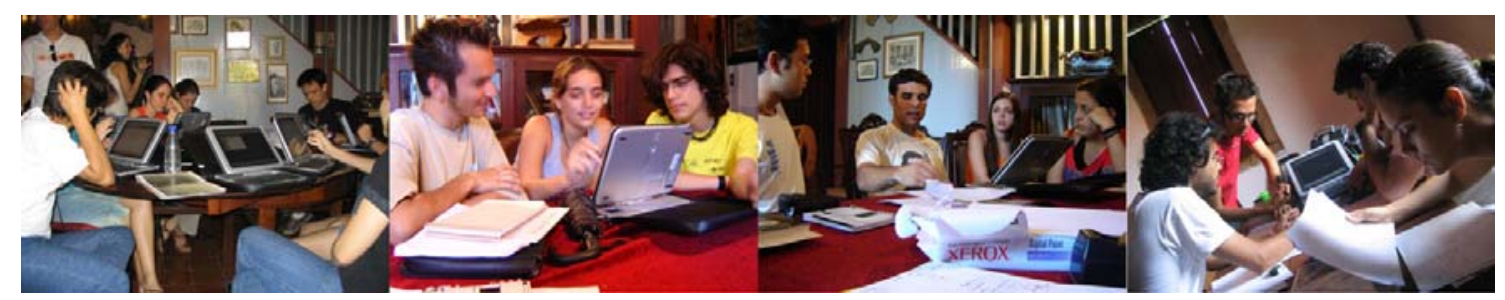

Fig.3.12 Trabalho colaborativo entre os pesquisadores durante as atividades do PinhalDigital.

Relembramos que uma interface colaborativa é um ambiente virtual que permite a comunicação interpessoal entre múltiplos usuários, através da postagem de mensagens, imagens, vídeo ou áudio. Desse modo, ao usuário pode ser dado também o papel de ргodutor de conteúdos. Temos, dessa forma, a chamada reconfiguração de práticas na comunicação [LÉVY, 2001]. Sendo a interface do PinhalDigital colaborativa, permitindo uma produção de conteúdos e comunicação em mão-dupla, pode-se pensar, рог exemplo, na possibilidade dos visitantes da fazenda registrarem, com câmeras digitais, os espaços ou lugares mais interessantes do conjunto rural em sua opinião, tecendo comentários sobre essa escolha. Os registros e comentários poderiam ser então disponibilizados na interface do projeto, fazendo com que, através de diversos olhares - justamente uma das questões centrais do projeto -, mais conteúdo fosse gerado sobre os bens culturais ali presentes. 


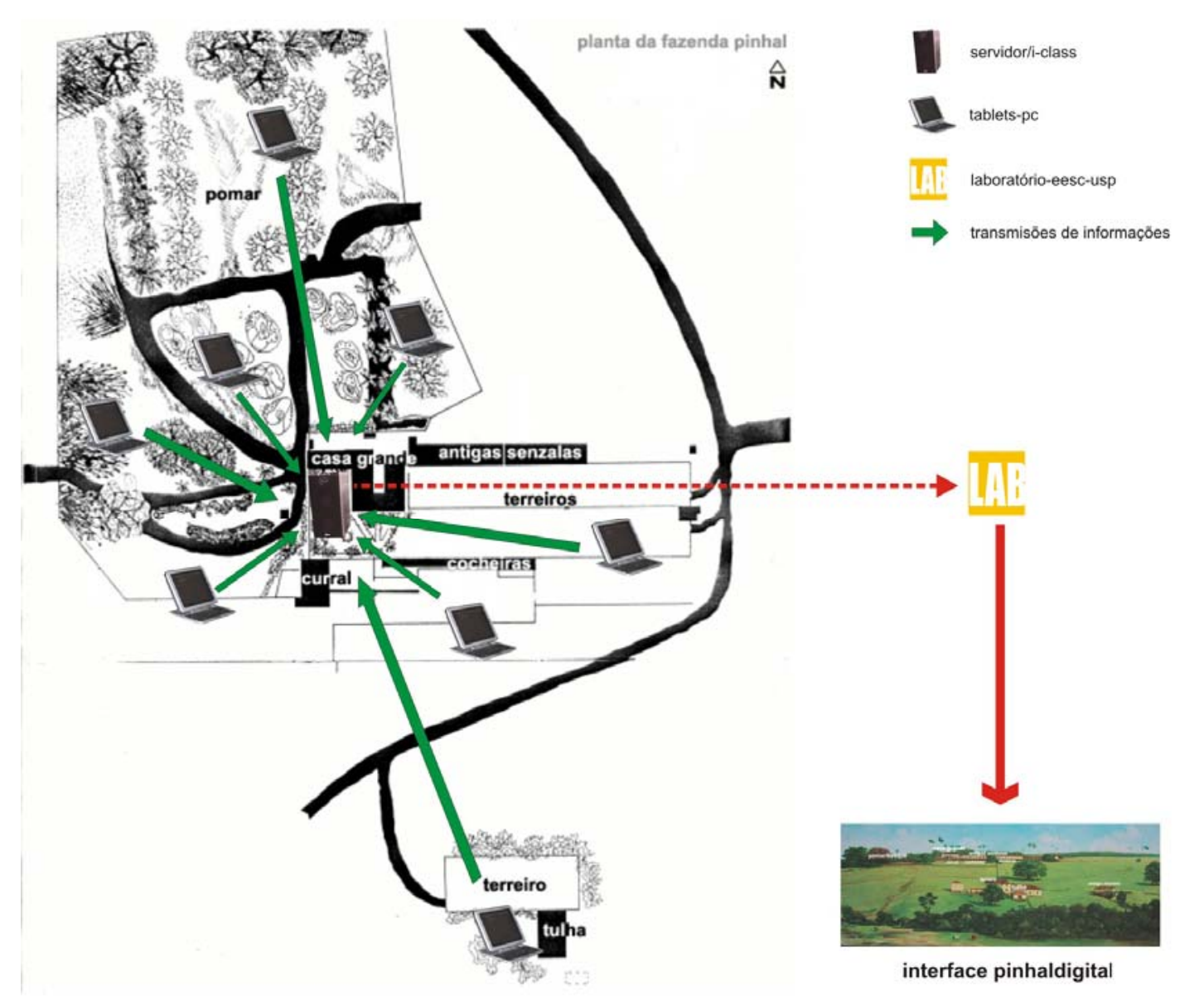

Fig.3.13: Esquema sobre o processo colaborativo de design da interface computacional do PinhalDigital. As informações sobre os bens culturais da Fazenda Pinhal são levantadas em colaboração e transferidas para o servidor localizado na biblioteca da Casa Grande. Depois do trabalho in loco, as informações são organizadas em laboratório da EESCUSP, visando a produção da interface computacional.

0 produto final do PinhalDigital como uma interface colaborativa, também seria de grande importância se refletíssemos sobre o fator da comunicação ligada às relações de alfabetização dos usuários frente às tecnologias informacionais. Acreditamos, assim como ocorreu no Plano de Alfabetização Digital de Extremadura, que a гесuperação da memória local рог meio da divulgação do patrimônio cultural pode servir como uma poderosa aliada para a inclusão digital da população ligada a esse patrimônio. 0 uso de tecnologias colaborativas poderia potencializar ainda mais essa ação, envolvendo mais essa população, não simplesmente como usuária, mas ativamente como ргodutora de novos conteúdos dos bens culturais em questão. 


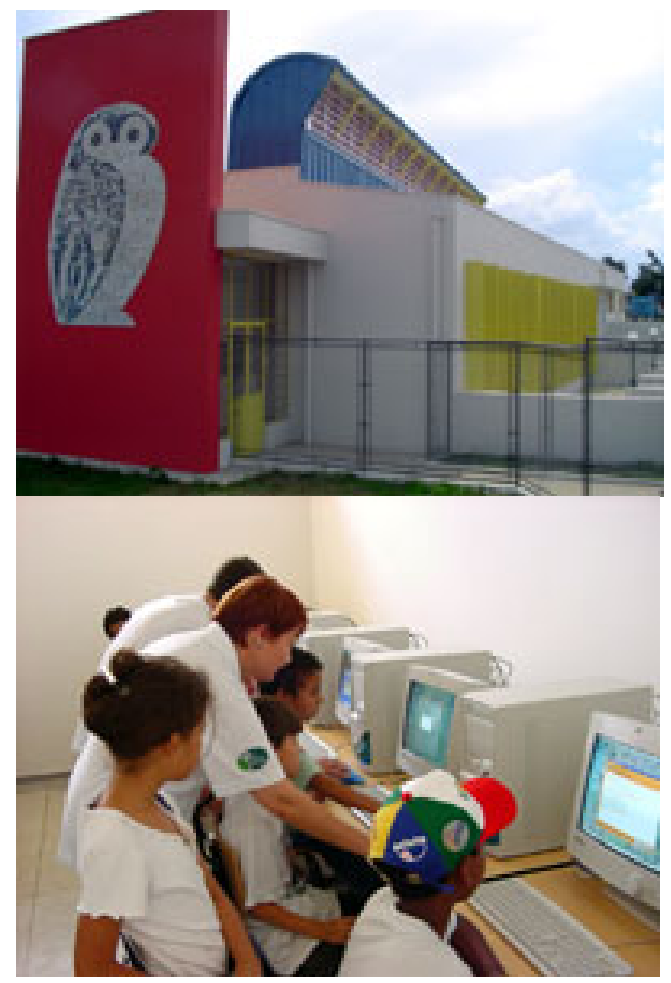

Fig.3.14: A chamada "Escola do Futuro", que funciona como um telecentro do programa de inclusão digital da Prefeitura Municipal de São Carlos. Sua articulação com o projeto PinhalDigital
Pensando sobre uma estratégia de inclusão digital nesses moldes e envolvendo 0 curso PinhalDigital, ressaltamos que São Carlos, desde 2002, possui um programa de inclusão digital que tem se viabilizado através da implantação de telecentros em diversos pontos da cidade. 0 ргіmeiro foi instalado na Biblioteca Municipal dentro do Programa Acessa São Paulo, por meio de convênio com o governo do Estado de São Paulo. Nos anos seguintes iniciou-se um programa municipal, denominado PID - Programa de Inclusão Digital, que começou a ргomover a implantação de telecentros, através de parcerias com instituições públicas,

privadas e organizações não-governamentais, em escolas municipais de ensino básico (EMEBs), centros comunitários, bibliotecas e espaços cedidos pela comunidade (como salões de igrejas) principalmente na periferia da cidade. Além disso, ainda em 2002, teve início o projeto da Prefeitura Municipal denominado Escola do Futuro, que consiste na construção de um espaço dotado de biblioteca, sala multi-uso e sala de informática em determinadas EMEBs. Tal espaço abre-se a toda comunidade nos fins de semana.

Uma proposta de aproximação dessa política de inclusão digital ao projeto PinhalDigital, seria ргоmover, nesses telecentros já instalados na cidade, maior visibilidade ao que foi produzido pelo curso. Mas de que maneira? Рог exemplo, incentivando a realização de trabahhos didáticos sobre a história de São Carlos envolvendo alunos das EMEBs e a comunidade em geral, que se utilizariam das informações disponibilizadas na interface computacional desenvolvida no PinhalDigital рага atingir seus objetivos, despertando assim o interesse pela história local e pelo acervo da fazenda. Explorando o ambiente virtual, os usuários iriam ao mesmo tempo аргеndendo sobre o patrimônio de sua cidade e se alfabetizando digitalmente. Havendo 
a possibilidade de visitas dos usuários dos telecentros à Fazenda Pinhal após esse ргimeiro contato virtual, seria também interessante a possibilidade de postagens na interface de suas impressões sobre o local, na forma de fotografias ou textos. Essa produção colaborativa de conteúdo exigiria também uma capacitação do indivíduo no que diz respeito à digitalização e disponibilização de informação em um ambiente virtual, como ocorreu no caso da linha "Álbum fotográfico: imagens рага lembrar" do projeto de Extremadura, como já vimos. Desse modo, a partir dessa ргоposta, осоггегia um duplo ganho рага a população: um resgate de sua memória e uma potencialização de sua cultura digital.

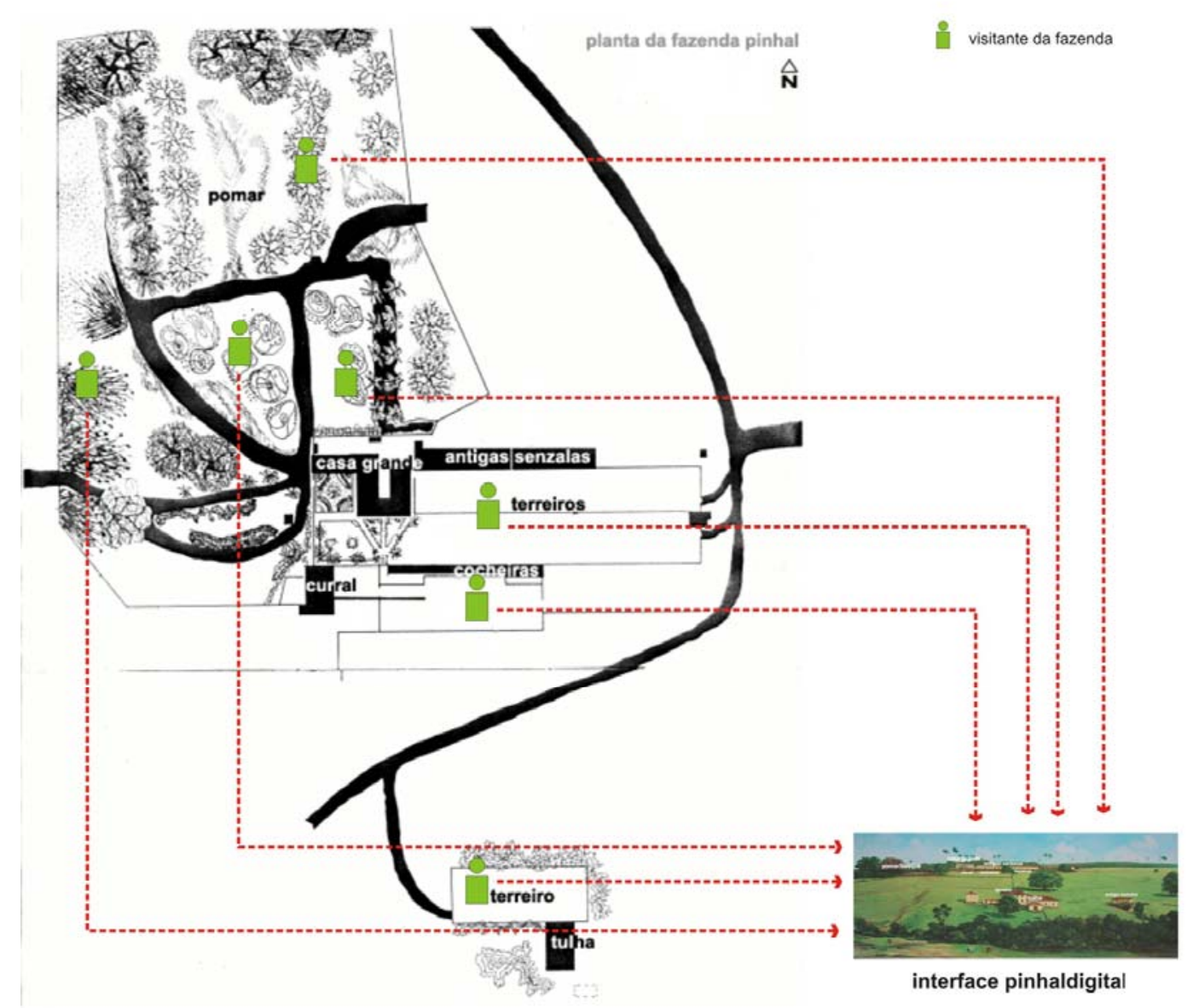

Fig.3.15: Configurando-se como uma interface colaborativa, no ambiente virtual do PinhalDigital seria possível a disponibilização das impressões dos visitantes sobre o conjunto rural., o que favoreceria a geração constante de novos conteúdos sobre o acervo da fazenda, podendo servir também como interessante ação de inclusão digital. 


\subsection{A virtualização no curso PinhalDigital}

0 objetivo da pesquisa PinhalDigital é de investigar de que forma o patrimônio visível e invisível pode ser organizado e mostrado dentro de um ambiente virtual, sem ser porém uma simulação do espaço concreto, mas sim uma complementação e um convite de dialogo do usuário com o espaço concreto e a memória a ser ргеservada [PRATSCHKE; BORTOLUCCI; SIGOLI, 2005, p.02].

0 trecho acima, referente ao objetivo do curso PinhalDigital, dialoga perfeitamente com o que constatamos anteriormente sobre a finalidade da virtualização de bens culturais. Como vimos, essa ação deveria visar um ganho, uma ampliação do entendimento do patrimônio, e não meramente uma duplicação do concreto no virtual. Tratando o ambiente virtual como uma representação realista de outra realidade [MANOVICH, 2001], e não como um simulacro da realidade concreta, a exploração de suas potencialidades poderia contribuir, de maneira inovadora, para a construção da memória coletiva, e пão орегаг apenas em termos de cópia.

Analisando a produção do projeto em questão, é possível verificar que ргоcurou-se em todas suas edições perceber o objeto de estudo sempre em uma perspectiva ampliada, utilizando-se рага isso de leituras provenientes de diversos campos disciplinares e empregando-se uma série de recursos multimídia (vídeo, áudio, modelagens tridimensionais, imagens, etc.) que poderiam enriquecer traços de sua história. Esse modo de entender a virtualização de bens culturais, aproxima-se das recomendações de instituições internacionais que incentivam projetos de preservação do patrimônio cultural com emprego da mídia digital, como o DigiCULT ${ }^{55}$ - Patrimônio Digital e Conteúdo Cultural do programa IST (Information Society Technologies) da Comissão Européia. Segundo essa organização,

0 trabalho sobre projetos de patrimônio cultural deverá explorar conhecimentos emergentes e tecnologias de visualização para criar novas formas de experiência cultural, e рага desenvolver novas formas de expressão e паггаtivas рага diferentes comunidades [DIGICULT, 2005].

Embora não tenha sido totalmente desenvolvida, durante as atividades do PinhalDigital, pensou-se em uma aplicação que aumentaria o conhecimento do acervo da

\footnotetext{
${ }^{55}$ Mais informações disponíveis em: <http://cordis.europa.eu/ist/digicult/index.html>.
} 
fazenda baseada na realização de fotos panorâmicas de vários espaços do conjunto гural. A idéia ега disponibilizar tais fotos, que permitem a ilusão de imersão no ambiente retratado, com deslocamento visual de 360 graus a partir de um ponto fixo, em cada um dos edifícios da pintura digitalizada de Calixto. Às fotos panorâmicas se sobreporia um levantamento de informações (no formato de fotos e textos) referentes a objetos, como a mobília, quadros, porta-retratos, louças, entre outros, que estavam presentes nos espaços retratados. Mesclando-se as fotos panorâmicas e os levantamentos como camadas de conhecimento, seria possível a geração de visualizações dos interiores do conjunto rural, com a possibilidade de interação com os objetos da cena - algo que se assemelharia ao projeto Kidai Shôran que já apresentamos. Navegando nos espaços, o usuário, escolhendo e clicando os objetos de seu interesse, seria conduzido a links específicos, adquirindo, por meio deles informações adicionais sobre a cena, em um processo de aprendizado não linear, que ampliaria o entendimento daquele patrimônio.

No diagrama que propomos abaixo, podemos visualizar esquematicamente a navegação nessa interface: 


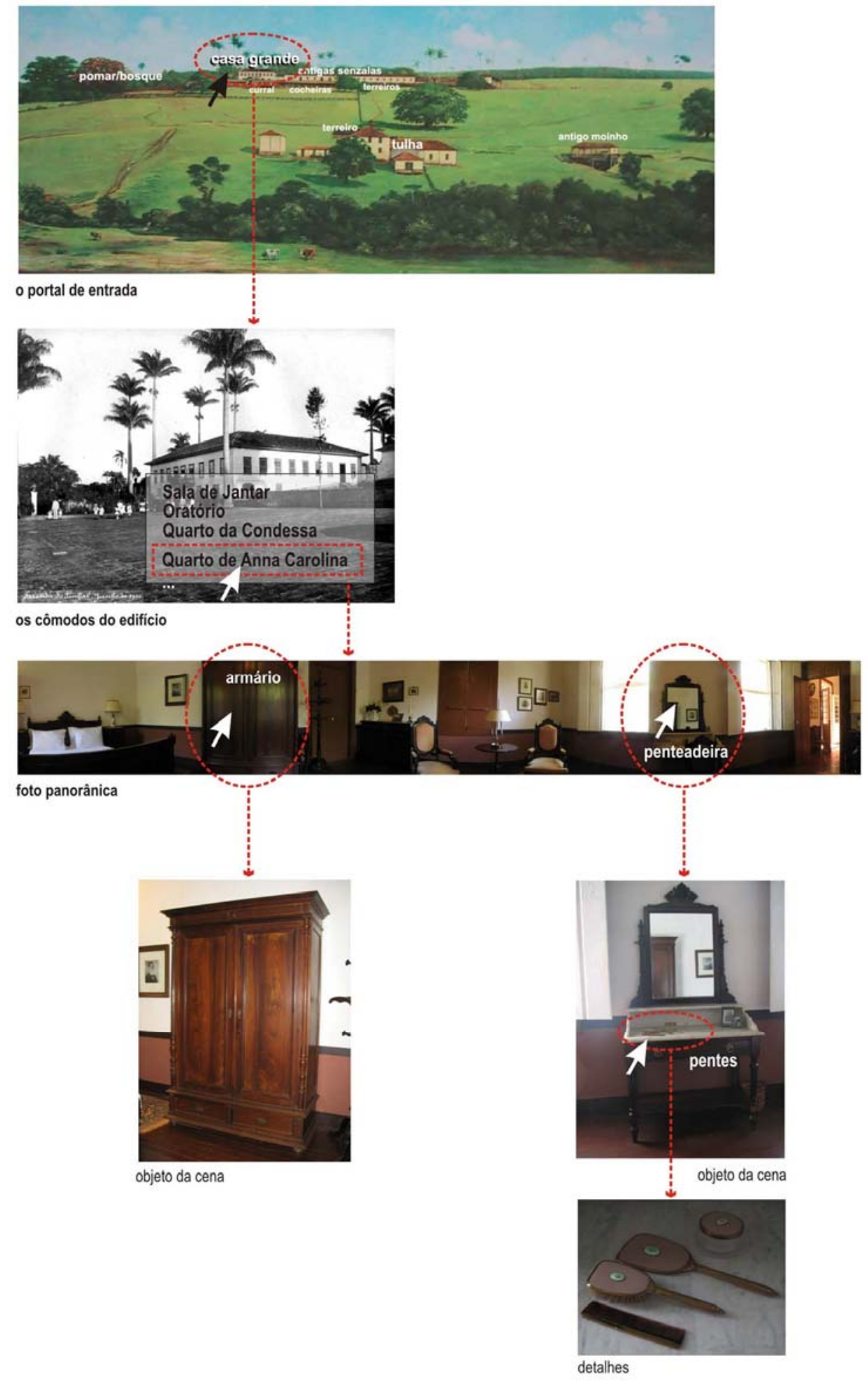

Fig.3.16: Diagrama da navegação na interface computacional PinhalDigital.

Uma outra interessante atividade de virtualização de um bem cultural da Fazenda Pinhal foi o registro de um patrimônio imaterial, personificado, entre outras 
formas, na figura de um antigo jardineiro da fazenda, o 'Seo' José, cujo trecho de seu depoimento inicia este capítulo.

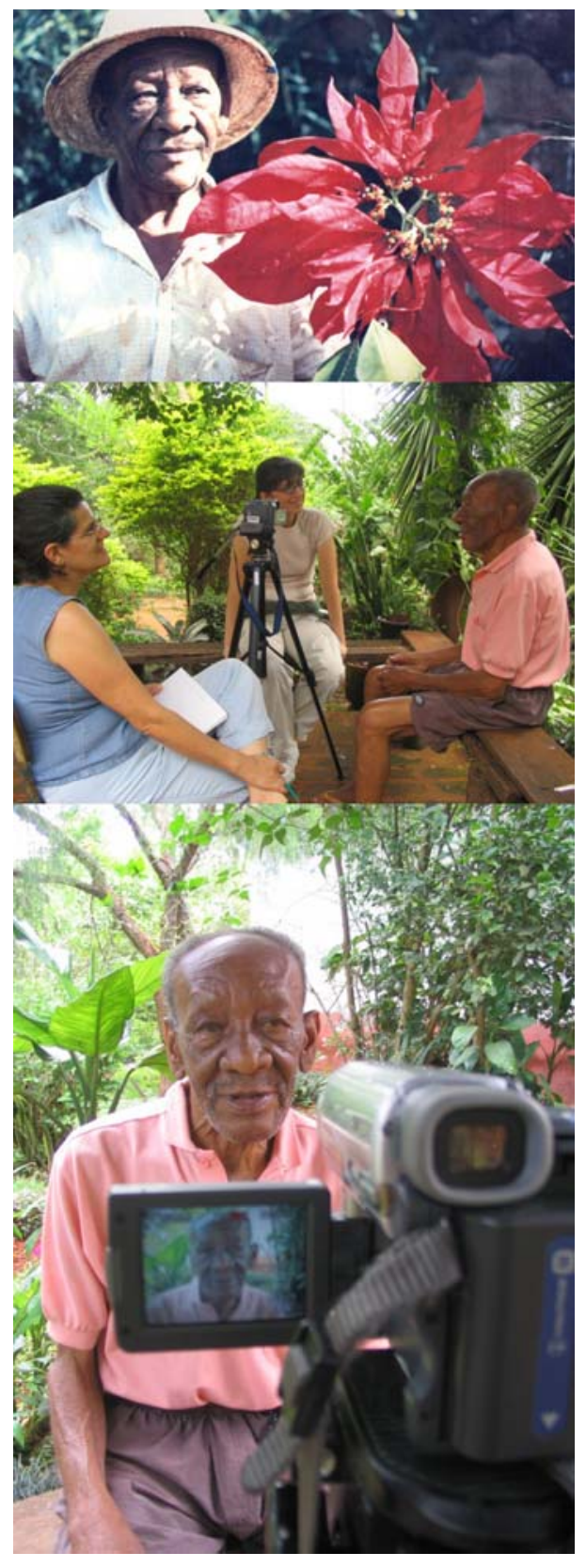

Fig.3.17: As memórias do velho jardineiro da Fazenda Pinhal sendo registradas.
Esse registro foi documentado em vídeo digital, que seria acessado a partir da interface desenvolvida no curso. Realizado durante o PinhalDigital 3, em 2005, tratouse de uma entrevista que teve como objetivo fazer vir a tona antigas histórias da Fazenda Pinhal guardadas por 'Seo'José, uma espécie de "homem-memória", usando os termos de Balandier [1974], que, рог intermédio de suas recordações pessoais e das recordações recebidas de sua sogra, Dona Leonor, e de sua esposa, Dona Virgínia, que conviveram diretamente com figuras históricas da fazenda, como a Condessa do Pinhal e sua escrava particular, conhecida como Dona Maria Preta, fizeram com que ele se tornasse um guardião das lembranças do lugar. Bosi [1983, p.56] observou que

Um mundo social que possui uma riqueza e uma diversidade que não conhecemos pode chegar-se pela memória dos velhos. Momentos desse mundo perdido podem ser compreendidos por quem não viveu e até humanizar o presente.

A presença de 'Seo' José na fazenda parecia funcionar justamente como uma fonte rica e viva de rememoração do passado local. Segundo o depoimento dado, há sessenta anos ele havia chegado na propriedade, logo após a morte da Condessa. Trabalhando inicialmente com gado, 'Seo' José depois foi carroceiro, até ocupar a 
função de jardineiro que exercia até aquele momento. Entendemos que esse foi um dos trabalhos dentro das atividades do PinhalDigital que ilustram melhor o potencial que 0 emprego das tecnologias informacionais pode †ег па ргеservação de bens culturais e na construção da memória. 'Seo' José faleceu em 2006, mas suas histórias, que antes nunca haviam sido documentadas, agora ainda têm a possibilidade de serem contadas.

\subsection{Os sistemas no curso PinhalDigital}

"Os interesses sobre a localidade, naturalmente, pedem um grau de detalhamento do conhecimento que merece atenção no momento de se adotar metodologias de levantamentos, de se conceber sistemas de organização, e de se ргоjetar as interfaces de acesso" [BLAIKIE, 1996 apud PRATSCHKE; BORTOLUCCI; SIGOLI, 2005, p.1].

Como vimos, em um trabalho que envolveu diversos pesquisadores e campos disciplinares, um grande volume de informações do rico acervo da Fazenda Pinhal foi levantado e registrado. Procurou-se organizar esse vasto conteúdo com a utilização de um software específico, o i-class, um protótipo de um sistema de classificação de bens culturais que esta sendo atualmente utilizado em um projeto que envolve a catalogação de todo patrimônio cultural da cidade de São Carlos e região, denominado Memória Virtual.

Embora tenha ocorrido o emprego desse software, foi necessário, durante o PinhalDigital 3, uma pausa em novos levantamentos, рага que fosse possível a organização do material já disponível dos anos anteriores, o que não pode ser completamente finalizado por motivos de tempo disponível para a ação.

No entanto, o foco de nossa discussão sobre a organização de informações referentes a bens culturais no ambiente virtual é outro. Como discutimos no capítulo anterior, nossa reflexão não baseou-se em estabelecimentos de parâmetros técnicos рага o desenvolvimento de sistemas de organização, como o i-class. Entendemos que essa tarefa é própria de profissionais dos campos das ciências de computação, que 
atuam diretamente na construção e desenvolvimento de software. Nosso estudo, especificamente, voltou-se рага o entendimento do ргоcesso, e па̃o рага técnica empregada, de organização das informações nos sistemas, isto é, рага um pensar sistêmico que poderia ser empregado em projetos de ргеservação patrimonial рог meio da mídia digital. Рara esse entendimento, nos aproximamos da Teoria Cibernética.

Mesmo que grande parte dos levantamentos e dos conteúdos criados durante 0 PinhalDigital não tenham sido reunidos e disponibilizados em uma interface computacional já completamente implantada, verifica-se, ao longo de suas edições, a aplicação de um pensamento sistêmico na organização dessas informações dentro do ambiente virtual. Podemos dizer que essa organização baseou-se, mesmo que inconscientemente, no princípio cibernético de Bateson de que o "o mapa não é o †еггitório". Рrocessou-se, nas atividades realizadas no conjunto rural, a passagem das informações descodificadas do território, no caso a Fazenda Pinhal, para o mapa, no caso o sistema virtual, na forma de informações codificadas. Essa passagem baseou-se no emprego intenso das tecnologias informacionais na realização dos levantamentos in loco. Relembramos que as informações organizadas em um mapa são o resultado de filtragens e seleções por um atores/observadores, papel desempenhado no PinhalDigital pelos pesquisadores envolvidos no projeto. A tradução do †еггitório ao mapa não deve consistir simplesmente na duplicação do bem cultural no meio virtual, pois o mapa não é o território. Se assim o fosse, o mapa perderia sua razão de existir [EPSTEIN, 1973]. Teríamos uma redundância ou excesso de informação que não contribuiria para a construção de novos conhecimentos.

Observamos que mesmo ainda não reunidos em uma interface final, o esforço de confeç̧ão de "mapas" da Fazenda Pinhal já pôde gerar novos saberes sobre seu "†еггitório" рага os pesquisadores. E quanto mais o conhecimento do †егritório, mais informações serão transferidas para o mapa. Forma-se assim a relação de retroalimentação informativa (feedback) [FORTE, 2007] entre o conjunto rural e o ambiente virtual, que contribui рага um aprofundamento no entendimento dos bens culturais ali presentes. 
Um exemplo que ilustra a tradução de um patrimônio cultural da fazenda para o ambiente virtual, baseada no princípio do mapa e território, é o processo de digitalização da Tulha, iniciado durante a primeira edição do PinhalDigital, em 2003. Tomando esse edifício como o tеггitório, selecionou-se aspectos de sua realidade que se pretendia descrever, como num processo de elaboração de um mapa, segundo o ciberneticista Isaac Epstein [1973]. Essa seleção, realizada por pesquisadores de diversos campos disciplinares, favoreceu a estruturação e organização de conteúdos através de múltiplos olhares. 0 resultado foi a possibilidade de reconstrução da tulha no ambiente virtual, a partir de diversas leituras laspectos físicos e construtivos, modos de vida, história local, memória oral, entre outros) e camadas de conhecimento a elas relacionadas. Dessa forma, não operou-se simplesmente como uma duplicação no virtual, como осогге no caso de experiência de modelagens virtuais em três dimensões. Assim, novos saberes sobre o objeto de estudo foram gerados e aumentou-se sua compreensão.

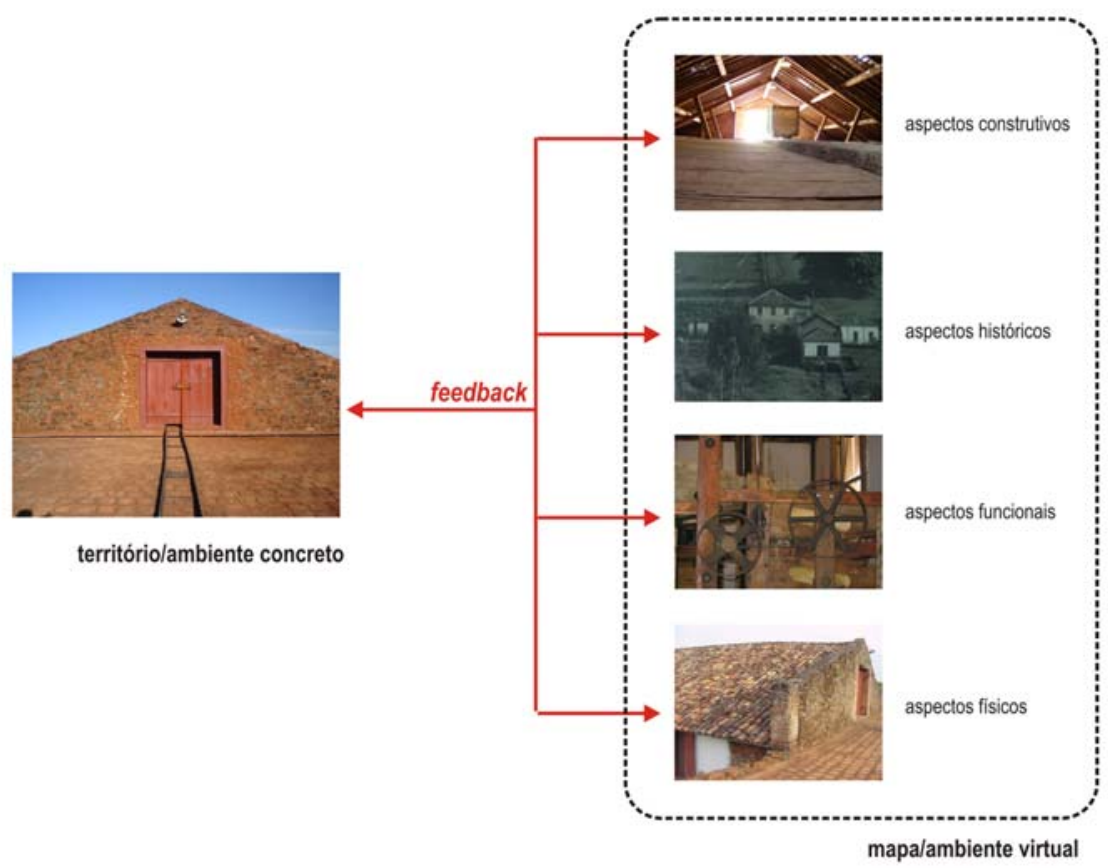

Fig.3.18: A transferência e organização das informações da tulha ao ambiente virtual, baseando-se na Teoria Cibernética, segundo o princípio do mapa e território.

\subsection{Considerações}

0 curso de extensão universitária PinhalDigital foi uma experiência inovadora de 
ргеservação de bens culturais [PRATSCHKE, 2004], que procurou contribuir рага a construção da memória local, especificamente aquela referente à cidade de São Carlos e região. Inovadora porque, utilizando-se intensamente das Tecnologias de Informação e Comunicação, conseguiu reunir uma grande constelação de pesquisadores de diferentes formações e interesses, dialogando, em um trabalho fundamentalmente colaborativo, inter e transdisciplinar, aо геdor do estudo de um importante patrimônio cultural, o que proporcionou olhares múltiplos sobre este.

Explorando intensamente as novas potencialidades que as tecnologias computacionais oferecem no registro dos bens culturais, um grande volume de informações foi gerado durante as quatro edições do curso, realizadas entre 2003 e 2006. Classificando tais informações, nota-se que elas consistiram basicamente em desenhos (esboços e croquis digitalizados, desenhos técnicos em CAD e storyboards); imagens (levantamentos fotográficos e registro de atividades dos grupos); sons e vídeos (depoimentos dos pesquisadores, entrevistas com os personagens da fazenda e making offs); e textos (sobre a história da Fazenda Pinhal; sobre as atividades desenvolvidas e relatórios). Além disso, essa experiência rendeu algumas publicações, como artigos apresentados em congressos ${ }^{56}$ e especialmente a formação e sensibilização dos pesquisadores envolvidos em relação ao patrimônio e o uso da mídia.

A compreensão do acervo da fazenda potencializou-se a partir do PinhalDigital, que рroduziu efeitos bastante positivos, como a ргópria геorganização da fazenda. A atividade de digitalização da Tulha, por exemplo, acabou por influenciar e incentivar os ргоргietários da fazenda na гесuperação física do local, na гесompra dos equipamentos de beneficiamento de café e no replantio do café. Destacamos também que o curso, integrando-se com o Projeto de Políticas Públicas Memória Virtual, foi um momento importante de testes de sistemas de classificação de bens culturais, onde pôde-se геver alguns aspectos do software, contribuindo рага seu aperfeiçoamento.

\footnotetext{
${ }^{56} 0$ artigo "Mesclando realidades: olhares múltiplos sobre um patrimônio rural", das pesquisadoras Anja Pratschke, Maria Ângela Bortolucci e Luzia Sigoli, apresentado no Congresso Internacional do CICOP Centro Internacional para Preservação do Patrimônio <http://www.cicopar.com.ar/congresos_cicop.htm>, realizado na Argentina, em 2006, apresentou a experiência do curso.
} 
Vale ressaltar que não é previsto um produto final do PinhalDigital, mas um registro contínuo da história a ser disponibilizado em um sistema multimídia linterface computacional) que possa mostrar os aspectos formais, construtivos, funcionais, históricos e culturais [PRATSCHKE; BORTOLUCCI; SIGOLI, 2005, p.4] геferente à Fazenda Pinhal.

Tendo participado de duas edições do curso, vemos como um de seus grandes resultados a conciliação de ensino e pesquisa em uma mesma prática acadêmica, que propiciou integração e transdisciplinaridade, como já observado por Pratschke [2004]. Além disso, podemos dizer que os três fatores constatados anteriormente - a comunicação, a virtualização e os sistemas -, através dos quais se viabilizaria a relação entre o patrimônio/memória e as tecnologias informacionais, estiveram, em sua maioria, ргеsentes, em maior ou menor grau, na proposição do PinhalDigital. Mesmo a comunicação voltada à inclusão digital, que não se tratou de um dos objetivos do curso, nos pareceu algo que poderia ser perfeitamente explorado.

Nossa observação final é a necessidade fundamental de se completar a implantação da interface computacional do curso, disponibilizando à população todos os conteúdos gerados sobre o rico patrimônio material e imaterial da Fazenda Pinhal, esses vestígios através dos quais poderiam se ancorar nossa memória coletiva.

Isso talvez pudesse ser viabilizado a partir de outro formato de trabalho, como рог exemplo um projeto de pesquisa, e não mais através de uma nova edição do PinhalDigital. Acreditamos, dado o volume de informações armazenadas, que a ação final de disponibilização dos conteúdos não se resumiria apenas a mais 64 horas de trabalho, como foram todas as edições do curso. Uma proposição seria um trabalho contínuo sobre os vastos dados coletados, que poderia ser viabilizado por pesquisadores já graduados, auxiliados talvez por bolsa de treinamento técnico. 


\section{Considerações finais}


Durante o período do Modernismo, que abrangeu boa parte do século passado, arquitetos como Walter Gropius, passaram a defender a idéia de uma "arquitetura total", que compreenderia, pautando-se em um racionalismo metodológico-didático [ARGAN, 1998], em uma atuação universalista do arquiteto, abrangendo desde o projeto de grandes planos urbanísticos até o design de simples objetos cotidianos. Assim, naquele momento, ao contrário de que ocorreu com outras profissões como a engenharia, que se especializaria em uma série de ramos, o arquiteto acabou por ampliar seu campo de ação, o que veio a implicar em uma formação cada vez mais plural, exigindo-lhe conhecimentos cada vez mais multidisciplinares [PRATSCHKE, TRAMONTANO, MOREIRA, 2000].

Hoje, nos primeiros anos do século XXI, esse perfil multidisciplinar рагеce auxiliar o arquiteto na exploração de novos campos, como os surgidos com o advento do atual ambiente tecnológico, que vem se desenhando nas últimas três décadas através da convergência entre mídia, computação e telecomunicações. Nele ocorreu a emergência de uma modalidade de espaço ou realidade - a virtual, que vem se convertendo em um rico campo de experimentações ao arquiteto, historicamente o construtor do espaço concreto.

Em uma realidade que atualmente se amplia, onde, à espacialidade concreta, soma-se a virtual, o foco de nossas preocupações na presente dissertação de mestrado voltou-se especificamente à investigação das implicações de um ambiente híbrido para o patrimônio cultural, cuja preservação é um tema tradicional de estudos dentro do campo disciplinar da Arquitetura. Tarefa árdua, que exigiu o contato com diversas áreas do conhecimento, onde nossa formação multidisciplinar foi fundamental па ргосига рог estabelecimento de novos diálogos.

Dentro desses limites da pesquisa, tendo como cenário o estado da cultura e da tecnologia no mundo contemporâneo, o primeiro passo dado foi fundamentar teoricamente cada um dos temas relacionados ao trabalho (patrimônio cultural, memória social e mídial рага que fossem trabalhados ao longo da dissertação, algo que conseqüentemente acabou já respondendo algumas de nossas perguntas iniciais. Verificou-se, a partir das primeiras conceituações, em que medida ligava-se cada um 
desses temas. Constatamos que o patrimônio cultural, que hoje abrange um vasto conjunto de bens, tanto materiais quanto imateriais, funciona como uma espécie de ponto de apoio ou externalização onde a memória social ancora-se. Essa memória, uma reconstrução ou manifestação continuamente atualizada do passado, é importante porque fala da identidade cultural. Nela permanece uma continuidade cultural que "comporta modificações e alterações num processo aberto e flexível, de constante realimentação, o que garante a uma cultura sua sobrevivência. Рага seu desenvolvimento harmonioso, pressupõe a consciência de um largo segmento do passado histórico" [MAGALHÃES, 1997, p.51]. Ргеservar o patrimônio seria então орегаг em um dos meios pelos quais é possível a tomada de consciência desse passado, que, sendo геinterргеtado рог novas gerações, segundo os contextos históricos, culturais e sociais em que elas estão inseridas no momento, contribuiria para sua atualização, e assim рага a construção e evolução da memória social.

Verificamos também que essa memória, enraizada no patrimônio cultural, sempre foi influenciada pelos meios de comunicação dominantes de um determinado momento da História. Vimos que nas sociedades sem escrita, os chamados "homens-memória" eгam seus guardiões. No entanto, com a invenção do alfabeto fonético, a memória pela ргimeira vez libertou-se de suportes físicos, projetando-se para fora do indivíduo com a escrita. Os impressos multiplicaram exorbitantemente essa memória disponível, assim como os meios audiovisuais, que, como nenhum outro, ofereceram as mais impressionantes possibilidades de "sobrevida dos desaparecidos" em imagens e sons, como observou Debray [1993]. Dessa forma, atualmente, com a crescente expansão e popularização da mídia digital, que vem se tornando, cada dia mais, a mídia dominante, entendemos que seria então uma evolução natural a construção da memória se processar influenciada por seus meios.

Uma dessas formas poderia ser justamente através do patrimônio traduzido ao ambiente virtual. Apoiando-se em reflexões de pesquisadores sobre o assunto, pensouse em três abordagens possíveis para a viabilização dessa ação, que se apresentaram segundo a comunicação, a virtualização e os sistemas. Refletindo-se a respeito desses três pontos, pudemos verificar como se dariam os ganhos para a própria ampliação da 
compreensão dos bens culturais, e, consequentemente рага o desenvolvimento da memória.

Vimos que a comunicação no contexto da digitalização do patrimônio refere-se ao modo de se acessar seus conteúdos. Disponibilizado no ambiente virtual, expande-se, mais democraticamente a acessibilidade a suas informações. Além disso, as tecnologias informacionais permitem uma reconfiguração de práticas na comunicação, permitindo que os antigos receptores tornem-se também produtores de conteúdo, o que poderia, рог exemplo, ser еmpregado em políticas de incentivo à inclusão digital.

Já a virtualização no contexto da digitalização do patrimônio cultural, relacionase ao modo de se converter os bens culturais à espacialidade virtual. Em discussões que tocaram em pontos importantes como autenticidade, original, falso entre outros, entendemos que o espaço virtual poderia ser encarado não em termos de cópia da realidade concreta, mas como uma realista representação de outra realidade. Nãolinearidade, interação, recursos multimídia, entre outros, poderiam ser justamente algumas das características desse ambiente a serem exploradas, gerando novos saberes sobre o bem cultural concreto.

E por final, refletimos sobre os sistemas no contexto da digitalização do patrimônio cultural, que геfere-se ao modo de se organizar os conteúdos relativos a bens culturais no ambiente virtual. Apoiando-se na Teoria Cibernética, verificamos que a tradução do patrimônio à espacialidade virtual se processa de modo semelhante como uma organização de informações de um território em um mapa. Assim, essa não deve consistir em uma duplicação do concreto no virtual, pois o mapa não é o território. Se assim o fosse haveria um redundância de informações que não contribuiria рага a construção de novos conhecimentos. Havendo diferença entre o mapa (virtual) e o território (concreto), segundo a cibernética estabelece-se um fluxo informativo entre ambos (feedback), e a produção de um maior aprendizado do bem cultural em questão.

Concluindo nossas considerações finais, destacamos alguns pontos de nossos estudos sobre as experiências que envolvem patrimônio cultural/memória social e mídia 
digital que poderiam contribuir e indicar caminhos para a realização de futuros trabalhos sobre o tema:

- A riqueza maior dessas experiências residiria na mesclagem entre as espacialidades concreta e virtual, quando novos saberes são construídos. A passagem do patrimônio ao ambiente virtual pode gerar novos conhecimentos que acabariam retornando ao objeto concreto na forma de uma ampliação de sua compreensão (feedback);

- Рагеce haver grande potencial de suas aplicações atreladas a projetos que promovem inclusão digital. Ressaltamos que essa inclusão não seria somente aquela ligada a populações de baixa renda, mas também uma que se direcionaria ao próprio estudioso de bens culturais, como o historiador ou sociólogo, quebrando preconceitos, expandindo os limites de compreensão do patrimônio por esses;

- Diferente da escrita, que caracteriza-se como uma experiência linear, com início, meio e fim, o que teríamos hoje, com a meio digital, seriam experiências caracterizadas pela não-linearidade. As seqüências ordenadas dariam lugar a "meios" e que gerariam outros "inícios" ou a "fins" que gerariam outros "meios" e "começos". Desse modo, não se poderia falar em um produto único e final de uma experiência que envolva patrimônio e mídia digital. Tais experiências não аргеsentariam um produto completamente fechado, principalmente se realizadas em colaboração. Рог exemplo, o аргеndizado gerado no processo colaborativo de design do ambiente virtual onde será disponibilizado o bem cultural digitalizado já se constituiria, рог si só, um ргoduto, como осоггеu no curso PinhalDigital. Além disso, se além do design, o ambiente virtual †ambém suportar colaboração, isso tornaria possível contínuas agregações de conteúdo, o que enriquece muito a experiência;

- Equipes multidisciplinares podem ргорогcionar olhares múltiplos sobre o bem cultural, o que consistiria em um ganho importante na tradução desse bem ao ambiente virtual, na medida em que proporcionaria aos seus usuários uma 
compreensão ampliada complexa do bem em questão, em diversas camadas de conhecimento;

- Мeras modelagens digitais de bens culturais não se converteriam, em nossa opinião, em ganhos significativos a sua compreensão, орегando mais como simples duplicação do concreto no virtual. Essas experiências deveriam ser direcionadas para disponibilização de múltiplas informações, como aspectos construtivos, físicos, históricos, de modos de vida, entre outros, que enriqueceriam mais o estudo dos bens em questão;

- Experiências de reconstrução virtual, рor exemplo, de edifícios de valor históricos que já desapareceram, seriam válidas na medida em que se apoiam em materiais que documentaram sua existência. Desse modo, embora não existam mais, não осоггегіa a perda de vista de seus aspectos concretos;

- E por final, o patrimônio cultural a ser traduzido à espacialidade virtual não deveria, em nossa opinião, nunca perder sua referência concreta, pois essa ação faz parte de um processo de estabelecimento de valores e significados que se quer ргеservar do objeto concreto. Sem ele, não se estabeleceria a geгаção de novos saberes da mesclagem entre o concreto e virtual.

Assim, finalizamos essa dissertação que procurou ampliar o "ver" o patrimônio cultural. Como disse Pierre Teilhard de Chardin, "a história do mundo é a história da elaboração de olhos cada vez mais perfeitos" [CHARDIN, 1995, p.5]. Dessa forma, discernindo o patrimônio cultural cada vez mais, acreditamos que seja possível conhecêlo cada vez mais. Guiados por esse pensamento, esperamos que essa pesquisa, que explorou reflexões sobre memória, patrimônio cultural em ambientes digitais, tenha contribuído efetivamente рага esse discernimento e que incentive outros trabalhos nesse campo de estudos ainda pouco explorado. 
Referências 
ACCIOLY, M.I. (2006). A Simulação па егa da convergência digital. Revista Razon y Palabra, .53. out./nov. Disponivel em:<http://www.razonypalabra.org.mx/ anteriores/n53/maccioly.html>. Acesso em: 23 mar. 2007.

ARGAN, G.C. (1998). Arte moderna. São Paulo: Cia das Letras.

BALANDIER, G. (1974). Antropológicas. São Paulo: Centauro.

BATESON, G. (1980). Mind and nature: a necessary unity. New York: A Bantam New Age Book.

BATESON, G. (1987). Steps to an ecology of mind. New Jersey: A Jason Aronson.

BAUDRILLARD, J. (1981). Simulacros e simulações. Lisboa: Relógio D’Água.

BENINCASA, V. (2003). Velhas fazendas: агquitetura e cotidiano nos campos de Агагаquага, 1830-1930. São Carlos: EdUFSCаг.

BENJAMIN, W. (1987). Obras escolhidas. São Paulo: Brasiliense.

BERNARDO, G. (2005). A Dúvida de Flusser. Rio de Janeiro: Globo.

BeRTALANFFY, L.V. (1977). Teoria geral dos sistemas. Petrópolis: Vozes.

BORGES, J.L. (1990). Memória. In: STORTINI, C. (0rg.). O Dicionário de Borges: o Borges oral, o Borges das declarações e das polêmicas. Rio de Janeiro: Вertrand. p.35.

BORRA, D. et al. (2004). Mindscape: ecological thinking, cyber-antropology, and virtual archaeological landscapes. Oxford: Аrchaeopress.

BOSI, E. (1981). Memória e sociedade: lembranças de velhos. São Paulo: T.a Queiroz.

BOURDIEU, P. (1987). A Economia das trocas simbólicas. São Paulo: Perspectiva.

BRIGGS, A.; BURKE, P. (2004). Uma História social da mídia: de Gutenberg à Internet. Rio de Janeiro: Jorge Zahar.

BURKE, P. (2000). Variedades de história cultural. Rio de Janeiro: Civilização Вrasileira.

CAMERON, F. (2007). Beyond the cult of the replicant: museums and historical digital objects. In: CAMERON, F.; KENDERDINE, S. (Ed.). Theorizing digital cultural heritage: a critical discourse (Media in Transition). Cambridge: MIT. p.49-75.

CAMPELLO, B. (1998). Formas de expressão do conhecimento. São Paulo: Atlas.

CARR, E.H. (1989). Que é história?. São Paulo: Paz е Теггa. 
CARTA de Atenas. (2004). In: CURY, I. Cartas patrimoniais. Rio de Janeiro: IPHAN. p.1368.

CASTELLS, M. (1999). A Sociedade em rede. А ега da informação: economia, sociedade e cultura. São Paulo: Paz e Тегга. v.1.

(2001). La Galaxia Internet. Barcelona: Plaza y Janes.

CAVALCANTE, B. (2000). Ser moderno: a propósito de uma tradição. Semear, Rio de Janeiro, v.4, p.115-127.

CERUZZI, P. (2003). A History of modern computing. Cambridge: MIT.

CHOAY, F. (2001). A Alegoria do patrimônio. São Paulo: Ed.UNESP.

COSTA, L.; PESSOA, J. (2004). Lucio Costa: documentos de trabalho. Rio de Janeiro: IPHAN.

CUNHA, A. (1982). Dicionário etimológico nova fronteira da língua portuguesa. Rio de Janeiro: Nova Fronteira.

CURY, I. (0rg.). (2004). Cartas patrimoniais. Rio de Janeiro: IPHAN.

DEBRAY, R. (1991). Curso de midiologia geral. Petrópolis: Vozes.

(1994). Manifestos midiológicos. Petrópolis: Vozes.

DECRETO-Lei n.25, 30.11.1937. (2004). In: CURY, І. (0rg.). Cartas Patrimoniais. Rio de Janeir o: IPHAN.

DIGICULT TECHNOLOGY CHALLENGES FOR DIGITAL CULTURE (2006). Digital heritage and cultural contend. Disponivel em:<http://www.digicult.info/pages/index.php>. Acesso em: 30 ago. 2006.

DODEBEI, V. (2005). Memória, circunstância e movimento. In: GONDAR, J.; DODEBEI, V. (0rg.). 0 Que é memória social?. Rio de Janeiro: Contra Capa. p.43-54.

EUROPEAN CULTURAL HERITAGE ONLINE (2006). Disponivel em:<http://echo2.mpiwgberlin.mpg.de/home>. Acessado em: 14 out. 2006.

ECO, U. (1987). Apocalípticos e Integrados. São Paulo: Perspectiva.

EPSTEIN, I. (1973). Uma Máquina que aprende (Gabriela I). In: EPSTEIN, I. (0rg.). Cibernética e comunicação. São Paulo: Cultrix. p.165-190. 
FAULKNER, C. (1998). The Essence of human-computer interaction. London: Prentice Hall.

FEATHERSTONE, M. (2005). Arquivando culturas. In: __. Informação e conhecimento: аргоximando áreas de saber. São Carlos: EdUFSCar. p.8-20

FENTRESS, W.; WICKHAM, J. (1992). Social memory. Oxford: Blackwell.

FERNANDES, J. (2000). Ciberespaço: modelos, tecnologias, aplicações e perspectivas. Recife: UFPE.

FERREIRA, G.M. (2001). As Origens recentes: os meios de comunicação pelo viés do paradigma da sociedade de massa. In:

Teorias da comunicação: conceitos, escolas e tendências. Petrópolis: Vozes.

FERREIRA, M. (2005). A Proposal for a collaborative environment for the early stages of product design. São Carlos: EESC/USP.

FLUSSER, V. (1983). Pós-história: 20 instantâneos e um modo de usar. São Paulo: Duas Cidades.

FLYNN, B. (2007). The Morphology of space in the virtual heritage. In: CAMERON, F.; KENDERDINE, S. (Ed.). Theorizing digital cultural heritage: a critical discourse (Media in Transition). Cambridge: MIT. p.349-368.

FONSECA, M.F. (1997). O Patrimônio em processo: †rajetória da política federal de ргеservação no Вrasil. Rio de Janeiro: Ed.UFRJ; IPHAN.

FORTE, M. (2007). Ecological cybernetics, virtual reality, and virtual heritage. In: CAMERON, F.; KENDERDINE, S. (Ed.). Theorizing digital cultural heritage: a critical discourse (Media in Transition). Cambridge: MIT. p.389-407.

FRAMPTON, K. (1997). História crítica da arquitetura moderna. São Paulo: Martins Fontes.

GARIN, E. (1996). Ciência e vida civil no renascimento italiano. São Paulo: Ed.UNESP.

GLANVILLE, R. (2007). The Purpose of second-order cybernetics. Disponivel em:<wWW.emeraldinsight.com/researchregister>. Acessado em: 5 set. 2007.

GONDAR, J. (2005). Quatro proposições sobre memória social. In: GONDAR, J.; DODEBEl, V. (0rg.). 0 Que é memória social?. Rio de Janeiro: Contra Capa. p.11-26.

GONDAR, J.; DODEBEI, V. (0rg.) (2005). O Que é memória social?. Rio de Janeiro: Contra Capa. 
GOODY, J. (1977). A Domesticação da mente selvagem. São Paulo: [s.n.].

GORDINHO, M.C. (1985). A Casa do pinhal. São Paulo: C.H.Knapp.

GROPIUS, W. (1972). Bauhaus: novarquitetura. São Paulo: Perspectiva.

HALBWACHS, M. (2006). A Memória coletiva. São Paulo: Centauro.

HOHLFELDT, A. (2001). Teorias da comunicação: conceitos, escolas e tendências. Petrópolis: Vozes.

HUYSSEN, A. (2000). Seduzidos pela memória. Rio de Janeiro: Aeroplano.

INSTITUTO DO PATRIMÔNIO HISTÓRICO E ARTÍSTICO NACIONAL (2007). 0 Patrimônio cultural. Disponível em:<http://portal.iphan.gov.br>. Acesso em: 27 jan. 2007.

JEUDY, H.P. (1990). Memórias do social. Rio de Janeiro: Forense-Universitária.

LAUREL, B. (1992). The Art of human-computer interface design. New York: AddisonWesley.

LE GOFF, J. (2003). História e memória. Campinas: Ed.UNICAMP.

LEROI-GOURHAN, A. (1983). O Gesto e a palavra. Lisboa: Ed.70.

LÉVY, P. (2003). Cibercultura. São Paulo: Ed.34.

LÉVY, P. (1996). O Que é virtual?. Tradução de Paulo Neves. São Paulo: Ed. 34.

LUHMANN, N. (1995). A Obгa de arte e a auto-гергodução da arte. In: História de literatura: as novas teorias alemãs. São Paulo: Ática. p.23-57.

MAgALHÃES, A. (1997). E Triunfo? A questão dos bens culturais no Brasil. Rio de Janeiro: Nova Fronteira.

MANOVICH, L. (2001). The Language of new media. Cambridge: MIT.

MARTEGANI, P.; MONTEnEGRO, R. (2001). Digital design: new frontiers for the objects. Basel: Birkhäuser.

MARTINO, L.C. (2004). Interdisciplinaridade e objeto de estudo da comunicação. Psicologia: ciência e profissão, Вгаsília, n.4, p.268.

MCLUHAN, M. (1971). Os Meios de comunicação como extensões do homem. São Paulo: Cultrix. 
MCLUHAN, M. (1969). The Playboy interview: a candid conversation with the high priest of popcult and metaphysician of media. Disponivel em: <http://WWw.eesc.usp.br/nomads/textos/index.htm>. Acesso em: 12 jun. 2007

MESTAOUI, N.; KACl, Y. (2006). Electronic shadow. Revista Eletrônica Nomads.USP V!RUS. em:<http//:WWw.eesc.usp.br/nomads/virus01/electronicshadow/entrevista>. Acesso em: 23 ago. 2006.

MESTAOUI, N.; KACl, Y. (2006). Hybrid realities. Paris: Archibooks.

MOLES, A. (1973). Cibernética e ação. In: EPSTEIN, I. (0rg.). Cibernética e comunicação. São Paulo: Cultrix. p.83-128.

MONTANER, J.M. (2002). Depois do movimento moderno: arquitetura da segunda metade do século XX. Barcelona: Gustavo Gili.

MUMFORD, L. (1998). A Cidade na história: suas origens, transformações e perspectivas. São Paulo: Martins Fontes.

NEGRoPonte, N. (2000). A Vida digital. São Paulo: Companhia das Letras.

NORA, P. (1993). Entre memória e história: a problemática dos lugares. Projeto História, São Paulo, n 10, p. 7-28, dez. 1993.

NORMAS de Quito. (2004). CURY, I. Cartas patrimoniais. Rio de Janeiro: IPHAN. p.105122.

ORGANIZAÇÃO DAS NAÇÕES UNIDAS PARA A EDUCAÇÃO, CIÊNCIA E CULTURA (1972). Convenção para a proteção do patrimônio mundial, cultural e natural. UNESCO. Disponivel em:<http://whc.unesco.org/documents/publi_basictexts_pt.pdf>. Acesso em: 10 fev. 2007.

Disponível

(1975). Os Esquimós, um povo que não quer desaparecer. UNESCO. bin/sysbibli/sysbweb.exe/dados completos html?codigo=31218\&alias=sysbibli>. Acesso em: 10 jan. 2007.

(2003). Convenção para a salvaguarda do patrimônio cultural imaterial. UNESCO. Disponivel em:<http://unesdoc.unesco.org/images/0013/001325/132540s.pdf>. Acesso em: 15 jan. 2007.

ORGANIZAÇÃO DAS NAÇÕES UNIDAS PARA A EDUCAÇÃO, A CIÊNCIA E A CULTURA (2007). Disponivel em:<http://www.unesco.org.br/>. Acesso em: 5 jan. 2007.

PASK, G. (1973). Princípios de aprendizagem e de controle. In: EPSTEIN, I. (0rg.). Cibernética e comunicação. São Paulo: Cultrix. p.180-190. 
PLAN de alfabetización tecnológica de extremadura. (2004). Junta de Extremadura: Consejería de Educación, Ciencia y Tecnología.

PRATSCHKE A.; BORTOLUCCI, A.M.P.C.S.; COSTA, L.S.F. (2006). Pinhal digital: uma experiência transdisciplinar. In: KURI, N.P.; SILVA, A.N.R. (Ed.). 0 Ensino no campus de São Carlos: inovações e inovadores. São Carlos: CETEPE/EESC/USP. p.67-76.

PRATSCHKE, A. (2002). Entre mnemo e locus: arquitetura de espaços virtuais, construção de espaços mentais. 162p. Tese (Doutorado) - Instituto de Ciências Matemáticas de São Carlos, Universidade de São Carlos, São Carlos, 2002.

PRATSCHKE, A. (2004). Pinhal digital, estrutura mnemônica e processos multimídia nas fazendas de café: história, arquitetura e tecnologia. São Carlos: EESC/USP.

PRATSCHKE, A.; TRAMONTANO, M.; MOREIRA, E. (2000). Designer Wanted! : interface usuário-computador, o design de um diálogo. In: CONGRESSO IBERO AMERICANO DE GRÁFICA DIGITAL, 4., 2000, Rio de Janeiro. Rio de Janeiro: UFRJ.

PRATSCHKE, A.; SANTIAGO, R. P.(2006). Olhares múltiplos, ou como conceber um espaço de conhecimento para a cidade de São Carlos. In: CONGRESO IBEROAMERICANO DE GRÁFICA DIGITAL, 10., 2006, Santiago de Chile. Santiago: Sigradi y Universidad de Chile. v.1, p.377-380.

RABAÇA, C.; BARBOSA, G. (1998). Dicionário de comunicação. São Paulo: Ática.

RADCLIFFE-BROWN, A. (1989). Estrutura e função nas sociedades primitivas. Lisboa: Ed. 70 .

REDE PIPA MÓVEL (2006). Cidade do conhecimento. Disponível em:<http://www.cidade.usp.br/pipamovel>. Acesso em: 19 jan. 2006.

REDE PIPA SABE (2006). Cidade do conhecimento. Disponível em:<http://www.cidade.usp.br/pipas. Acesso em: 19 jan. 2006.

SAMPAIO, I.M. (2007). Teorias da comunicação. Campinas: Ed.UNICAMP.

SILVEIRA, S. (2001). Exclusão digital: a miséria па егa da informação. São Paulo: Perseu Abramo.

SIMMEL, G. (1988). Le Concept et la tragédie de la culture. In: La Tragédie de la culture et autres essais. Tradução de Francisco Coelho dos Santos. Paris: Petite Bibliothèque Rivages. p.34-67.

SMOLKA, A. (2000). A Memória em questão: uma perspectiva histórico-cultural. Educação Social, Campinas, v.21, n.71. Disponível em: <http://wWw.scielo.br/scielo.php?script=sci_arttext\&pid=S0101$73302000000200008 \& \operatorname{lng}=e s \& n \Gamma \mathrm{m}=\mathrm{is} 0>$. Acesso em: 9 out. 2006. 
SPILLER, N. (1998). Digital dreams: architecture and the new alchemic technologies. London: [s.n.].

TRUZZI, 0. (1986). Café e indústria: São Carlos 1850-1950. São Carlos: EdUFSCar.

VANSINA, J. (1987). Los Archivos, la historia, y la tradición orales. Disponível em: < unesdoc.unesco.org/images/0006/000687/068747so.pdf>. Acessado em: 11 mai. 2006

WIENER, N. (1954). Cibernética ou controle e comunicação no animal e na máquina. São Paulo: Polígono.

ZUMTHOR, P. (2001). A Letra e a voz: a "literatura" medieval. São Paulo: Companhia das Letras. 


\section{Iconografia}


1.1 Diagrama próprio sobre as classificações do patrimônio cultural.

1.2 Diagrama próprio sobre comunicação entre emissor е гесерtor.

2.1 Diagrama próprio sobre os diálogos e discursos em Flusser.

2.2 Diagrama próprio sobre reconfiguração de práticas comunicativas.

2.3 FERREIRA, M. A proposal for a collaborative environment for the early stages of product design. São Carlos: EESC-USP, 2005.

2.4 Rede Pipa Sabe. Disponível em: <www.cidade.usp.br/pipa/>.

2.5 Vatican Museums. Disponível em:

<http://mv.vatican.va/3_EN/pages/CSN/CSN_Volta.html>.

2.6 The Digital Michelangelo Davi. Disponivel em: 75 <http://graphics.stanford.edu/projects/mich/>. 16\&page $=6>$.

3.1 Fazenda Pinhal, pintura de Benedito Calixto. Disponível em: <http://www.saplei.eesc.usp.br/pinhaldigital/>. 
3.4 Levantamentos PinhalDigital 4.

3.5 Registros PinhalDigital 1.

3.6 Levantamentos e registros PinhalDigital 1, 2, 3 e 4.

3.7 Interface do curso PinhalDigital. Disponível em: <http://www.saplei.eesc.usp.br/pinhaldigital/>.

3.8-3.11 Proposta de interface durante PinhalDigital 3.

3.12 Registros PinhalDigital 3.

3.13 Diagrama próprio sobre ргocesso colaborativo de design.

3.14 Escola do Futuro. Disponivel em: <http://www.saocarlos.sp.gov.br>.

3.15 Diagrama próprio sobre interface colaborativa.

3.16 Diagrama próprio sobre navegação na interface PinhalDigital.

3.17 Registros PinhalDigital 3.

3.18 Diagrama próprio sobre relação cibernética entre mapa e †еггitório 119 na digitalização da Tulha. 


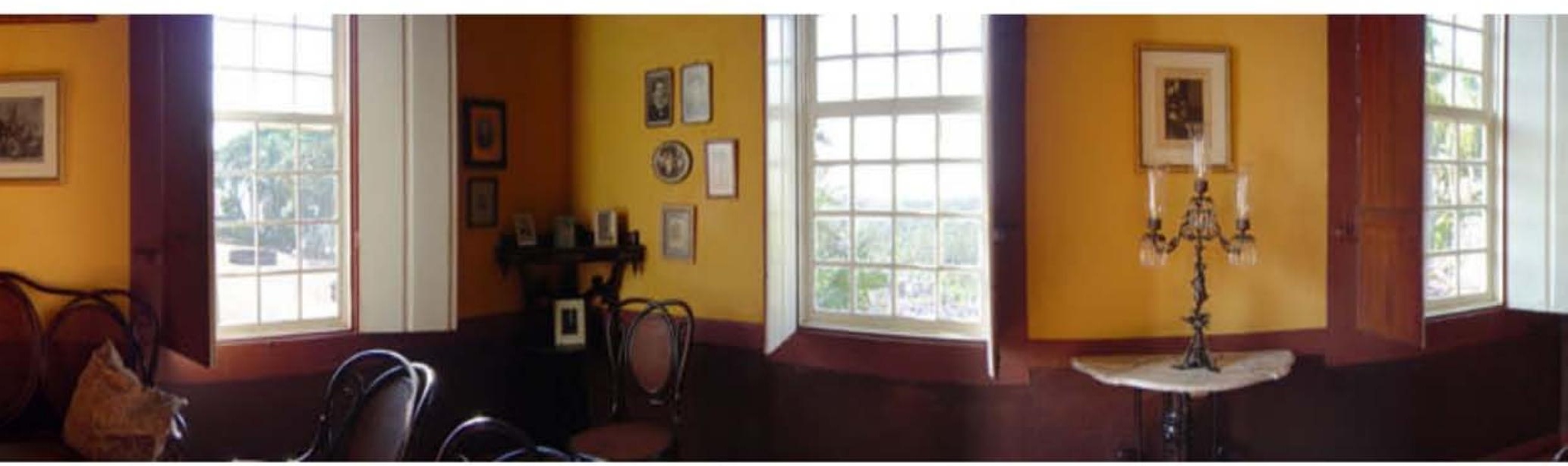

nomadsusp - núcleo de estudos de habitares interativos 